$D R 1026$

\title{
Hábito alimentar de Aedes aegypti e Culex quinquefasciatus e sua implicação na capacidade reprodutiva
}

Juliana Telles de Deus

Tese apresentada ao programa de pósgraduação na área de concentração de Saúde Pública da Faculdade de Saúde Pública da Universidade de São Paulo para obtenção do título de Doutor em Saúde Pública.

Área de concentração: Epidemiologia

Orientadora: Profạ. Dra. Iná Kakitani.

São Paulo 2011

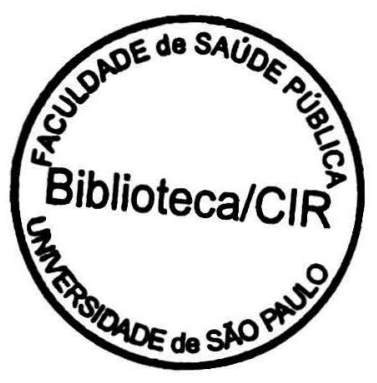


É expressamente proibida a comercialização deste documento, tanto na sua forma impressa como eletrônica. Sua reprodução total ou parcial é permitida exclusivamente para fins acadêmicos e científicos, desde que na reprodução figure a identificação do autor, título, instituição e ano da tese.

$$
52739 / 2011
$$


À minha mãe, Lídice Ao papai, Newton Ao meu irmão, Ricardo

Por Tudo

Ao afilhado querido, Antônio

Pelo que virá 


\section{AGRADECIMENTOS}

À professora Dra. Iná Kakitani pela orientação por todos esses anos meu agradecimento.

À Superintendência de Controle de Endemias, pelo apoio durante todo o desenvolvimento desse estudo.

Ao Hemocentro de Marília, sobretudo ao Marcel e equipe pela coleta de sangue.

À Faculdade de Medicina Veterinária da Universidade de Marília. Agradeço especialmente ao professor Fabio e seu auxiliar Nilson pela coleta de sangue dos animais

À Stela Maria Branquinho pela generosidade com seu conhecimento e ao abrir as portas do laboratório e até mesmo da sua casa.

À Regiane Tironi de Menezes, por horas de apoio e auxílio na análise estatística e discussão de todo o trabalho.

À Izilda Curado por seu olhar minucioso e competente.

À Helene Ueno, por compartilhar sua sabedoria e estar sempre perto quando foi preciso.

Ao Francisco Chiaravallotti, por dividir novos conhecimentos e por presentear o laboratório com alguns alimentadores artificiais.

À Maria Teresa Andrighetti e Maria de Lourdes Macoris pelas valiosas sugestōes na elaboração desse projeto em comum.

À Dinair, pelo primeiro alimentador artificial e amizade.

Aos veterinários Lupércio Garrido e Melissa por me atenderem tão prontamente na aquisição de sangue canino.

Ao queridos Celso, Fernanda Lé e Frederico, pelas membranas utilizadas nos alimentadores.

À Ana Paula Araújo, Alice Varjal pelo fornecimento das jangadas de Culex quinquefasciatus e preciosas dicas sobre sua criação. 
À Priscila Bochi, minha primeira aprimoranda e meu orgulho.

À Rosa Maria Tubaki pelo apoio.

Aos aprimorandos, meu agradecimento: Fernanda Cerone, Marcelo Rigueti, (maceradores de mosquitos de plantão).

Agradeço também ao Felipe Navarro, pela adaptação do mapa de Marília.

Ao Lucas por horas de trabalho e dedicação.

Ao Mário César Marques e Jane Bochi pelo constante incentivo.

Aos queridos que estão, ou passaram pelo Laboratório de Entomologia Aplicada da SUCEN de Marília: Elizângela, Terume, Elenice, Tânia, Neide, Ellen, Vanessa, Karina, Eliziane, Danilo, Sueli e Karen.

Agradeço também ao pessoal de campo da SUCEN de Marília: Vilson, Fantin, Carlos, Virgílio, Leonardo, Eloi, Cido.

À mamis pelas palavras certas e por ser o meu porto seguro. Obrigada mãe.

Ao Ricardo Telles de Deus e Adriana Pachione de Deus, pessoas que admiro o meu agradecimento.

Aos amigos da vida: Anderson, Alexandro, Camila Mugnai, Cássia, Cintia, Claudia Volpato, Gil, Gilberto Rossi, Izac, Kátia, Luciana Crê, Maira, Márcia Gutierrez, Márcio Vitielo, Priscila Mugnai, Thais, Silvana Mugnai.

Ao Eduardo Leme pelas palavras carinhosas e injeção de ânimo.

A todos os amigos que não foram aqui citados, mas que também foram importantes. 
Telles de Deus J. Hábito alimentar de Aedes aegypti e Culex quinquefasciatus e sua implicação na capacidade reprodutiva [tese de doutorado]. São Paulo: Faculdade de Saúde Pública da USP; 2011.

\section{RESUMO}

O estudo de hábito alimentar de espécies vetoras de doenças, ou potencialmente vetoras, indica os organismos envolvidos na transmissão e manutenção das doenças. Com a expansão de áreas urbanas e consequente aglomeração humana, como acontece no município de Marília, criou-se ambiente propício para a criação de mosquitos adaptados à essa situação. Esse trabalho teve por objetivo caracterizar o hábito alimentar de culicídeos capturados em área urbana do município de Marília e relacionar com o nível socioeconômico. A técnica utilizada para a identificação do hábito alimentar foi o ELISA (Enzyme Linked Immunosorbent Assay) considerando quatro hospedeiros (humano, cão, ave e roedor). Entre as espécies coletadas com maior frequência estavam os Aedes aegypti e Culex quinquefasciatus. Em laboratório foram testados os aspectos da capacidade reprodutiva para fêmeas dessas espécies, alimentadas artificialmente com sangue dos mesmos hospedeiros observados em campo. As espécies coexistem em toda a área mesmo em diferentes níveis socioeconômicos. A não concorrência pode ser explicada por apresentarem perfis hematofágicos distintos. Diferentemente do Ae. aegypti, o Cx. quinquefasciatus é espécie eclética quanto as fontes de hematofagia, no entanto apresentou maior frequência de repastos sanguíneos em roedores. Os Ae. aegypti se mostraram essencialmente antropofílicos.

Palavras chaves: hábito alimentar, Aedes aegypti, Culex quinquefasciatus. 
Telles de Deus J. Hábito alimentar de Aedes aegypti e Culex quinquefasciatus e sua implicação na capacidade reprodutiva./ Feeding habits of Aedes aegypti and Culex quinquefasciatus and its implications on the reproductive capacity [thesis]. São Paulo: Faculdade de Saúde Pública da Universidade de São Paulo; 2011.

\section{ABSTRACT}

The study of the feeding habits of vectors diseases species, or potentially vectors species, indicates the organisms involved in the maintenance and transmission of diseases. With the expansion of urban areas and consequent overcrowding, as occurs in Marilia city, an adapted environment for breeding mosquitoes was created. This study aimed to characterize the feeding habits of mosquitoes captured in urban region of Marilia and correlate with socioeconomic status. ELISA (Enzyme Linked Immunosorbent Assay) was the technique used to identify the mosquitoes feeding habits, considering four hosts (human, dog, bird and rodent). The most frequently collected species were Aedes aegypti and Culex quinquefasciatus. Aspects of reproductive capacity in females of these species were tested in laboratory through artificially feeding, with blood of the field observed hosts. The mosquitoes species coexist in the whole area, even in different socioeconomic levels. The absence of competition can be explained by differences in hematophagous profiles.

Although $C x$. quinquefasciatus is an eclectic specie in blood sources, in opposite of Ae. aegypti, a high frequency of biting in rodents was observed. Ae. aegypti showed a mainly anthropophilic biting activity.

Keywords: feeding habits, Aedes aegypti, Culex quinquefasciatus. 


\section{ÍNDICE}

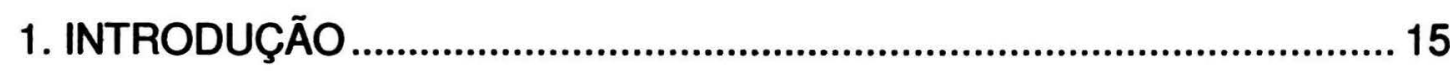

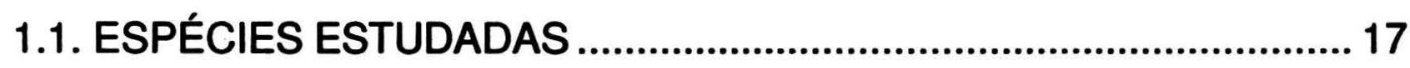

1.1.1. Aedes aegypti, Linnaeu, 1762.................................................. 17

1.1.2. Culex (Culex) quinquefasciatus, Say, 1823 ............................... 19

1.2. HÁBITO ALIMENTAR DE CULICÍDEOS ......................................... 21

1.2.1. Determinação de fonte alimentar de insetos hematófagos ......... 22

1.3. ESPAÇO URBANO E ANÁLISE SOCIOECONÔMICA........................24

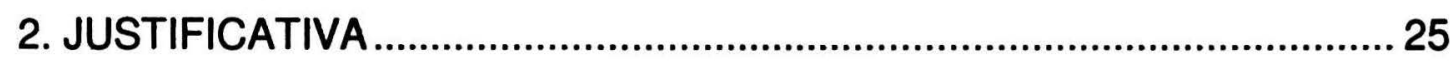

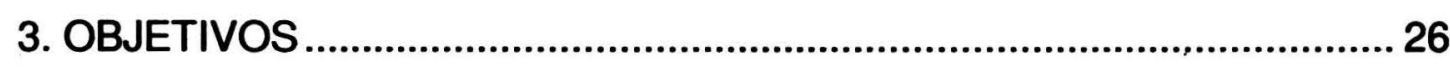

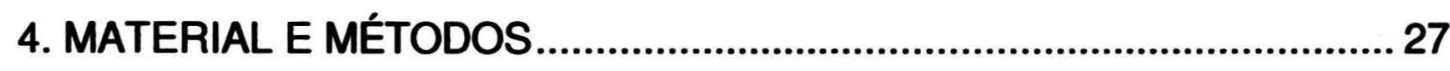

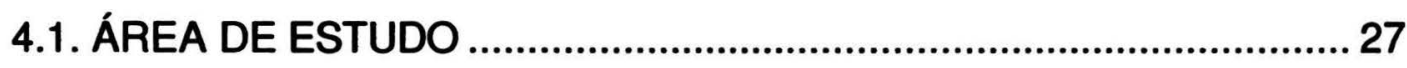

4.2. DELINEAMENTO EXPERIMENTAL ................................................ 30

4.3. HÁBITO ALIMENTAR DE FÊMEAS COLETADAS EM CAMPO ........30

4.3.1. Técnica de captura.................................................................. 30

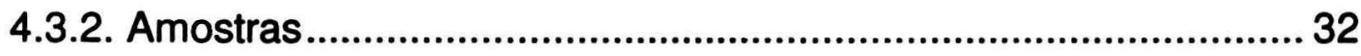

4.3.3. Avaliação do hábito alimentar através do teste ELISA (Enzyme Linked Immunosorbent Assay).......................................................... 33

4.3.4. Relação da fonte alimentar observada com aspectos socioeconômicos e climáticos das áreas onde os insetos foram coletados.

4.4. AVALIAÇÃO DA CAPACIDADE REPRODUTIVA DOS CULICÍDEOS EM LABORATÓRIO............................................................................. 41

4.4.1 Montagem do experimento para fornecimento de repasto sanguíneo.

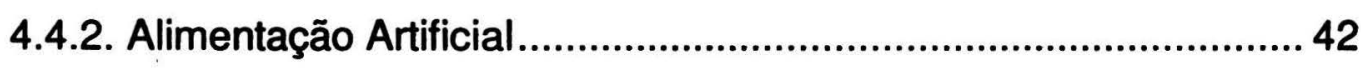

4.4.3. Criação dos ovos obtidos em cada tipo de repasto sanguíneo... 44

4.4.4. Parâmetros Observados .45 


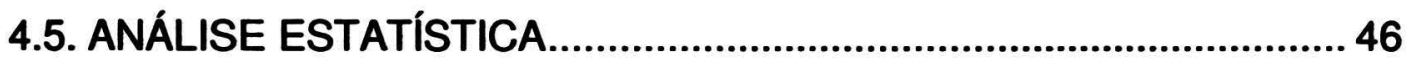

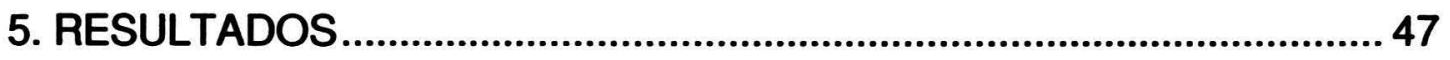

5.1. HÁBITO ALIMENTAR DE FÊMEAS COLETADAS EM CAMPO ........47

5.1.1. Fonte alimentar e aspectos socioeconômicos das áreas onde os insetos foram coletados. ........................................................................ 51

5.2. AVALIAÇÃO DA CAPACIDADE REPRODUTIVA EM LABORATÓRIO 56

5.2.1. Número de ovos postos por fêmeas de Ae. aegypti segundo repasto sanguíneo. 56

5.2.2. Média de ovos postos por fêmeas de $A e$. aegypti alimentadas com sangue humano 58

5.2.3. Fêmeas de Ae. aegypti alimentadas com sangue de cão 59

5.2.4. Fêmeas de Ae. aegypti alimentadas com sangue de Galinha ....60

5.2.5. Oviposição de fêmeas de $C x$. quinquefasciatus. 62

5.2.6. Fêmeas de $\mathrm{Cx}$. quinquefasciatus alimentadas com sangue humano 63

5.2.7. Fêmeas de $C x$. quinquefasciatus alimentadas com sangue de cão. 64

5.2.8. Fêmeas de $C x$. quinquefasciatus alimentadas após repasto com sangue de galinha 65

5.2.9. Fêmeas de $C x$. quinquefasciatus alimentadas com sangue roedor 66

5.3. Observação do desenvolvimento de imaturos a partir de ovos (F1) de fêmeas de Ae. aegypti alimentadas com sangue humano, de cão e de galinha 67

5.4. Observação do desenvolvimento de imaturos a partir de ovos (F1) provenientes de fêmeas de $C x$. quinquefasciatus alimentadas com sangue humano, de galinha e de roedor 72

6. DISCUSSÃO 79 
6.1. IDENTIFICAÇÃO DO HÁBITO ALIMENTAR PELO ELISA DE FÊMEAS COLETADAS EM CAMPO ….................................................. 79

6.2. FONTE ALIMENTAR OBSERVADA E ASPECTOS SOCIOECONÔMICOS DAS ÁREAS E CONDIÇÕES DAS CASAS.......... 83

6.3. ASPECTOS DA CAPACIDADE REPRODUTIVA …......................... 85

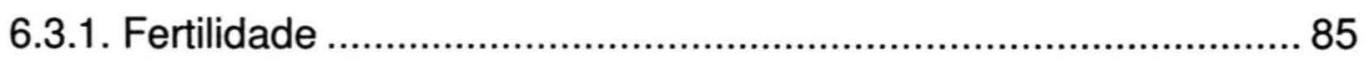

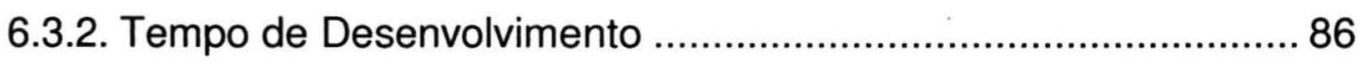

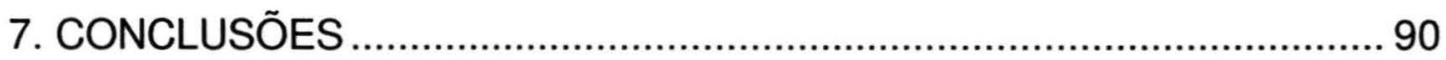

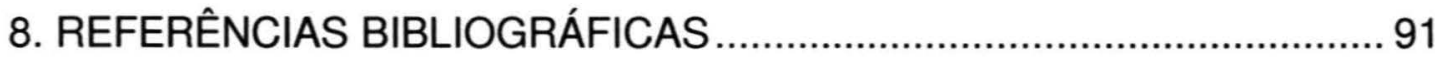

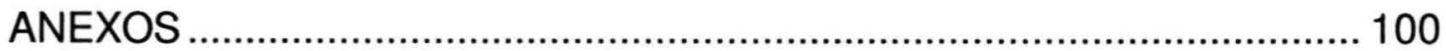

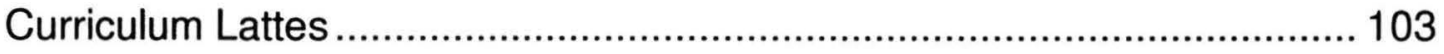




\section{LISTA DE FIGURAS}

Figura 1 - Localização do município de Marília - SP. Mapa adaptado do Relatório de Recursos hídricos das Bacias dos Rios Aguapeí/Peixe, 1997. 29 Figura 2 - Captura de mosquitos adultos no intra domicílio (A) e peridomicílio (B); acondicionamento dos mosquitos capturados (C) e preenchimento do boletim (D). Marília/SP, abril, 2009............................... 31

Figura 3 - A) fêmea em eppendor ${ }^{\text {; }}$; B) trituração da fêmea em PBS; C) amostra pronta para ser congelada.

Figura 4 - Execução do teste ELISA para avaliação do hábito alimentar. Laboratório de Simulídeos/SUCEN, maio, 2009. .36

Figura 5 - Modelo de alimentador artificial sobre gaiola. 42

Figura 6 - Bacias de criação para a observação do tempo de desenvolvimento de culicídeos. Laboratório de Entomologia Aplicada/SUCEN/Marilia, SP. Ago/2010.

Figura 7 - Percentual de fêmeas de Ae. aegypti e $C x$. quinquefasciatus alimentadas que realizaram um ou mais repastos.

Figura 8 - Percentual de fêmeas de Ae. aegypti e Cx. quinquefasciatus que realizaram repasto único em diferentes hospedeiros. 49

Figura 9 - Percentual de repastos múltiplos realizados por fêmeas de Aedes aegypti e Culex quinquefasciatus em um dos quatro hospedeiros testados: humano $(H)$, cão $(C)$, galinha $(G)$ e roedor $(R)$.

Figura 10 - Mapa da área urbana do município de Marília, SP apresentando os setores censitários segundo nível socioeconômico, 2000. .52

Figura 11 - Análise de correspondência das variáveis: tipo de vetor (Ae. aegypti e Cx. quinquefasciatus) e hábito alimentar. 55

Figura 12 - Análise de correspondência das variáveis: espécie de mosquito (Ae. aegypti e Cx. quinquefasciatus), hábito alimentar, índice de condição de casa (ICC), local de encontro na residência (INT e PER), estação do ano, período seco ou chuvoso, temperaturas mínima, média e máxima e umidade média.

Figura 13 - Média de ovos postos por fêmeas de Ae. aegypti após repasto sanguíneo de sangue humano, de cão, de galinha e de rato. 
Figura 14 - Média de ovos colocados por fêmea de Ae. aegypti após repasto sanguíneo humano e percentual de sobrevivência das mesmas. .58

Figura 15 - Média de ovos colocados por fêmea de Ae. aegypti após repasto sanguíneo de cão e percentual de sobrevivência das mesmas. 59 Figura 16 - Média de ovos colocados por fêmea de Ae. aegypti após repasto sanguíneo de galinha e percentual de sobrevivência das mesmas. 60 Figura 17 - Média de ovos colocados por fêmea de Ae. aegypti após repasto sanguíneo ,de roedor e percentual de sobrevivência das mesmas 61 Figura 18 - Média de ovos postos por fêmeas de Cx. quinquefasciatus após repasto sanguíneo humano, de cão, de galinha e roedor.

Figura 19 - Média de ovos colocados por fêmea de $C x$. quinquefasciatus após repasto sanguíneo humano e percentual de sobrevivência das mesmas.

Figura 20 - Média de ovos colocados por fêmea de $C x$. quinquefasciatus após repasto sanguíneo de cão e percentual de sobrevivência das mesmas.

Figura 21 - Média de ovos colocados por fêmea de $C x$. quinquefasciatus após repasto sanguíneo de galinha e percentual de sobrevivência das mesmas. 65

Figura 22 - Média de ovos colocados por fêmea de $C x$. quinquefasciatus após repasto sanguíneo com sangue de roedor e percentual de sobrevivência das mesmas. 66 Figura 23 - Distribuição percentual da duração do período de ovo à pupa de espécimes de Ae. aegypti segundo fonte alimentar das fêmeas geradoras humano, cão e ave. 68

Figura 24 - Percentual de ovos de Ae. aegypti, alimentadas com sangue humano, que se desenvolveram até o estágio de pupa

Figura 25 - Percentual de ovos de Ae. aegypti, alimentadas com sangue de cão, que se desenvolveram até o estágio de pupa. 70 Figura 26 - Percentual de ovos de Ae. aegypti, alimentadas com sangue de galinha, que se desenvolveram até o estágio de pupa. 71 
Figura 27 - Distribuição percentual da duração do período de ovo à pupa de espécimes de $C x$. quinquefasciatus segundo fonte alimentar das fêmeas geradoras A) humano, B) cão e C) ave.................................................... 73 Figura 28 - Percentual de ovos de fêmeas de Cx. quinquefasciatus, alimentadas com sangue humano, que se desenvolveram até o estágio de pupa. .74

Figura 29 - Percentual de ovos de fêmeas de Cx. quinquefasciatus, alimentadas com sangue de cão, que se desenvolveram até o estágio de pupa. .75

Figura 30 - Percentual de ovos de fêmeas de $C x$. quinquefasciatus, alimentadas com sangue de galinha, que se desenvolveram até o estágio de pupa. 76

Figura 31 - Percentual de ovos de fêmeas de Cx. quinquefasciatus, alimentadas com sangue de roedor, que se desenvolveram até o estadio de pupa. 77 


\section{LISTA DE TABELAS}

Tabela 1 - Variáveis climáticas (temperatura em graus Celsius $\left({ }^{\circ} \mathrm{C}\right)$ e umidade relativa do ar) divididas em três categorias. 38

Tabela 2 Número de fêmeas de Ae. aegypti e Cx. quinquefasciatus examinadas segundo local de coleta, fonte alimentar, estação do ano, período e temperatura.

Tabela 3 - Número de fêmeas coletadas que realizaram repasto sanguíneo em um dos hospedeiros testados (homem, cão, ave e/ou roedor). Marília, SP, junho de 2007 a agosto de 2008.

Tabela 4 - Relação entre nível socioeconômico e repasto sanguíneo realizado por fêmeas de Ae. aegypti em humano (HU) e animal (AN). 53 Tabela 5 - Relação entre nível socioeconômico e repasto sanguíneo realizado por fêmeas de $C x$. quinquefasciatus em humano $(H U)$ e animal (AN). 53

Tabela 6 - Relação entre local de captura de Ae. aegypti - Intra (INT) e Peridomicílio (PER) e área socioeconômica. 54

Tabela 7 - Relação entre local de captura de $C x$. quinquefasciatus - Intra (INT) e Peri-domicílio (PER) e área socioeconômica. 54

\section{LISTA DE QUADROS}

Quadro 1 - Critério utilizado para avaliação das casas para determinar o ICC (Índice de Condição de Casa)

Quadro 2. Gaiolas com fêmeas de culicídeos separadas por espécie e sangue de hospedeiro do qual se alimentaram. 


\section{INTRODUÇÃO}

Os Culicidae são conhecidos pelo incômodo que causam ao exercer a hematofagia, e é com esse comportamento que também se estabelecem como organismos transmissores de infecçōes ao homem e animais. Entre as mais de três mil espécies de culicídeos conhecidas, algumas estreitaram relações com $\circ$ homem $e$ animais domesticados, o que propiciou a disseminação de doenças como a malária, a dengue e as filarioses (EDMAN, 2003).

As infecções causadas por vírus veiculados por artrópodes a hospedeiros vertebrados são chamadas de arboviroses, e são, na maior parte das vezes, zoonoses. Os culicídeos desempenham papel epidemiológico importante na transmissão dessas infecções ao atingirem a população humana. Algumas arboviroses mantêm-se em ciclo silvestre, sendo que o homem pode ser atingido ocasionalmente, gerando casos isolados. Outras podem assumir caráter rural ou urbano, onde o homem pode ser considerado fonte de infecção de doenças. A relação hospedeirovetor-homem potencialmente favorece 0 surgimento das arboviroses tornarem-se infecções humanas (FORATTINI, 2002).

Dentre as arboviroses cujos vetores são culicídeos, a dengue e a febre amarela destacam-se como problemas de saúde pública no Brasil. Adicionalmente, são arboviroses relevantes algumas encefalites que também representam significantes agravos de saúde pública, considerando que atingem animais domesticados (FORATTINI, 2002).

Além de arboviroses, os culicídeos são responsáveis pela transmissão de filarioses, infestações causadas por helmintos nematódeos que utilizam os artrópodes como hospedeiros intermediários e os vertebrados como hospedeiros definitivos. Outra parasitose de grande relevância veiculada por mosquitos anofelíneos é a malária, cujos agentes são protozoários do gênero Plasmodium.

A alimentação basal da maior parte dos culicídeos adultos consiste no repasto de açúcares para ambos os sexos. Essa alimentação energética 
Ihes permite desempenhar funções como voar e copular. Já para o desenvolvimento dos ovos os nutrientes necessários são obtidos através de repasto sanguíneo, realizado pelas fêmeas.

A fonte de alimentação dos culicídeos dependerá do ambiente em que se encontram e da densidade de hospedeiros disponíveis (KELLY, 2001; FORATTINI, 2002). Mudanças no comportamento alimentar de mosquitos explicam-se pela pressão de seleção e a tentativa de adaptação para localizar, discriminar e obter sucesso frente a novos hospedeiros (EDMAN, 2003).

O desmatamento de florestas, substituídas por sociedades agrárias emergentes modificam cada vez mais o ecótopo dos criadouros de populações silvestres de mosquitos, desencadeando o processo de domesticação. Algumas espécies de mosquito podem se beneficiar do ambiente humano transformado e encontrar condições ideais de proliferação em potenciais criadouros e oferta de alimentação sangüínea (DANIEL e KINGSOLVER, 1983). É desta forma que determinadas espécies de culicídeos, como o Aedes aegypti e o Culex quiquefasciatus, se tornaram próximas do homem e dos animais, situação propícia para a transmissão de patógenos. 


\subsection{ESPÉCIES ESTUDADAS}

\subsubsection{Aedes aegypti, Linnaeu, 1762}

Classificação: Classe Insecta, Família Culicidae, Subfamília Culicinae, Tribo Aedini, gênero Aedes, subgênero Stegomyia.

Os Ae. aegypti adultos possuem coloração escura que varia do marrom para o negro, com destaque em seu escudo com escamas prateadas em forma de "lira". O tórax possui escamas claras e escuras e as pernas apresentam aspecto listrado (FORATTINI,2002; CONSOLI E LOURENÇO DE OLIVEIRA, 1994).

Os criadouros típicos são os recipientes artificiais como latas, pneus, vasos de plantas, cisternas, piscinas entre outros. Por resistirem à dessecação, os ovos são frequentemente colocados nas paredes dos recipientes de forma que eclodirão quando esses forem expostos à chuva. Assim, a maior densidade populacional da espécie está relacionada a períodos chuvosos.

Procedente da região afrotropical, esse mosquito é tido classicamente como tropical e subtropical. Possui ampla distribuição nas Américas onde é considerado essencialmente domiciliado e frequenta a habitação humana para o abrigo e hematofagia das fêmeas.

A espécie é responsável pela transmissão do vírus da Dengue, que nas Américas se expandiu durante a segunda metade do século $X X$ e da febre amarela urbana nas Américas.

Desde 1942 não se registra no Brasil surto epidêmico de Febre Amarela urbana. No entanto, para que aconteça a transmissão urbana natural de febre amarela, é necessária a existência de pelo menos um caso de portador da forma silvestre proveniente de área endêmica brasileira ou de um caso importado de outro país em área infestada pelo Ae. aegypti (SUCEN, 2010)'.

\footnotetext{
1 SUCEN - Superintendência de Controle de Endemias. [acesso em 19 dez 2010]. Disponivel em: http://www.sucen.sp.gov.br/
} 
Segundo o Boletim de Atualização da Situação da Febre Amarela Silvestre no Brasil (MINISTÉRIO DA SAÚDE, 2009)', entre setembro de 2008 e setembro de 2009, foram notificados 274 casos humanos suspeitos de febre amarela silvestre (FAS), com 51 casos confirmados. Destes, 21 evoluíram para o óbito e a taxa de letalidade foi de 41\%. Segundo o Boletim Final Sobre a Situação da Febre Amarela Silvestre no estado de São Paulo (CVE, 2010) ${ }^{2}$, até o último dia do mês de dezembro de 2009, a situação epidemiológica da doença foi de 83 casos confirmados sendo que 11 evoluíram para óbito.

Foram confirmados, até a semana 26 de 2010 no Brasil, 482.284 casos da doença. $O$ número de casos graves da enfermidade no mesmo período foi de 9.688 e desses, 2.271 eram casos de Febre Hemorrágica do Dengue. Foram notificados 367 óbitos, o que representa um aumento de 67,6\% em relação ao mesmo período de 2009.

O Estado de São Paulo registrou, até a semana 26 de 2010, 187.460 casos confirmados da doença, sendo responsável por $39 \%$ dos casos confirmados no país, desses 911 ocorreram no município de Marília (CVE, 2010) ${ }^{3}$. Em nota técnica ${ }^{4}$, o Ministério da Saúde informou que o sorotipo viral DENV-4 foi isolado no Brasil no estado de Roraima em 2010, o que não acontecia há 28 anos. Apesar disso é ressaltado na nota que a maior probabilidade de epidemia é pelo sorotipo DENV-1.

1 Ministério da Saúde. Boletim de Atualização: Situação Epidemiológica da Febre Amarela Silvestre no Brasil. [acesso em 19 dez 2010]. Disponivel em: http://portal.saude.gov.br/portal/arquivos/pdf/boletim_febre_amarela_09_12_09.pdf

${ }^{2}$ CVE - Centro de Vigilância Epidemiológica. Boletim Final Sobre a Situação da Febre Amarela Silvestre no Estado de São Paulo. [homepage na internet]. São Paulo. [acesso em 19 dez 2010]. Disponivel em: ftp://ttp.cve.saude.sp.gov.br/doc_tec/ZOO/Boletim_FASP171209.pdf

${ }^{3}$ CVE - Centro de Vigilância Epidemiológica. Dengue/dados. [homepage na internet]. São Paulo [acesso em 19 dez 2010]. Disponivel <http://www.cve.saude.sp.gov.br/htm/zoo/den10_import_autoc.htm>.

${ }^{4}$ Nota Técnica N. 118 / 2010 CGPNCD/DEVEP/SVS/MS [homepage na internet]. São Paulo [acesso em 19 dez 2010]. Disponivel em:

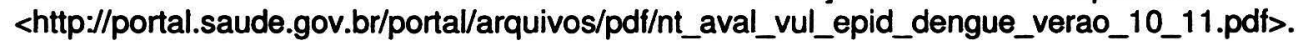


1.1.2. Culex (Culex) quinquefasciatus, Say, 1823

Classificação: Classe Insecta, Família Culicidae, Subfamília Culicinae,Tribo Culicini, gênero Culex, subgênero Culex.

Os $C x$. quinquefasciatus adultos possuem porte médio de coloração marrom claro e escuro, recoberto por escamas amarelo-douradas e tarsos escuros sem marcação clara. Apresentam escamas brancas no ápice dos palpos. Seu occipício é recoberto por escamas brancas forquilhadas em posição antero-central e escuras nas laterais e posteriores. Os tergitos possuem manchas brancas basais enquanto que os esternitos são recobertos por escamas brancas (FORATTINI, 2002; CONSOLI E LOURENÇO DE OLIVEIRA, 1994).

Os Cx. quinquefasciatus, distribuídos nas regiões tropicais e subtropicais, sendo que nas Américas estendem-se desde a área central e sul dos EUA até a Argentina (FORATTINI, 2002).

A espécie encontra-se totalmente adaptada aos costumes do homem, tanto no meio urbano como no rural. Suas formas imaturas são encontradas em diversos criadouros como depósitos artificiais, solo e recipientes com água rica em matéria orgânica, desenvolvendo-se inclusive em águas poluídas. Com o desenvolvimento das cidades e esgotos não tratados, esta espécie encontrou o habitat ideal para a sua proliferação, atingindo altas densidades (FORATTINI, 2002). São mais frequentes em meses quentes e chuvosos, época de maior oferta de criadouros com água, no entanto não há interrupção do seu ciclo durante todo o ano (CONSOLI E LOURENÇO DE OLIVEIRA, 1994).

As fêmeas de $C x$. quinquefasciatus são consideradas antropofílicas, no entanto podem mostrar certo grau de ecletismo quanto à preferência alimentar. Alguns autores ressaltam 0 hábito desses hematófagos de se alimentarem de aves e répteis. (FORATTINI et al., 1987; 2002; CASTEX et al., 1990). 
A espécie demonstrou ser vetor competente para alguns arbovírus causadores de encefalites, que constituem sério problema de saúde pública por apresentar múltipla origem e potencial para gerar epidemias (especialmente porque infectam animais domesticados).

A Febre do Nilo (FNO) é uma arbovirose causada pelo Vírus do Nilo Ocidental (VNO), que foi isolado pela primeira vez no distrito de West Nile, em Uganda, no ano de 1937. A doença se propaga por meio de aves em suas rotas migratórias e tem nos mosquitos do gênero Culex, os vetores mais eficientes desse arbovírus. Esses mosquitos possuem características antropofílicas e ornitofílicas e possuem sazonalidade, tendo maior presença em períodos quentes do ano.

O primeiro registro da FNO nas Américas foi em 1999, e em 2002, o vírus atingiu milhares de pessoas nos EUA, chegando-se notificar 9.388 casos com 264 óbitos em 2003 e 4.261 casos em 2006 e 174 óbitos em 2004. O vírus foi isolado na América Central em 2002 e em 2005 foram detectados anticorpos do vírus em cavalos na Colômbia e em 2006 na Venezuela (cavalos/aves) e Argentina (cavalos/humanos) (MINISTÉRIO DA SAÚDE, 2008).

A introdução desse vírus no Brasil preocupa as autoridades de Saúde Pública e, diante dessa possibilidade, as atividades de vigilância epidemiológica deverão se voltar tanto aos reservatórios quanto aos artrópodes vetores. No Brasil, o risco do $C x$. quinquefasciatus, tornar-se vetor desse vírus é potencializado pela sua frequência na maior parte dos centros urbanos, pela proximidade com o homem e elevada densidade (NATAL e UENO, 2004). Caso essa se torne doença emergente no país, será necessário o manejo integrado adequado de vetores, baseado no conhecimento bioecológico das espécies envolvidas na cadeia de transmissão da doença (NATAL e UENO, 2004).

\footnotetext{
'Ministério da Saúde. Febre do Nilo Ocidental. [homepage na internet]. Brasil. [acesso em 27 jan 2008]. Disponível em: <http://portal.saude.gov.br/portal/saude/visualizar_texto.cfm?idtxt=27015>.
} 
Esses mosquitos também são vetores associados às filarioses por Wuchereria bancrofti, endêmicas em estados do Norte e Nordeste do Brasil (ROCHA E FONTES, 1998). Pelo fato da hematofagia de $C x$. quinquefasciatus demorar até 4 minutos para se completar, esse período de contato entre fêmea e homem favorece a transmissão da filariose bancroftiana (CHADEE \& BEIER, 1996).

Outra parasitose importante veiculada por esses insetos são as dirofilarioses cujo agente etiológico é a Dirofilaria immitis comumente encontradas em cães e gatos. (FORATTINI, 2002).

\subsection{HÁBITO ALIMENTAR DE CULICÍDEOS}

A alimentação de mosquitos adultos é baseada em substâncias energéticas obtidas em néctar de flores, orvalho e frutas. Além disso, para a maior parte dos culicídeos, as fêmeas, além do repasto açucarado, também exercem a hematofagia, que é o hábito de sugar sangue.

Ao ingerir sangue as fêmeas se beneficiam de aminoácidos, que são fundamentais para o desenvolvimento embrionário, uma vez que farão parte do vitelo, sendo, dessa forma, importantes para a reprodução.

A preferência por determinado animal aparece mais em algumas espécies do que em outras e isso influencia todo o seu comportamento. Os mosquitos ditos antropofílicos se adaptam bem ao habitat humano e se domiciliaram. Os mosquitos que tem por hábito sugar o sangue de animais são considerados zoofílicos.

O estudo do hábito alimentar de espécies vetoras, ou potencialmente vetoras, de doenças pode indicar os possíveis vertebrados envolvidos no ciclo de transmissão e manutenção das mesmas. A caracterização do hábito alimentar permite avaliar epidemiologicamente o comportamento dos artrópodes e sua capacidade vetora (WEITZ, 1956, BOREHAM, 1972, FORATTINI et al., 1987). 
Vários são os fatores ambientais que influenciam o comportamento alimentar dos mosquitos, como a estação do ano e o microhabitat (NIEBYLSKI et al., 1994; CAMARGO-NEVES et al., 2007). Além disso, devem-se considerar outros fatores como: a capacidade intrínseca de cada espécie para localizar os hospedeiros e a densidade dos hospedeiros disponiveis, sejam eles autóctones ou introduzidos ao habitat. Tais informações contribuem para a melhor compreensão de algumas epizootias e epidemias veiculadas por mosquitos (FORATTINI et al., 1987).

Além do envolvimento nos ciclos de transmissão de doenças, a preferência alimentar de insetos hematófagos interfere na sua capacidade reprodutiva, uma vez que diferentes qualidades de nutrientes podem ser ingeridas. Espécies que frequentemente se alimentam de sangue humano se beneficiam desta síntese energética para o desenvolvimento de seus descendentes (reprodução e sobrevivência), o que explicaria o contato frequente e específico com o homem (HARRINGTON et al., 2001). Os mosquitos da espécie Ae. aegypti, mesmo na presença de outros hospedeiros como cães, roedores, e aves, tendem a buscar sangue humano para se alimentar (SCOTT et al., 1993, 2000).

\subsubsection{Determinação de fonte alimentar de insetos hematófagos}

Existem várias técnicas para identificação do hábito alimentar de insetos, dentre elas destacam-se: a reação de precipitina, a cristalização da hemoglobina, as reações de aglutinação, o teste de hemaglutinação passiva e o método imunohistoquímico de imunosflorescência. Alguns testes mostraram-se, no entanto, pouco específicos ou sensíveis.

A técnica mais utilizada para a identificação de hospedeiros sanguíneos em insetos hematófagos foi a reação de precipitina (TEMPELIS, 1975; EDRISSIAN et al., 1982; BEIER, 1988). Esse teste consiste em uma reação direta do sangue ingerido, suspenso em um diluente, com um antisoro (TEMPELIS, 1975). Entretanto, essa técnica oferece várias limitações, principalmente a baixa sensibilidade e a necessidade de grandes 
quantidades de amostra, fato que inviabiliza sua utilização com insetos de pequeno porte.

O teste imunoenzimático ELISA foi desenvolvido inicialmente para diagnóstico de pacientes amarílicos. $O$ termo foi utilizado primeiramente por Engvall e Perlmann em 1971, quando relataram o emprego de conjugados enzimáticos em imunoensaios (FERREIRA e ÁVILA, 2001). A técnica foi adaptada para o estudo do hábito alimentar em culicídeos (VOLLER et al., 1974). Edrissian et al. (1982) aplicaram a técnica em anofelinos e constataram que é uma técnica específica e sensivel para a detecção de pequena quantidade de sangue humano 24 horas após ingestão de sangue pelo mosquito. A técnica é mais sensível para mosquitos capturados recémalimentados - 12 horas para uma identificação positiva de $75 \%$ do sangue (BURKOT et al., 1981).

A técnica consiste num ensaio heterogêneo que detecta antígenos ou anticorpos através de uma coloração medida em absorbância por espectrofotômetro (BEIER, 1988). Existem alguns métodos para sua realização: o método direto, que é mais simples, rápido e permite que grande número de amostras sejam processadas (EDRISSIAN et al., 1985); o método indireto, mais complexo, requer um anti-soro para cada hospedeiro testado (BEIER, 1988); uma combinação do método direto com o indireto (LINTHICUM et al., 1985); ELISA "sanduíche" (SERVICE et al., 1986).

O teste ELISA também permite detectar repastos mistos (VICENTIN, 2007). A observação de múltiplos repastos pode ser explicada pela possível discordância gonotrófica da espécie e é importante informação para os estudos epidemiológicos.

O teste ELISA para hábito alimentar é baseado no conceito de que cada espécie de vertebrado possui uma ou mais proteínas do plasma, determinantes antigênicos, que são únicos para cada espécie. Portanto, a identificação de um repasto de sangue depende largamente da habilidade do anti-soro em reconhecer essas proteínas únicas do sangue do hospedeiro (RURANGIRWA et al., 1986). 
Técnicas moleculares, como a Reação de Polimerização em Cadeia (PCR), foram adaptadas à identificação das possíveis fontes alimentares de insetos vetores, dentre eles, os culicídeos (KENT E NORRIS, 2005; MOLAEI et al., 2008). A PCR que utiliza marcadores de genes mitocondriais, tais como o citocromo $b$, para detecção de hábito alimentar de vários vetores tem a vantagem destes estarem localizados no genoma mitocondrial (que não sofre recombinação), além da disponibilidade de sequências completas no "Genbank", que permite uma comparação extensa entre as espécies (PERKINS E SCHALL, 2002), apontando, por vezes, reservatórios não esperados (CHOW et al., 1993; HAOUAS et al., 2007).

\subsection{ESPAÇO URBANO E ANÁLISE SOCIOECONÔMICA}

O espaço urbano é organizado, segundo Milton Santos (1997), de modo heterogêneo, sendo produto e produtor de diferenças sociais e estabelecendo, dessa forma, condições diferenciadas para o desenvolvimento das populações humanas.

A visualização do espaço urbano dividido em setores censitários permite representar dados populacionais e socioeconômicos coletados de forma padronizada e com abrangência nacional. A estratificação de dados de diferentes níveis de agregação aponta as áreas com riscos desiguais para a ocorrência de doenças endêmicas (XIMENES et al., 1999).

A dispersão de vetores e de agravos pode ser facilitada ou não pela estrutura urbana assim como seus aspectos socioeconômicos. A categoria "lugar" não é mais considerada apenas a localização das ocorrências, passa a ser um dos principais elementos da análise da distribuição das doenças (BARCELLOS E BASTOS, 1996). 


\section{JUSTIFICATIVA}

A identificação do sangue ingerido por vetores hematófagos é importante no estudo da disseminação de antropozoonoses endêmicas e emergentes, pois fornece informações sobre os possíveis organismos envolvidos nos ciclos das doenças transmitidas por vetores biológicos.

Conhecer o hábito alimentar e suas implicações na capacidade reprodutiva nas espécies $A e$. aegypti e $C x$. quinquefasciatus pode fornecer um parâmetro de domiciliação importante para a vigilância e controle do dengue, febre amarela, febre do Nilo e outras arboviroses.

A observação em laboratório da capacidade reprodutiva de fêmeas de Ae. aegypti e Cx. quinquefasciatus, alimentadas sob diferentes fontes sanguíneas, auxiliará a compreensão de parâmetros de adaptação dessas espécies. 


\section{OBJETIVOS}

Objetivo geral: Caracterizar o hábito alimentar de culicídeos das espécies Ae. aegypti e $C x$. quinquefasciatus em área urbana e sua influência na capacidade reprodutiva dessas espécies considerando aspectos socioeconômicos.

Objetivos específicos

- Identificar o hábito alimentar de culicídeos capturados no município de Marília para quatro tipos de hospedeiros;

- Identificar a ocorrência de repastos múltiplos nos espécimes coletados;

- Relacionar a fonte alimentar observada com aspectos sócioeconômicos das áreas onde os insetos foram coletados;

- Relacionar a fonte alimentar observada com aspectos climáticos no momento da captura;

- Comparar em laboratório aspectos da capacidade reprodutiva (fertilidade, tempo de desenvolvimento) das duas espécies de culicídeos alimentadas com sangue humano, de cão, ave e roedor. 


\section{MATERIAL E MÉTODOS}

O estudo foi realizado no município de Marília pela disponibilidade de dados, facilidades de coletas entomológicas e também por ser representativa de uma cidade de médio porte do interior do Estado de São Paulo.

\section{1. ÁREA DE ESTUDO}

O município de Marília situa-se na região Centro Oeste Paulista, a $443 \mathrm{~km}$ da capital do Estado por rodovia (Figura 1). Possui aproximadamente 200 mil habitantes em uma área total de $1.194 \mathrm{~km}^{2}$, sendo $42 \mathrm{~km}^{2}$ de área urbana e $1.152 \mathrm{~km}^{2}$ de área rural, divididos em 263 setores censitários:

Segundo a Carta Climática do Estado de São Paulo (GODOY \& ORTOLANI, 1965), o clima da região é tropical de altitude (classificação climática de Köppen-Geiger (wa) com verão quente e inverno seco. A temperatura média do mês mais quente superior a $23^{\circ} \mathrm{C}$ e a do mês mais frio $15,2^{\circ} \mathrm{C}$. A precipitação pluviométrica média anual é $1.129 \mathrm{~mm}$, com deficiência hídrica anual da ordem de 50 a $80 \mathrm{~mm}$.

O perímetro urbano é dividido por águas dos Rios Peixe e Aguapeí. Algumas nascentes deságuam em córregos como Pombo, Barbosa, afluentes do Peixe, Palmital e Cascata afluentes do Tibiriçá. Outras nascentes encontram-se canalizadas ou estão expostas em áreas descuidadas. O DAEM (Departamento de Água e Esgoto de Marília) é o responsável pelo abastecimento da cidade, a partir de captações subterrâneas (poços profundos) e superficiais (Rio do Peixe, Barragens do

Marilia 2008. [homepage na internet]. Marília/SP [acesso em 27 jan 2008]. Disponivel em: <http://uww.marilia.sp.gov.br>. 
Arrependido e Cascata). O departamento atende 98,5\% dos domicílios para distribuição de água e $96,4 \%$ de coleta de esgoto (SEADE, 2007)*.

A cidade, centro comercial e de prestação de serviços, é sede de região administrativa com mais de $\mathbf{8 0 0}$ mil habitantes e pólo macro-regional do Centro-oeste do Estado. O mapa da cidade em alguns locais é recortado pela estrada de ferro, em outros pelos córregos, além de ser delimitado pelas vertentes dos vales. A paisagem urbana de Marília é constituída por contrastes onde se encontra remanescentes do cenário da colonização do início do século, com ruas estreitas no centro comercial e das antigas casas de madeira, aliado à novos bairros e loteamentos. Os Distritos industriais são implantados com rápida ocupação e atração de novos empreendimentos residenciais ao seu entorno (GENTILE E MARQUES, 2009).

Em dezembro de 1986 foi confirmada a reinfestação do município pelo Ae. aegypti No que diz respeito à dengue a primeira transmissão ocorreu em 1990, desde então a circulação do vírus tem ocorrido com níveis baixos de incidência (SVS, 2000)**.

\footnotetext{
* FUnDAÇÃo SISTEMA ESTADUAL DE ANÁLISE DE DADOS - SEADE. População e estatísticas vitais.|acesso em 25 jan 2011]. Disponivel em: http//unw.seade.sp.gov.br

* Secretaria de Vigilância em Saúde - SVS.[acesso em 27 jan 2011]. Disponivel em: http//uww.saude.gov.br
} 
Figura 1 - Localização do município de Marília - SP. Mapa adaptado do Relatório de Recursos hídricos das Bacias dos Rios Aguapeí/Peixe, 1997.

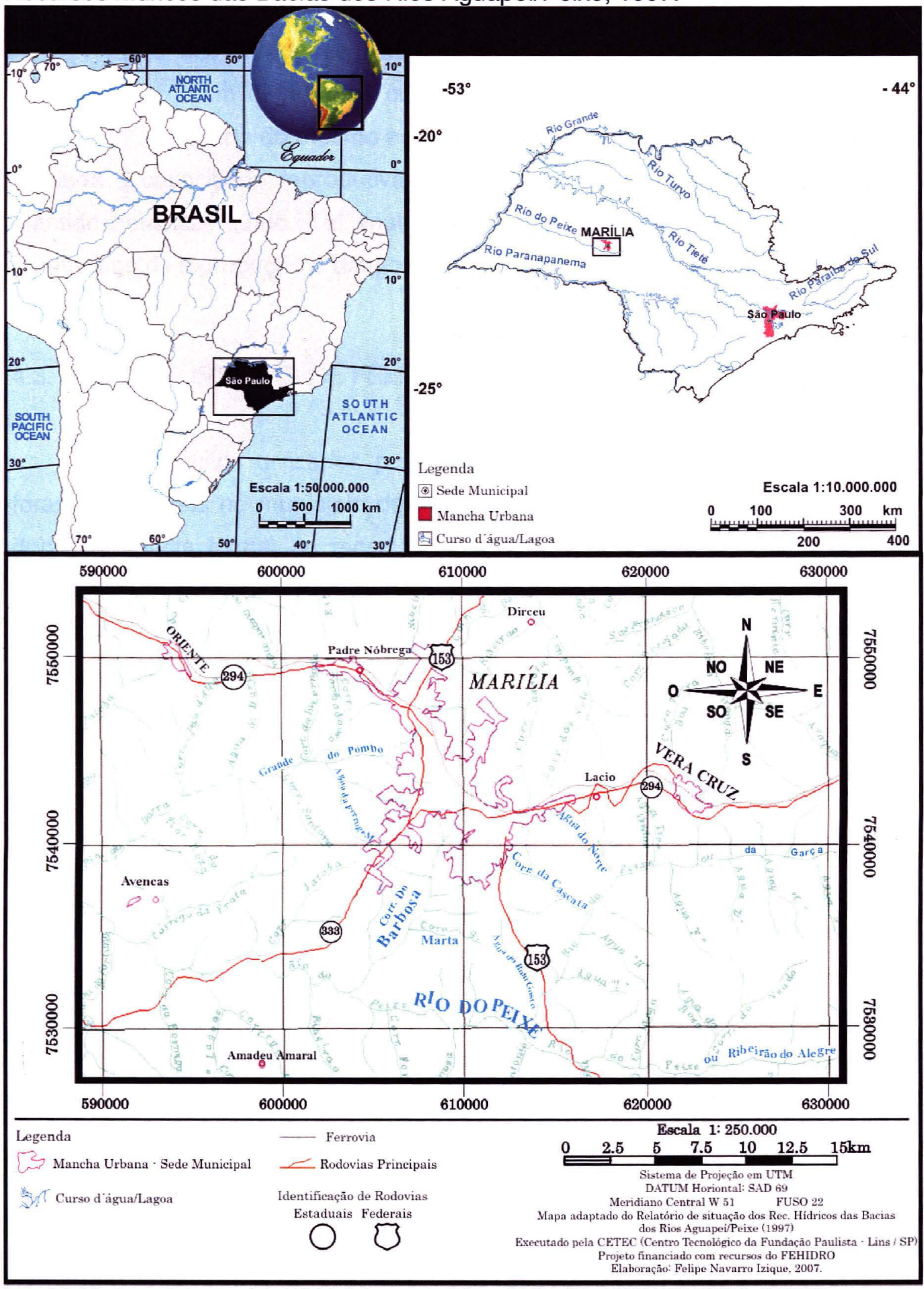

Fonte: link: http://www.sigrh.sp.gov.br/cgi-bin/sigrh_home_colegiado.exe?TEMA=RELATORIO\&COLEGIADO=CRH/CBHAP\&Iwgactw=489475 


\subsection{DELINEAMENTO EXPERIMENTAL}

Parte das atividades previstas para o estudo foi realizada em campo, onde foram capturados culicídeos adultos para análise do hábito alimentar. Outra parte do mesmo estudo foi experimental, a fim de que fosse avaliada a capacidade reprodutiva, de Ae. aegypti e Cx. quinquefasciatus mantidos em laboratório. Tal análise foi feita através de quantificação de parâmetros de reprodução e tempo de desenvolvimento de imaturos.

\subsection{HÁBITO ALIMENTAR DE FÊMEAS COLETADAS EM CAMPO}

Os mosquitos utilizados para a caracterização do hábito alimentar foram capturados no município de Marília em área urbana no intra e peridomicílio. Desta forma, os mosquitos encontravam-se em contato com a população humana e alguns animais domésticos. Os mosquitos coletados foram identificados até 0 nível de espécie. Todas as fêmeas foram separadas, mantidas secas em tubos com sílica gel enumerados.

\subsubsection{Técnica de captura}

As capturas dos adultos de culicídeos no intra-domicílio e no peridomicílio foram realizadas através de aspirador manual movido a bateria (NASCl, 1981), conforme metodologia preconizada pelo Centers of Disease Control (CLARK et al., 1994) modificado por Andrighetti et al. (2009). Os domicílios foram inspecionados por uma dupla de capturadores. Um deles atuava movendo objetos, cortinas, e móveis enquanto o segundo direciona o capturador para os insetos desalojados (Figura 2). 
Figura 2 - Captura de mosquitos adultos no intra domicílio (A) e peri-domicílio (B); acondicionamento dos mosquitos capturados (C) e preenchimento do boletim (D). Marília/SP, abril, 2009.
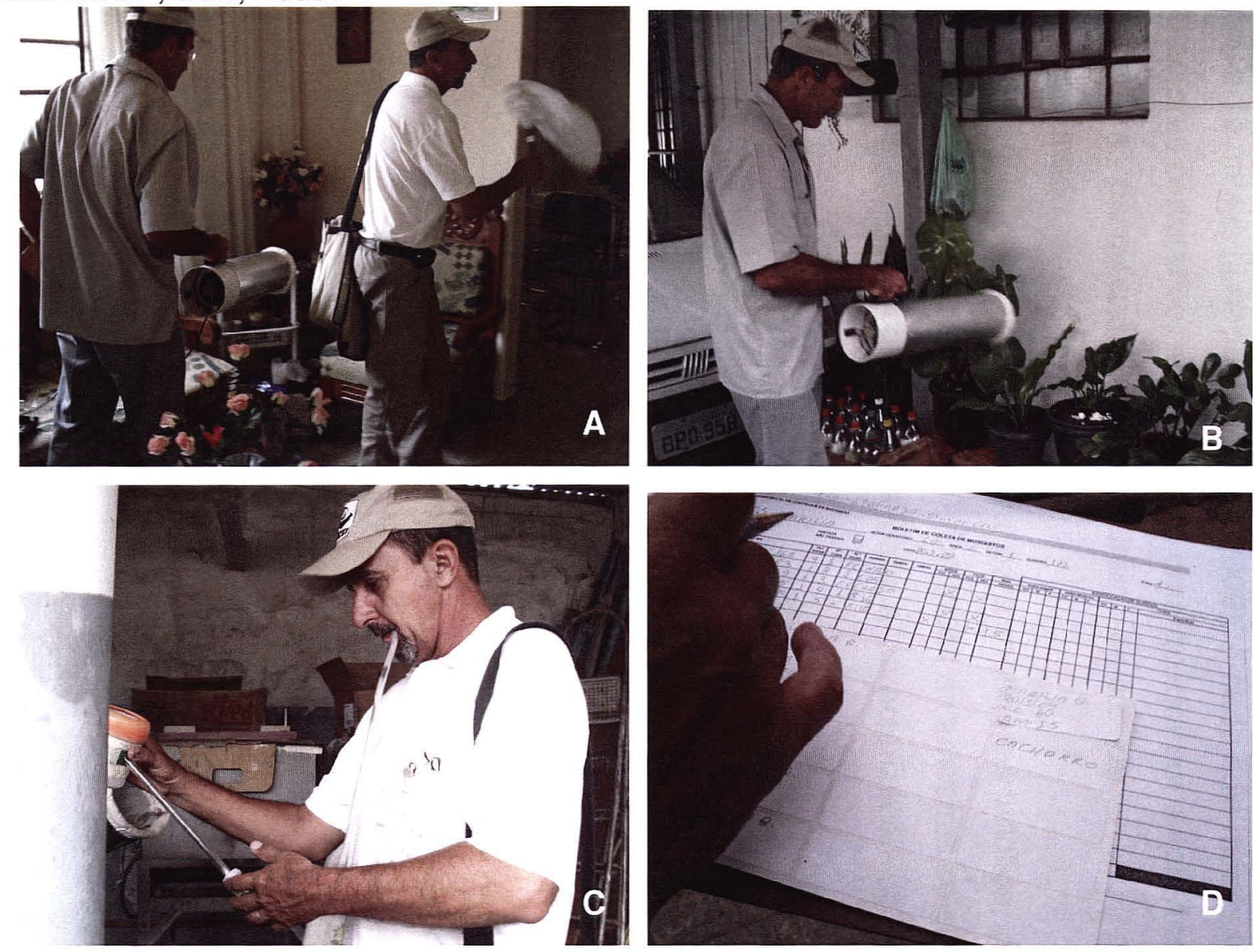


\subsubsection{Amostras}

As coletas de mosquitos adultos foram realizadas em 261 dos 263 setores censitários existentes no município de Marília. A periodicidade da coleta foi bimestral, sempre no final de um mês e início do mês seguinte, durante 2 anos e 10 meses (junho/2007 a abril/2009). A cada dois meses foram sorteados 60 setores censitários, e pesquisada uma quadra por setor. Assim a cada coleta foram pesquisadas 60 quadras, cerca de 1.500 casas (considerando as pendências).

Cada residência pesquisada, positiva para mosquitos adultos, gerou uma ou duas amostras (intra e peri-domicílio). De todas as amostras coletadas, foi feito novo sorteio de $10 \%$ das mesmas para a caracterização do hábito alimentar.

As amostras foram processadas, sendo cada fêmea colocada individualmente em um tubo plástico de $1,5 \mathrm{~mL}$ (tipo eppendor ${ }^{\mathrm{B}^{\mathrm{Q}}}$ ), onde foi adicionado $100 \mu \mathrm{l}$ de PBS. Em seguida, com o auxílio de um pistilo de polipropileno (Sigma-Aldrich Co, St Louis, MO, USA) acoplado a um triturador elétrico (Foredom, Bethel, $\mathrm{Ct}$ ), as fêmeas foram trituradas (Figura 3). Os pistilos usados em cada amostra foram lavados com $100 \mu \mathrm{l}$ de PBS, totalizando um volume final de $200 \mu \mathrm{l}$. Em seguida, as amostras devidamente etiquetadas e numeradas, foram então congeladas a $-20^{\circ} \mathrm{C}$ para posterior processamento. Todo o procedimento foi realizado em banho de gelo.

Figura 3 - A) fêmea em eppendorf ${ }^{(}$; B) trituração da fêmea em PBS; C) amostra pronta para ser congelada.
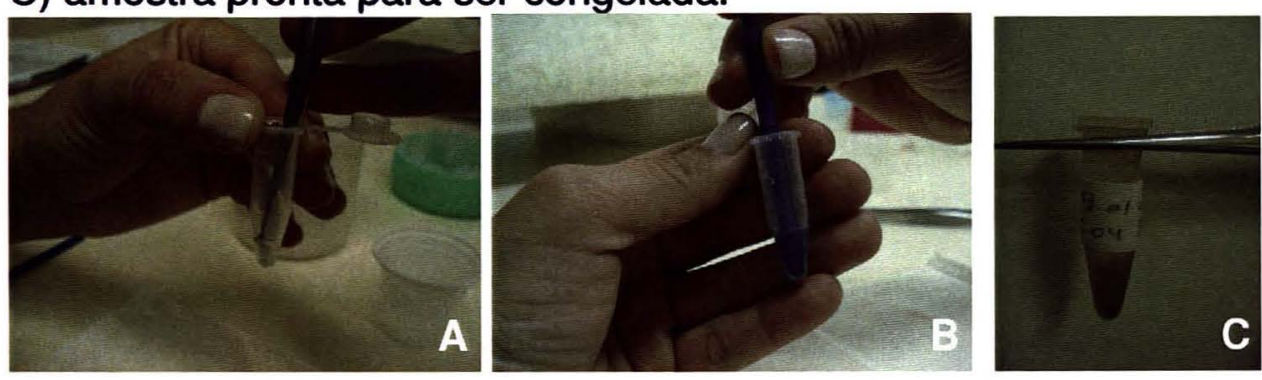

Cada eppendor ${ }^{(8)}$ contendo um exemplar de mosquito foi registrado com um número de ordem. Por esse número conseguiu-se localizar as 
informações para a organização dos dados como: local de captura, data da coleta, setor, localização (intra-domicílio ou peri-domicílio) e a espécie identificada.

\subsubsection{Avaliação do hábito alimentar através do teste ELISA (Enzyme} Linked Immunosorbent Assay)

$O$ teste ELISA indireto aqui utilizado detecta o sangue contido no estômago de fêmeas ingurgitadas, que contêm anticorpos específicos produzidos pelo sistema imunológico do animal picado pelo mosquito. No método, os anticorpos ligam-se aos antígenos adsorvidos à placa do teste e, após essa fase, anti-imunoglobulinas marcadas com enzima ligam-se aos anticorpos específicos. A reação da enzima degrada o substrato e realça a cor, que indica reação positiva.

Os testes com as fêmeas das amostras sorteadas foram realizados no Laboratório de Simulídeos da SUCEN de Caraguatatuba, sob orientação da Pesquisadora Dra. Maria Stela Branquinho.

O teste ELISA foi utilizado segundo metodologia de Chow et al. (1993) com modificações (VICENTIN, 2007), para a identificação do comportamento alimentar de Ae. aegypti e $C x$. quinquefasciatus, utilizando-se anti-soros de quatro hospedeiros: cão, galinha, homem e rato (Figura 4). Assim sendo, as titulações em bloco de anti-soros dos hospedeiros estudados e conjugados peroxidase correspondentes foram pré-estabelecidas.

Os quatro hospedeiros foram definidos por se tratarem de animais mais comumente encontrados em área urbana.

Para o controle negativo foram utilizados Ae. aegypti e $C x$. quinquefasciatus machos sabidamente não infectados, procedentes do Laboratório de Entomologia Aplicada da SUCEN de Marília. Para o controle positivo foram usados sangues dos respectivos animais, eluídos em papel filtro Watman no1.

Em cada placa teste, foi acrescentado um poço contendo todos os reagentes, porém substituindo o soro (amostra de mosquito triturado) por PBS 
("blank"). Em todas as placas utilizadas foram sados os controle positivos, negativos e o "blank".

Todos os testes foram realizados em duplicata e os limiares de reatividade ("cut off") foram calculados diariamente para cada placa, por meio da média do nível de absorbância de oito amostras negativas acrescidas de três desvios padrão ( $C O=X+3 S D$, onde $X=$ média aritmética do nível de absorbância e SD = desvio padrão).

Execução da Técnica

- As placas de microtitulação foram sensibilizadas com $50 \mu /$ poço de anti-soro de cão, rato, homem e galinha diluídos em PBS (um antisoro para cada placa) e permaneceram em câmara úmida a temperatura ambiente (TA) por uma hora;

- Após a retirada do conteúdo da sensibilização, as placas foram bloqueadas com $200 \mu$ /poço de solução de leite a $5 \%$ (leite+PBStween 20 0,05\% - PBS-T) e permaneceram em câmara úmida a TA por uma hora;

- Após a retirada do conteúdo do bloqueio, foram adicionados 50 $1 /$ poço das amostras dos mosquitos triturados, acrescidos os controles positivos (2 amostras), negativos (8 amostras) e "blank" (poço sem amostra de mosquito). As placas permaneceram em câmara úmida a TA por duas horas;

- Após três lavagens com solução de PBS-T, foram adicionados às placas $50 \mu /$ poço do conjugado peroxidase específico diluído em leite a 2,5\%. As placas permaneceram em câmara úmida a TA por uma hora;

- Novo ciclo de lavagens foi efetuado, adicionando-se a seguir $100 \mu 1 /$ poço de cromógeno ABTS (solução $A+B$ ). As placas foram colocadas em câmara escura por $\mathbf{3 0}$ minutos.

- A leitura de cada placa foi feita em leitor de ELISA (Reader $230 \mathrm{~S}$, Organon Teknika, Microwell System) a 405nm. 
Os anti-soros e conjugados enzimáticos foram utilizados nas seguintes diluições:

- Anticorpo lgG de humano

$-0,625 \mu l: 5000 \mu l$ para anti-soro de captura;

$-0,625 \mu \mathrm{l}: 5000 \mu \mathrm{l}$ para o conjugado peroxidase;

- Anticorpo IgG de galinha

$-0,625 \mu l: 5000 \mu l$ para anti-soro de captura;

$-0,625 \mu \mathrm{l}: 5000 \mu \mathrm{l}$ para o conjugado peroxidase;

- Anticorpo lgG de cão

$-0,835 \mu l: 5000 \mu l$ para anti-soro de captura;

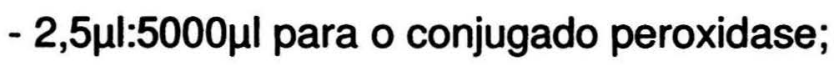

- Anticorpo lgG de rato

- 5,0 $\mu l: 5000 \mu l$ para anti-soro de captura;

$-1,8 \mu \mathrm{l}: 5000 \mu \mathrm{l}$ para o conjugado peroxidase. 
Figura 4 - Execução do teste ELISA para avaliação do hábito alimentar. Laboratório de Simulídeos/SUCEN, maio, 2009.
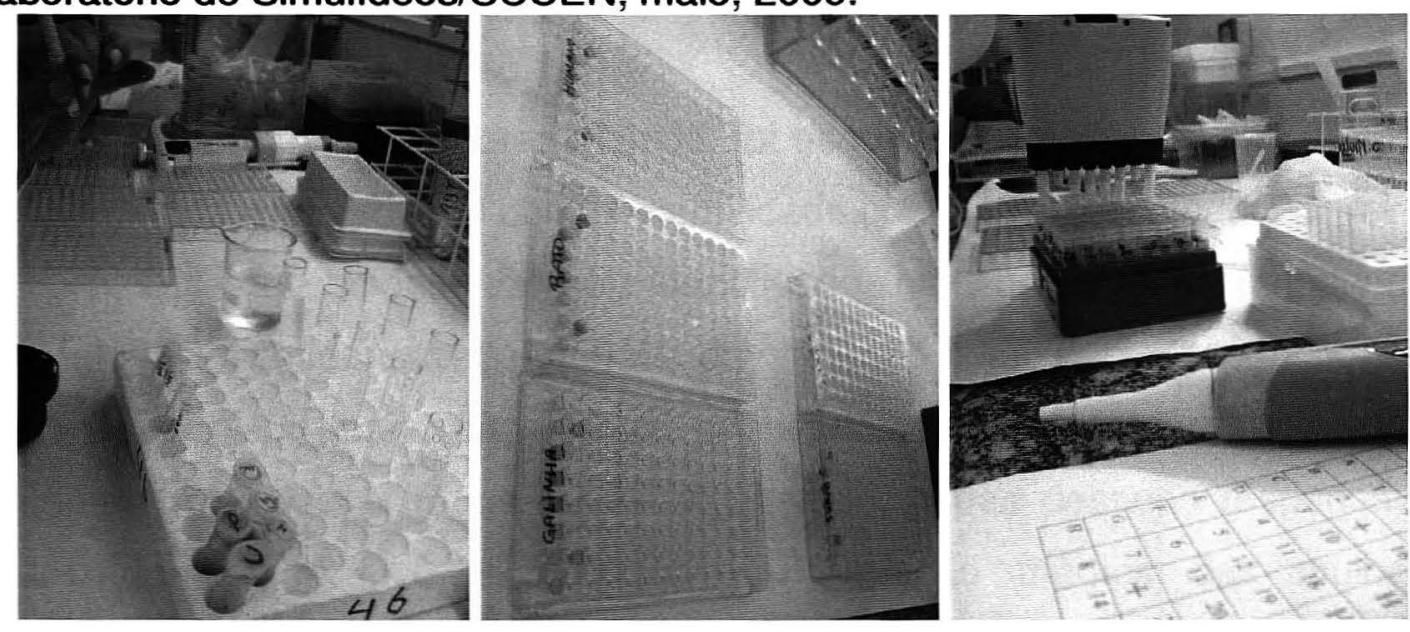

4.3.4. Relação da fonte alimentar observada com aspectos socioeconômicos e climáticos das áreas onde os insetos foram coletados.

As informações referentes aos 263 setores censitários da área urbana do município de Marília foram disponibilizadas pela Fundação Instituto Brasileiro de Geografia e Estatística (IBGE), com base no Censo Demográfico desenvolvido em 2000. Destes setores, quatro (os de números 20, 28, 74 e 86) referiam-se às áreas especiais (asilo, orfanato, hospital, presídio e outros) e três não continham habitantes em 2000 (os de números 108, 109 e 110). Assim, do total de setores, foram considerados 256.

Estes setores censitários foram caracterizados pelo seu nível socioeconômico, com base nas variáveis: renda e escolaridade (anos de instrução) médias das pessoas responsáveis pelos domicílios; renda e anos de instrução médios das mulheres responsáveis pelos domicílios; proporção de pessoas e de mulheres analfabetas e proporção de domicílios com cinco ou mais moradores. Essas variáveis foram analisadas por meio do programa STATA através da técnica estatística de análise de componentes principais 
(ALTMAN, 1999) que produz fatores não correlacionados entre si e que representam aspectos importantes caracterizados pelas correlações entre as variáveis.

Entre os vários fatores obtidos, foi escolhido o responsável pela maior proporção da variação total que foi identificado como o fator socioeconômico.

O fator socioeconômico, identificado na análise de componentes principais, foi responsável por $80 \%$ da variação total e corresponde a um escore calculado para cada setor censitário através da fórmula descrita anteriormente: $0,41 \times$ (anos de instrução médios das pessoas responsáveis pelos domicílios) $+0,39 \times$ (anos de instrução médios das mulheres responsáveis pelos domicílios) $+0,37 \times$ (renda média das pessoas responsáveis pelos domicílios) $+0,38 \times$ (renda média das mulheres responsáveis pelos domicílios) $+(-) 0,38 \times$ (proporções de pessoas analfabetas) $+(-)$ 0,39 $\times$ (proporção de mulheres analfabetas) $+(-) 0,32 \times$ (proporção de domicílios com cinco ou mais moradores).

Esse fator caracterizou os setores censitários segundo o seu nível socioeconômico, de tal forma que quanto maior seu valor, melhor o nível socioeconômico dos moradores de um determinado setor censitário do município. Os setores foram ordenados pelos respectivos valores do fator socioeconômico e agrupados segundo tercis. $\mathrm{O}$ agrupamento de setores com valores do fator socioeconômico abaixo do primeiro tercil foi classificado como de nível socioeconômico 1 (mais baixo), o agrupamento de setores com valores do fator entre o primeiro e o segundo tercis foi classificado como de nível socioeconômico 2 (intermediário) e o agrupamento de setores com valores do fator acima do segundo tercil foi classificado como de nível socioeconômico 3 (mais alto).

Os mosquitos capturados, cujos conteúdos estomacais foram analisados pela técnica ELISA e que revelaram presença de sangue de uma das espécies animais consideradas, foram alocados nos 256 setores e as informações referentes aos mesmos foram reunidas segundo os três agrupamentos de setores por nível socioeconômico. Desta forma, foi possível: testar, para cada espécie, a relação entre hábito alimentar e área da cidade 
segundo nível socioeconômico e verificar, para cada espécie, a ocupação do intra-domicílio e do peri-domicílio, segundo nível socioeconômico e variáveis climáticas.

Tabela 1 - Variáveis climáticas (temperatura em graus Celsius $\left({ }^{\circ} \mathrm{C}\right)$ e umidade relativa do ar) divididas em três categorias.

\begin{tabular}{|c|c|c|c|c|}
\hline \multirow{2}{*}{$\begin{array}{l}\text { Variáveis/ } \\
\text { Categorias }\end{array}$} & \multicolumn{3}{|c|}{ Temperatura } & \multirow[t]{2}{*}{ Umidade } \\
\hline & mínima & Máxima & média & \\
\hline 1 & $<15$ & $<30$ & $<22$ & $<35$ \\
\hline 2 & 15 a 17 & 30 a 33 & 22 a 24 & 35 a 50 \\
\hline 3 & $>17$ & $>33$ & $>24$ & $>50$ \\
\hline
\end{tabular}

As casas onde foram capturadas fêmeas positivas para ao menos uma das fontes sanguíneas foram investigadas quanto à presença de animais.

Além disso, cada casa onde foi feita a coleta dos mosquitos foi classificada de acordo com o método desenvolvido e validado por Tun-Lin et al. (1995), o Índice de Condição de Casa (ICC). Essa abordagem tem por objetivo examinar a relação de infestação de Ae. aegypti com a condição onde o mesmo foi encontrado através de três variáveis: grau de sombreamento, limpeza do quintal e estado da casa. Para cada variável atribuiu-se notas entre 1 a 3 da melhor para pior condição conforme mostra o quadro 1. 
Quadro 1 - Critério utilizado para avaliação das casas para determinar o ICC (Índice de Condição de Casa).

\begin{tabular}{|c|c|c|}
\hline NOTA & AVALIAÇÃO/CASA & CARACTERISTICA \\
\hline 1 & Bem mantida & $\begin{array}{c}\text { Casa pintada } \\
\text { recentemente ou nova. }\end{array}$ \\
\hline 2 & $\begin{array}{l}\text { Moderadamente } \\
\text { mantida }\end{array}$ & - \\
\hline 3 & Não bem mantida & $\begin{array}{l}\text { Pintura descascando, } \\
\text { itens visivelmente } \\
\text { quebrados, velha. }\end{array}$ \\
\hline NOTA & AVALIAÇÃO/QUINTAL & CARACTERISTICA \\
\hline 1 & Limpo & $\begin{array}{c}\text { Nenhum item jogado na } \\
\text { área externa, jardim } \\
\text { bem mantido, grama } \\
\text { aparada. }\end{array}$ \\
\hline 2 & Moderadamente limpo & - \\
\hline 3 & Não limpo & $\begin{array}{c}\text { Presença de lixo, grama } \\
\text { crescida. }\end{array}$ \\
\hline NOTA & \multicolumn{2}{|c|}{ AVALIAÇÃO/SOMBRA } \\
\hline 1 & \multicolumn{2}{|c|}{ Nenhuma sombra } \\
\hline 2 & \multicolumn{2}{|c|}{ Alguma sombra } \\
\hline 3 & \multicolumn{2}{|c|}{ Sombreado } \\
\hline
\end{tabular}

O ICC foi então estabelecido para cada casa pela soma das notas dadas para as três características (casa, quintal e sombra), variando de um mínimo de 3 (melhor condição) a ou máximo de 9 pontos (pior condição).

A fim de relacionar a distribuição das espécies com o ICC, foi utilizada a análise de correspondência, que é um método de análise fatorial para variáveis categóricas. Foi utilizada por Fisher em 1940 para a análise de tabelas de contingência e a seguir foi difundida na França por Benzecri (1969). O objetivo principal é a representação ótima da estrutura dos dados observados. É 
também, um meio de criar configurações representando as linhas da tabela por pontos no espaço, de tal forma que a distância Euclidiana entre os pontos na configuração seja igual à distância qui-quadrado calculada entre as linhas da tabela. Essa análise permite o estudo de tabelas de contingência (cruzamento de variáveis categóricas). Foi proposta inicialmente para o caso de análise conjunta de duas variáveis e mais tarde estendida para o estudo de um número qualquer de variáveis. Como exemplo de análises possíveis temos: para duas variáveis em estudo temos uma Análise Fatorial de Correspondências Simples ou Binárias e para o caso de mais variáveis temos a Análise Fatorial de Correspondências Múltiplas. É um método privilegiado na descrição de dados qualitativos, por suas propriedades estatísticas e pela riqueza de suas interpretações, ampliada pelo desenvolvimento de recursos computacionais. Dois grandes objetivos gerais da Análise Fatorial de Correspondências são: analisar toda informação contida em uma tabela de contingência e representar graficamente a estrutura da mesma. (ALVES et al., 2007)

Das variáveis estudadas, são categóricas: a espécie do mosquito (SPP), com as categorias Ae. aegytpi (AE) e Cx. quinquefasciatus (CX); 0 índice de condição de casa (ICC), com escore variando de 3 a 9; a estação do ano $(E)$ (verão=VE, inverno=IN, outono $=\mathrm{OU}$ e primavera=PR; o período $(P)$ seco (SEC) ou chuvoso (CHU); se o mosquito havia sugado sangue de humano (HOM), Galinha (GAL), cachorro (CAO) e Roedor (ROE), acrescido das categorias sim (S) e não (N); o hábito alimentar do mosquito (HAL): só sangue humano (SO_HU), só sangue de animal (SO_AN) e ambos (HU+AN), o local de encontro no domicílio (L): com as categorias intra (INT) e peri (PR). As variáveis referentes ao clima (temperaturas mínima, média e máxima e umidade média) foram categorizadas. A categorização das temperaturas mínima, média e máxima, assim como a umidade relativa do ar foram realizadas conforme mostra tabela abaixo. 


\subsection{AVALIAÇÃO DA CAPACIDADE REPRODUTIVA DOS CULICÍDEOS EM LABORATÓRIO}

4.4.1 Montagem do experimento para fornecimento de repasto sanguíneo

Foram montadas gaiolas com pupas fêmeas e machos de Ae. aegypti. O mesmo foi feito para $C x$. quinquefascitus. Ambas as populações são procedentes de colônias mantidas em laboratório, sendo os Ae. aegypti de Marília (SP) e os $C x$. quinquefasciatus de Recife (PE). Havia para todas as gaiolas, solução energética composta de água e mel (30\%). Diariamente as gaiolas eram observadas para verificação da presença de adultos, quando esses estavam presentes, retirava-se o copo com o restante das pupas. As pupas restantes eram levadas para formação de nova gaiola. Dessa forma foi possível saber a data exata da emergência dos mosquitos adultos.

0 repasto sanguíneo foi oferecido artificialmente por duas horas às fêmeas adultas com idade entre 3 e 7 dias. No momento do repasto sanguíneo os mosquitos estavam em jejum de alimentação energética de 24 horas. Durante a realização do experimento todos os grupos foram mantidos em insetário a $28^{\circ} \mathrm{C}$ e $80 \%$ de UR com fotoperíodo de $12 \mathrm{~h}$.

Tanto para os Ae. aegypti como para os Culex quinquefasciatus foram oferecidos sangue de quatro tipos de hospedeiros: ave, cão, roedor e humano.

$O$ sangue humano utilizado foi coletado pelo Banco de Sangue de Marília (FAMEMA) dentro das normas de biossegurança. A doação do sangue foi feita pela própria coordenadora do projeto e acondicionado em bolsa de sangue descartável com heparina. Por envolver sangue humano, o trabalho foi submetido ao Comitê de Ética da Faculdade de Saúde Pública da Universidade de São Paulo que dispensou a apreciação do Comitê.

$\mathrm{O}$ sangue de galinha foi obtido em frigorífico logo após o abate de animais. 
A coleta endovenosa do sangue de cão foi realizada por veterinário na Faculdade de Veterinária da Universidade de Marília.

O sangue de roedor foi coletado de coelhos abatidos na Faculdade de Veterinária da Universidade de Marília.

Todos os sangues colhidos (com exceção do sangue humano) foram acondicionados em tubos de $4 \mathrm{~mL}$ cada com Edta e mantidos sob refrigeração.

\subsubsection{Alimentação Artificial}

A alimentação dos culicídeos foi realizada através de alimentador artificial com membrana semipermeável de silicone e de tripa de boi para Ae. aegypti e Cx. quinquefasciatus, respectivamente. Para cada alimentação foram utilizados aproximadamente três $\mathrm{ml}$ de sangue mantido à $37^{\circ} \mathrm{C}$ em banho-maria (Figura 5).

Figura 5 - Modelo de alimentador artificial sobre gaiola.

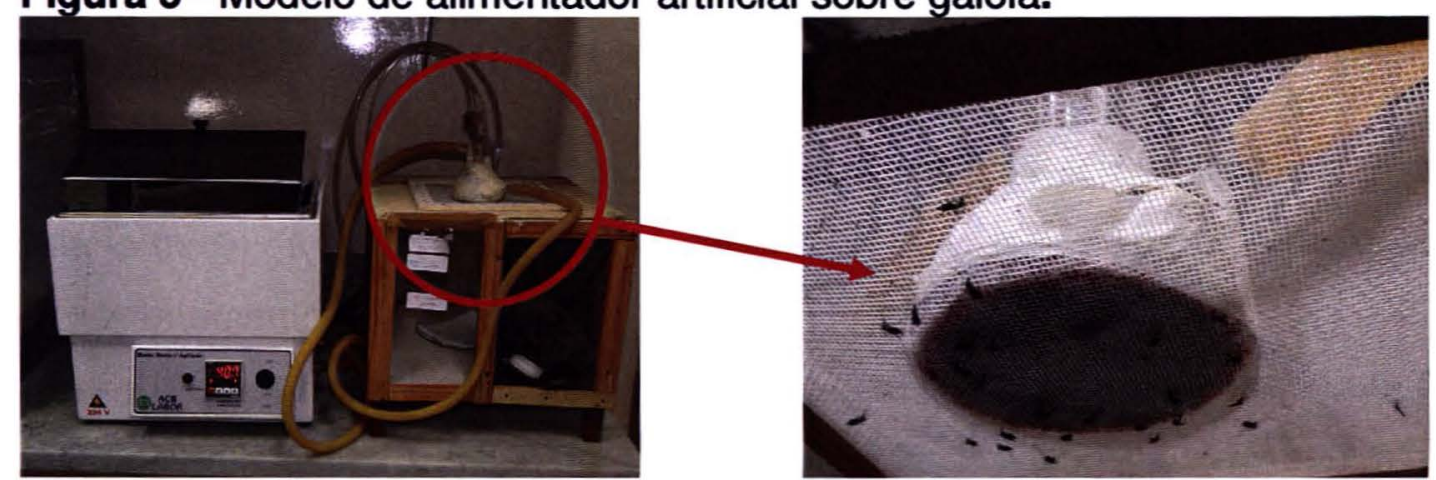

As fêmeas ingurgitadas foram transferidas para outra gaiola onde havia disponibilidade de alimentação energética e substrato para oviposição. Assim, durante o experimento foram formados oito grupos para observação. Cada gaiola recebeu um código que informava a qual dos grupos pertenciam (espécie e tipo de sangue utilizado para a alimentação) além de data do repasto sanguíneo, idade e o número de fêmeas alimentadas. $\mathrm{O}$ total de gaiolas formadas e o número de fêmeas alimentadas constam no Quadro 2. 
Quadro 2 - Gaiolas com fêmeas de culicídeos separadas por espécie e sangue de hospedeiro do qual se alimentaram.

\begin{tabular}{|c|c|c|c|c|}
\hline Espécie & $\begin{array}{l}\text { Sangue de } \\
\text { Hospedeiro }\end{array}$ & Sigla & № de Gaiolas & $\begin{array}{c}\mathrm{N}^{0} \mathrm{de} \\
\text { fêmeas } \\
\text { alimentadas }\end{array}$ \\
\hline \multirow{4}{*}{ Ae. aegypti } & Humano & $\mathrm{AH}$ & 09 & 339 \\
\hline & Cão & $\mathrm{AC}$ & 06 & 262 \\
\hline & Galinha & AG & 07 & 163 \\
\hline & Roedor & AR & 01 & 67 \\
\hline \multirow{4}{*}{$\begin{array}{c}C x . \\
\text { quinquefasciatus }\end{array}$} & Humano & $\mathrm{CH}$ & 08 & 110 \\
\hline & Cão & $\mathrm{CC}$ & 03 & 42 \\
\hline & Galinha & CG & 04 & 63 \\
\hline & Roedor & CR & 06 & 145 \\
\hline
\end{tabular}

$\mathrm{AH}=$ fêmeas de Ae. aegypti alimentadas com sangue humano;AC= fêmeas de Ae. aegypti alimentadas com sangue de cão; $\mathbf{A G}=$ fêmeas de $\mathbf{A e}$. aegypti alimentadas com sangue de galinha; $\mathrm{AR}=$ fêmeas de $\mathbf{A e}$. aegypti alimentadas com sangue de roedor; $\mathrm{CH}=$ fêmeas de $C x$.quinquefasciatus alimentadas com sangue humano;CC= têmeas de Cx.quinquefasciatus alimentadas com sangue de cão; $\mathrm{CG}=$ fêmeas de Cx.quinquefasciatus alimentadas com sangue de galinha; $\mathrm{CR}=$ fêmeas de Cx.quinquefasciatus alimentadas com sangue de roedor.

O substrato utilizado para $A e$. aegypti era um copo de vidro com fitas de papel filtro parcialmente imersas em água. As fitas com ovos eram trocadas diariamente e colocadas para secar por 24 horas para que os ovos embrionamento dos ovos.

O substrato para oviposição dos Culex era um copo de vidro com água. Diariamente esses copos eram observados para verificação da presença de jangadas com ovos.

As gaiolas eram descartadas após constatação de ausência de oviposição por três e sete dias seguidos para as gaiolas com Ae. aegypti e Cx.quinquefasciatus, respectivamente. 
4.4.3. Criação dos ovos obtidos em cada tipo de repasto sanguíneo

As fitas contendo ovos de Ae. aegypti eram colocadas para eclosão em água com feno a $10 \%$ na proporção de $2 \mathrm{~mL}$ ovo e $1 \mathrm{mg}$ de ração. Os recipientes eram observados diariamente. Se fosse necessário era realizada a troca de água e reposição de comida (Figura 6).

Figura 6 - Bacias de criação para a observação do tempo de desenvolvimento de culicídeos. Laboratório de Entomologia Aplicada/SUCEN/Marilia, SP. Ago/2010.

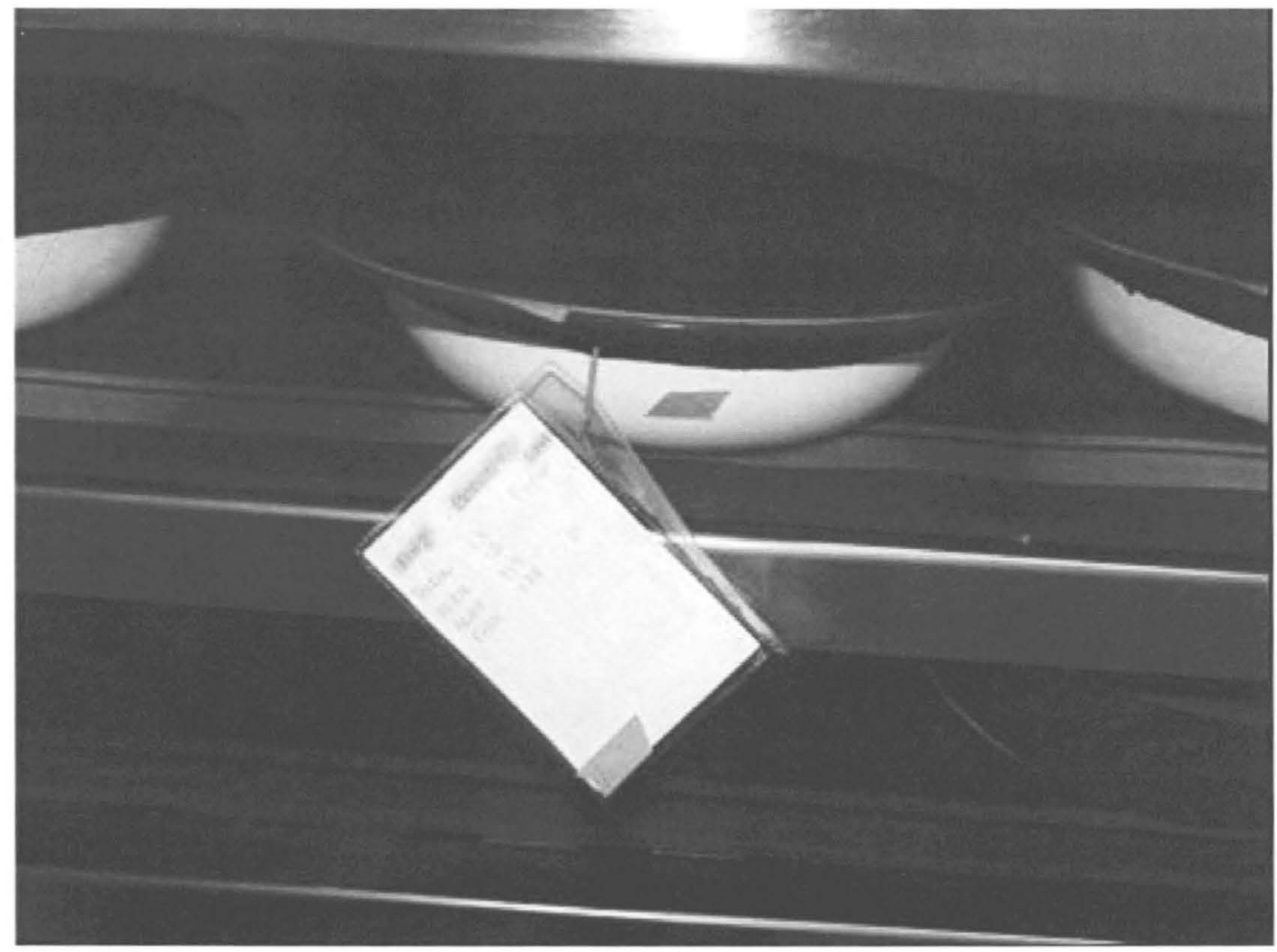




\subsubsection{Parâmetros Observados}

A avaliação da capacidade reprodutiva baseou-se na observação dos parâmetros: tempo de desenvolvimento e fertilidade.

a) Fertilidade: percentual de emergência de pupas. Para cada grupo de ovos embrionados foram colocados 100 ovos em recipiente com água para eclosão das larvas que tiveram seu desenvolvimento acompanhado diariamente até a fase de pupa.

b) Tempo de desenvolvimento e sobrevivência da fase imatura: o tempo para pupação e ou mortalidade das larvas foi contado em dias até o final do experimento.

Os dados foram digitados em banco de dados criado no Acces e Excel. 


\subsection{ANÁLISE ESTATÍSTICA}

Análise não paramétrica de Kruskall-Wallis $(H)$ foi utilizada no nível de $5 \%(a=0,05)$ para verificar se existem diferenças entre as médias de ovos postos por fêmeas sobreviventes de Ae. aegypti alimentadas com sangue humano, de cão, de ave e de roedor. $O$ mesmo foi feito para fêmeas sobreviventes de $C x$. quinquefasciatus.

O modelo de regressão linear simples foi utilizado para verificar a influência ou efeito da variável independente $x$ (dias de observação) sobre a variável dependente (y) média de ovos postos por fêmeas sobreviventes de $A e$. aegypti e $C x$. quinquefasciatus quando alimentadas com sangue de diferentes hospedeiros.

A análise de regressão linear simples também foi utilizada na comparação do percentual de pupação de imaturos provenientes de fêmeas de Ae. aegypti e $C x$. quinquefasciatus alimentadas com sangue de diferentes hospedeiros.

Os pressupostos básicos da análise de regressão não obtidos pelos testes de Kolmogorov-Smirnov e Levere foram corrigidos pela transformação da variável dependente $(y)$ em $\log (y+1)$. 


\section{RESULTADOS}

\subsection{HÁBITO ALIMENTAR DE FÊMEAS COLETADAS EM CAMPO}

Foram identificadas as seguintes espécies: Ae. aegypti, Ae. albopictus, Ae. scapularis, Cx. quinquefasciatus .

Dos 917 mosquitos selecionados para a caracterização do hábito alimentar, 913 fêmeas foram analisadas pelo teste ELISA quanto à realização de repasto sanguíneo, 523 delas não se alimentaram e 390 fizeram ao menos um repasto. A Tabela 2 mostra o número de fêmeas examinadas por local de coleta, fonte alimentar, estação do ano, período e temperatura.

Tabela 2 Número de fêmeas de Ae. aegypti e Cx. quinquefasciatus examinadas segundo local de coleta, fonte alimentar, estação do ano, período e temperatura.

\begin{tabular}{|c|c|c|c|c|c|c|c|c|c|c|c|c|}
\hline \multicolumn{13}{|c|}{ ICC } \\
\hline & x & & 0 & 3 & 4 & 5 & 6 & 7 & & 8 & 9 & Total \\
\hline \multicolumn{3}{|c|}{$N^{\circ}$ fêmeas } & 3 & 0 & 12 & 14 & 36 & 8 & & 4 & 4 & 81 \\
\hline \multirow{2}{*}{ Local } & INT & & 3 & 0 & 12 & 12 & 32 & 8 & & 4 & 4 & 75 \\
\hline & PER & & 0 & 0 & 0 & 2 & 4 & 0 & & 0 & 0 & 6 \\
\hline & Hom & & 3 & 0 & 10 & 9 & 25 & 5 & & 3 & 4 & 59 \\
\hline & Cão & & 0 & 0 & 1 & 3 & 3 & 2 & & 2 & 0 & 11 \\
\hline & Gal & & 0 & 0 & 1 & 2 & 4 & 1 & & 0 & 0 & 8 \\
\hline & Rat & & 1 & 0 & $\underline{0}$ & 1 & 4 & 0 & & 0 & 0 & 6 \\
\hline \multirow{3}{*}{$\frac{8}{2} \frac{2}{2}$} & SO_H & & 0 & 0 & 10 & 9 & 25 & 5 & & 2 & 4 & 55 \\
\hline & SO A & & 2 & 0 & 2 & 5 & 10 & 3 & & 1 & 0 & 23 \\
\hline & muss. & & 1 & 0 & 0 & 0 & 1 & 0 & & 1 & 0 & 3 \\
\hline \multirow{4}{*}{ 递 } & Prim & & 0 & 0 & 5 & 4 & 7 & 0 & & 2 & 2 & 20 \\
\hline & Ver & & 1 & 0 & 2 & 4 & 21 & 6 & & 1 & 2 & 37 \\
\hline & Out & & 1 & 0 & 1 & 3 & 4 & 0 & & 1 & 0 & 10 \\
\hline & Inv & & 1 & 0 & 4 & 3 & 4 & 2 & & 0 & 0 & 14 \\
\hline \multirow{2}{*}{ Período } & , $\mathrm{CHU}$ & & $\overline{2}$ & 0 & 8 & 10 & 29 & 6 & & 3 & 3 & 61 \\
\hline & SEC & & 1 & 0 & 4 & 4 & 7 & 2 & & 1 & 1 & 20 \\
\hline \multirow{9}{*}{ 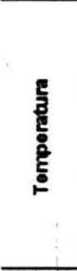 } & $\min$ & 1 & 0 & 0 & 1 & 3 & 4 & 2 & & 1 & 0 & 11 \\
\hline & $\min$ & 2 & 0 & 0 & 2 & 3 & 2 & 1 & & 0 & 1 & 9 \\
\hline & $\min$ & 3 & 3 & 0 & 9 & 8 & 30 & 5 & & 3 & 3 & 61 \\
\hline & med & 1 & 1 & 0 & 1 & 3 & 5 & 2 & & 1 & 1 & 14 \\
\hline & med & 2 & 1 & 0 & 2 & 4 & 3 & 0 & & 0 & 0 & 10 \\
\hline & med & 3 & 1 & 0 & 9 & 7 & 28 & 6 & & 3 & 3 & 57 \\
\hline & $\max$ & 1 & 2 & 0 & 3 & 5 & 13 & 3 & & 1 & 3 & 30 \\
\hline & $\max$ & 2 & 1 & 0 & 4 & 8 & 14 & 3 & & 2 & 0 & 32 \\
\hline & $\max$ & 3 & 0 & 0 & 5 & 1 & 9 & 2 & & 1 & 1 & 19 \\
\hline \multirow{3}{*}{ UR } & & 1 & 0 & 0 & 3 & 0 & 1 & 0 & & 0 & 0 & 4 \\
\hline & & 2 & 0 & 0 & 1 & 6 & 8 & 5 & & 1 & 1 & 22 \\
\hline & 0 & 3 & 3 & 0 & 8 & 8 & 27 & 3 & & 3 & 3 & 55 \\
\hline
\end{tabular}

\begin{tabular}{|c|c|c|c|c|c|c|c|c|c|c|c|}
\hline \multicolumn{12}{|c|}{ ICC } \\
\hline \multicolumn{3}{|c|}{ 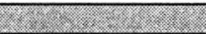 } & 0 & 3 & 4 & 5 & 6 & 7 & 8 & 9 & Total \\
\hline \multicolumn{3}{|c|}{$N^{\circ}$ fêmeas } & 7 & 3 & 16 & 64 & 113 & 34 & 34 & 6 & 277 \\
\hline \multirow{2}{*}{ Local } & WT & & 7 & 3 & 16 & 56 & 103 & 31 & 28 & 6 & 250 \\
\hline & PER & & 0 & 0 & 0 & 8 & 10 & 3. & 6 & 0 & 27 \\
\hline \multirow{4}{*}{ 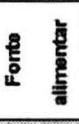 } & Hom & & 0 & 3 & 8 & 6 & 51 & 14 & 23 & 4 & 109 \\
\hline & Cão & & 2 & 0 & 1 & 14 & 23 & 4 & 4 & 0 & 48 \\
\hline & Gal & & 5 & 0 & 2 & 0 & 15 & 6 & 2 & 2 & 32 \\
\hline & Rat & & 0 & 0 & 6 & 34 & 45 & 12 & 6 & 0 & 103 \\
\hline \multirow{3}{*}{$\frac{8}{2}=\frac{2}{2}$} & so $\mathrm{HuM}$ & & 0 & 3 & 8 & 12 & 34 & 14 & 22 & 4 & 97 \\
\hline & SO_An & & 7 & 0 & 8 & 51 & 62 & 20 & 11 & 2 & 161 \\
\hline & HuM+AN & & 0 & 0 & 0 & 1 & 17 & 0 & 1 & 0 & 19 \\
\hline \multirow{4}{*}{ 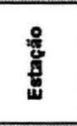 } & Prim & & 2 & 0 & 7 & 11 & 23 & 5 & 18 & 2 & 68 \\
\hline & Ver & & 2 & 0 & 2 & 2 & 6 & 6 & 1 & 1 & 20 \\
\hline & Out & & 0 & 0 & 0 & 0 & 3 & 6 & 2 & 0 & 11 \\
\hline & Inv & & 3 & 3 & 7 & 51 & 81 & 17 & 13 & 3 & 178 \\
\hline \multirow{2}{*}{ Periodo } & $\mathrm{CHO}$ & & 4 & 0 & 9 & 13 & 28 & 11 & 20 & 2 & 87 \\
\hline & SEC & & 3 & 3 & 7 & 51 & 85 & 23 & 14 & 4 & 190 \\
\hline \multirow{9}{*}{ 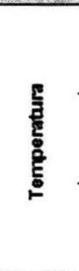 } & $\min$ & 1 & 0 & 0 & 1 & 10 & 58 & 8 & 11 & 1 & $\overline{89}$ \\
\hline & $\min$ & 2 & 3 & 0 & 6 & 42 & 18 & 12 & 3 & 3 & 87 \\
\hline & $\min$ & 3 & 4 & 3 & 9 & 36 & 37 & 14 & 20 & 2 & 125 \\
\hline & med & 1 & 0 & 0 & 1 & 5 & 49 & 9 & 6 & 4 & 74 \\
\hline & med & 2 & 3 & 3 & 6 & 24 & 31 & 6 & 8 & 0 & 81 \\
\hline & med & 3 & 4 & 0 & 9 & 35 & 33 & 19 & 20 & 2 & 122 \\
\hline & $\max$ & 1 & 0 & 3 & 1 & 5 & 44 & 10 & 4 & 6 & 73 \\
\hline & $\max$ & 2 & 7 & 0 & 9 & 33 & 56 & 19 & 28 & 0 & 152 \\
\hline & $\max$ & 3 & 0 & 0 & 6 & 26 & 13 & 5 & 2 & 0 & $\begin{array}{r}72 \\
\end{array}$ \\
\hline \multirow{3}{*}{ UR } & & 1 & 0 & 0 & 5 & 37 & 33 & 8 & 8 & 0 & 791 \\
\hline & & 2 & 7 & 3 & 3 & 24 & 47 & 6 & 6 & 1 & 97 \\
\hline & & 3 & 0 & 0 & 8 & 3 & 33 & 20 & 20 & 5 & $\begin{array}{r}79 \\
\end{array}$ \\
\hline
\end{tabular}

ICC= índice de condição de casa; INT = intra-domicílio; PER= Peri-domicílio, SO_HUM = fonte alimentar somente em humano; SO_AN = fonte alimentar somente em animal; HUM+NA = fonte alimentar em humano e em animal; Prim = primavera; Ver = verão; Out = outono; Inv = inverno; $\mathrm{CH}=$ período chuvoso; SEC = período seco; UR = umidade relativa. 
A Tabela 3 mostra 0 número de fêmeas que realizaram repasto sanguíneo em um dos quatro hospedeiros testados por espécie.

Tabela 3 - Número de fêmeas coletadas que realizaram repasto sanguíneo em um dos hospedeiros testados (homem, cão, ave e/ou roedor). Marília, SP, junho de 2007 a agosto de 2008.

Fonte alimentar

\begin{tabular}{lccccc}
\multirow{2}{*}{ Espécie } & Total & \multicolumn{2}{c}{ Identificada } & \multicolumn{2}{c}{ Não Identificada } \\
\cline { 3 - 6 } & & $\mathrm{N}$ & $\%$ & $\mathrm{~N}$ & $\%$ \\
\hline Ae. aegypti & 254 & 86 & 33,9 & 168 & 66,1 \\
Cx. quinquefasciatus & 645 & 295 & 45,7 & 350 & 54,3 \\
Ae. scapularis & 12 & 7 & 58,3 & 5 & 41,7 \\
Ae. albopictus & 2 & 2 & 100 & 0 & 0,0 \\
\hline TOTAL & 913 & 390 & 42,7 & 523 & 57,3 \\
\hline
\end{tabular}

Para a análise do hábito alimentar foram consideradas apenas as espécies mais abundantes: o Ae. aegypti e o Cx. quinquefasciatus.

A preferência alimentar específica, ou seja, o repasto realizado em apenas um tipo de hospedeiro foi observado na maior parte das fêmeas (Figura 7). 
Figura 7 - Percentual de fêmeas de Ae. aegypti e Cx. quinquefasciatus alimentadas que realizaram um ou mais repastos.

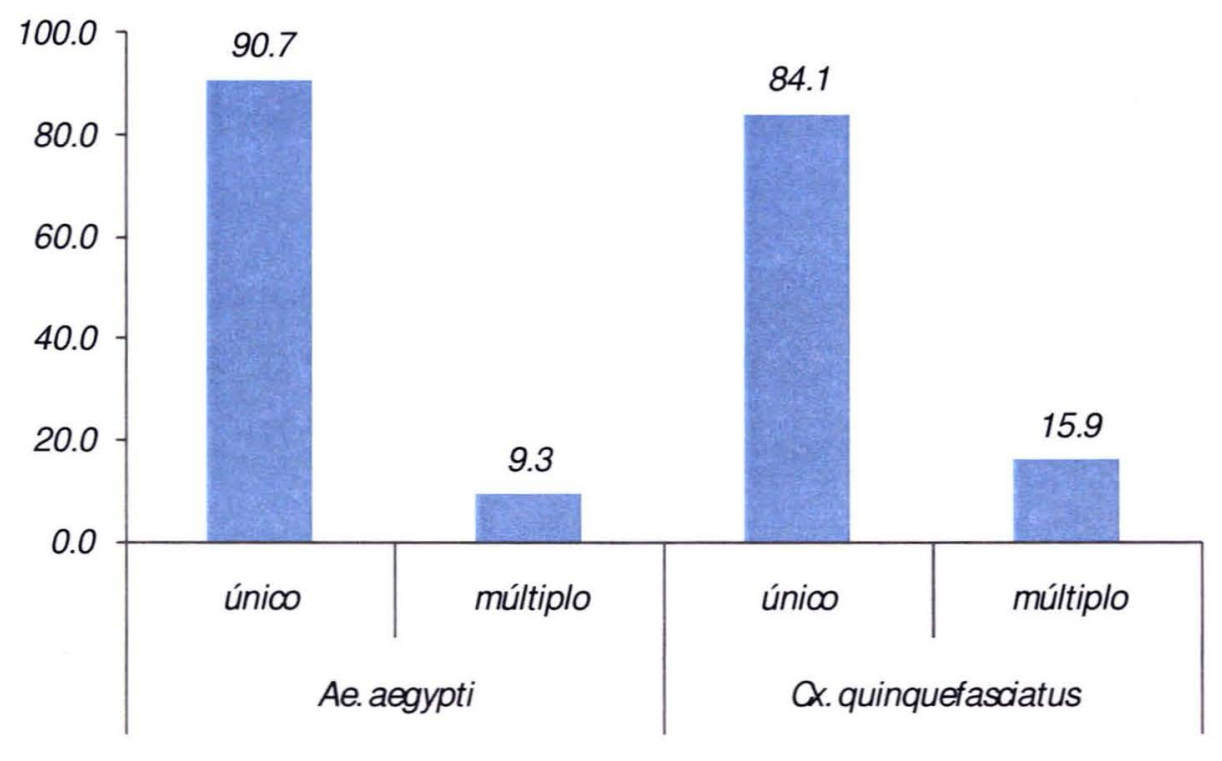

Entre as fêmeas que se alimentaram apenas em um hospedeiro destaca-se a preferência alimentar dos Ae. aegypti por humanos. Os $C x$. quinquefasciatus apresentaram comportamento mais eclético quanto à escolha do hospedeiro conforme ilustra Figura 8.

Figura 8 - Percentual de fêmeas de Ae. aegypti e $C x$. quinquefasciatus que realizaram repasto único em diferentes hospedeiros.

Ae. aegypti

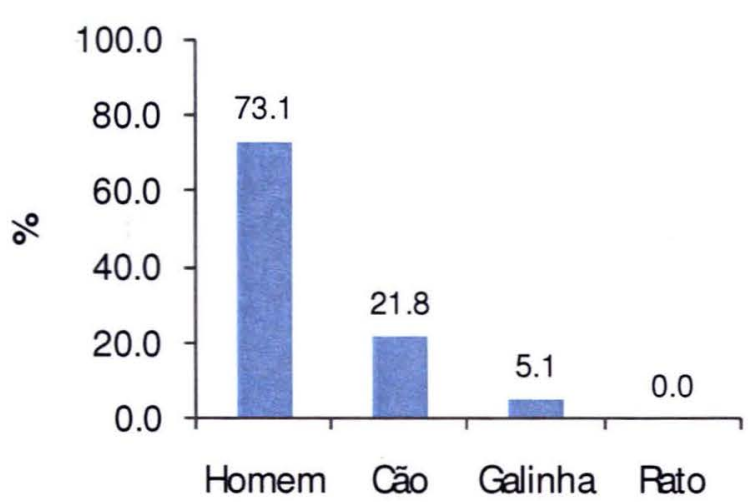

Q. quinquefasciatus

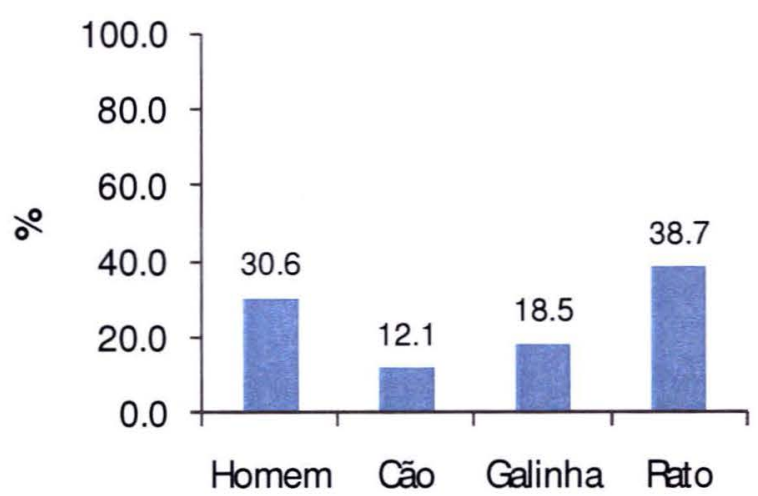


Repastos múltiplos foram observados em fêmeas de Ae. aegypti (8/86) e $C x$. quinquefasciatus (48/295) (Figura 9). Uma fêmea de $C x$. quinquefasciatus realizou o repasto triplo: galinha, cachorro e rato. 
Figura 9 - Percentual de repastos múltiplos realizados por fêmeas de Aedes aegypti e Culex quinquefasciatus em um dos quatro hospedeiros testados: humano $(H)$, cão $(C)$, galinha $(G)$ e roedor $(R)$.

Ae. aegypti

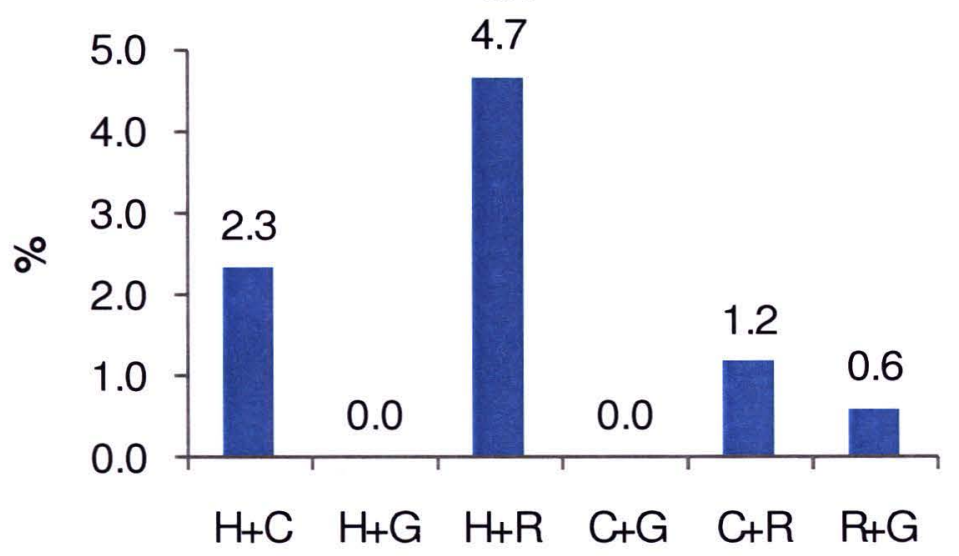

Cx. quinquefasciatus

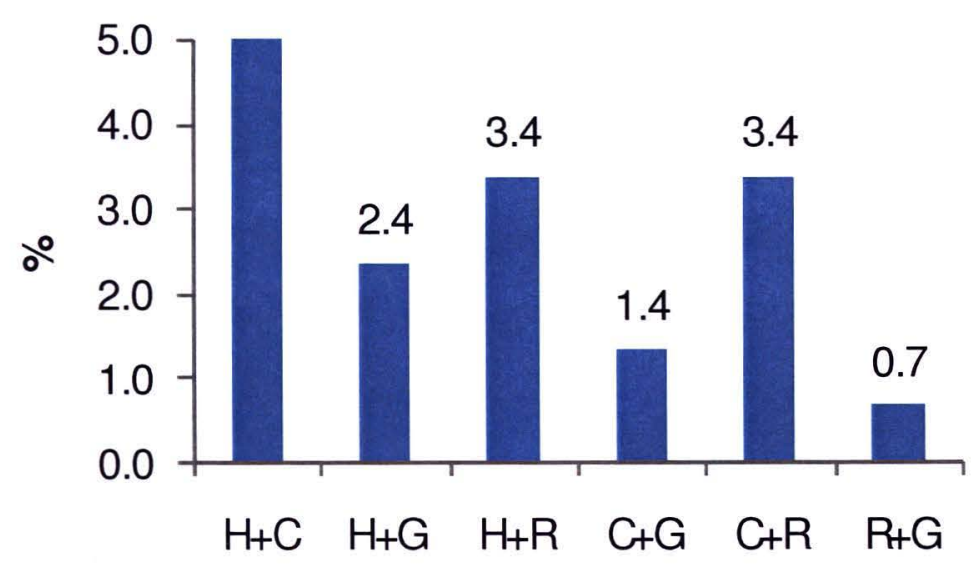

5.1.1. Fonte alimentar e aspectos socioeconômicos das áreas onde os insetos foram coletados.

O fator socioeconômico, identificado na análise de componentes principais, descritos anteriormente, gerou o mapa da área urbana de Marília com os setores censitários categorizados segundo nível socioeconômico (Figura 10). 
Figura 10 - Mapa da área urbana do município de Marília, SP apresentando os setores censitários segundo nível socioeconômico, 2000.

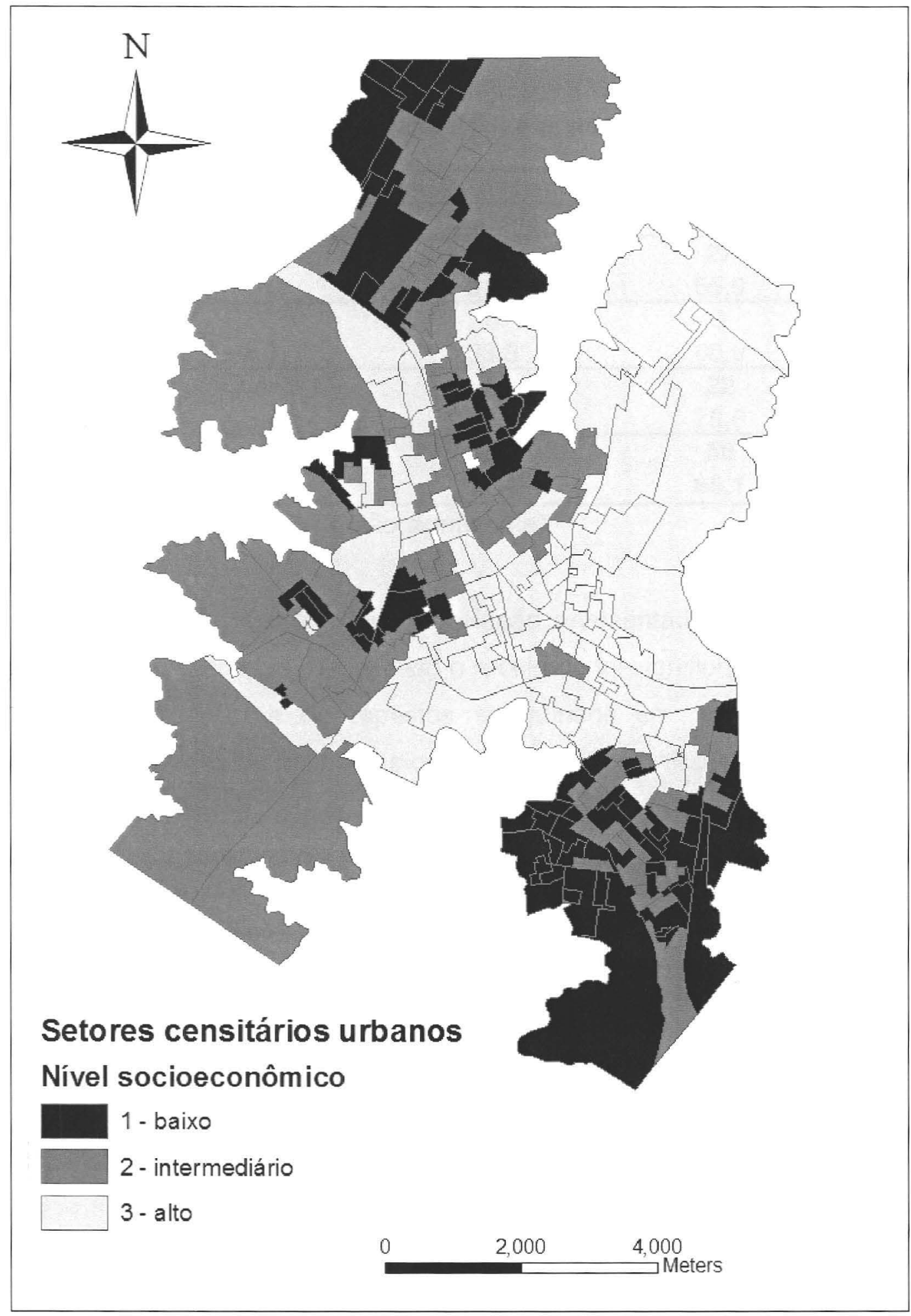


A Tabela 4 mostra a relação entre nível socioeconômico e fonte alimentar sanguínea para Ae. aegypti. Nota-se que o comportamento dessas fêmeas foi semelhante nos três agrupamentos de setores.

Tabela 4 - Relação entre nível socioeconômico e repasto sanguíneo realizado por fêmeas de Ae. aegypti em humano (HU) e animal (AN).

\begin{tabular}{|c|c|c|c|c|c|}
\hline \multirow{2}{*}{ Nível } & \multirow{2}{*}{ Dados } & \multicolumn{3}{|c|}{ Hábito Alimentar } & \multirow{2}{*}{ Total geral } \\
\hline & & $\mathrm{HU}+\mathrm{AN}$ & SO AN & SO HU & \\
\hline & $\mathbf{N}$ & 1 & 13 & 27 & 41 \\
\hline \multirow[t]{2}{*}{1} & $\%$ & 2,44 & 31,7 & 65,9 & 100 \\
\hline & $\mathbf{N}$ & 1 & 5 & 9 & 15 \\
\hline \multirow[t]{2}{*}{$\underline{2}$} & $\%$ & 6,7 & 33,3 & 60.0 & 100 \\
\hline & $\bar{N}$ & 1 & 5 & 22 & 28 \\
\hline 3 & $\%$ & 3,6 & 17,9 & 78,6 & 100 \\
\hline $\begin{array}{l}\text { Total } \\
\%\end{array}$ & & $\begin{array}{c}3 \\
3.6\end{array}$ & $\begin{array}{c}23 \\
274\end{array}$ & $\begin{array}{c}58 \\
69.1\end{array}$ & $\begin{array}{c}84 \\
100\end{array}$ \\
\hline
\end{tabular}

(teste $G=0,1411, p=0,9373$, não signficante)

A Tabela 5 mostra a mesma relação apresentada na Tabela 4, mas para $C x$. quinquefasciatus. Neste caso o resultado foi significante e nota-se que houve maior frequência de repastos sanguíneos em "só animais" e "só humanos", nas áreas de melhor e pior nível socioeconômico, respectivamente.

Tabela 5 - Relação entre nível socioeconômico e repasto sanguíneo realizado por fêmeas de $C x$. quinquefasciatus em humano (HU) e animal (AN).

\begin{tabular}{|c|c|c|c|c|c|}
\hline \multirow{2}{*}{ Nível } & \multirow{2}{*}{ Dados } & \multicolumn{3}{|c|}{ Hábito Alimentar } & \multirow{2}{*}{ Total geral } \\
\hline & & $\mathrm{HU}+\mathrm{AN}$ & SO_AN & SO_HU & \\
\hline \multirow{2}{*}{1} & $\mathbf{N}$ & 8 & 57 & 67 & 132 \\
\hline & $\%$ & 6,1 & 43,2 & 50,8 & 100 \\
\hline \multirow{2}{*}{2} & $\bar{N}$ & 8 & 49 & 21 & 78 \\
\hline & $\%$ & 10,3 & 62,8 & 26,9 & 100 \\
\hline \multirow{2}{*}{3} & $\mathbf{N}$ & 3 & 55 & 8 & 66 \\
\hline & $\%$ & 4,6 & 83,3 & 12,1 & 1 \\
\hline \multirow{2}{*}{\multicolumn{2}{|c|}{$\begin{array}{l}\text { Total } \\
\%\end{array}$}} & 19 & 161 & 96 & 276 \\
\hline & & 6,9 & 58,3 & 34,8 & 100 \\
\hline
\end{tabular}

(Teste $\mathrm{G}=37,08, \mathrm{p}<0,0001$, significante) 
As Tabelas 6 e 7 mostram, respectivamente, a relação entre o local de encontro de $A e$. aegypti e $C x$. quinquefasciatus na casa e o nível socioeconômico. As duas relações apresentaram resultados não significantes.

Tabela 6 - Relação entre local de captura de Ae. aegypti - Intra (INT) e Peridomicílio (PER) e área socioeconômica.

\begin{tabular}{|c|c|c|c|c|}
\hline \multirow{2}{*}{ Nivel } & \multirow{2}{*}{ Dados } & \multicolumn{2}{|c|}{ Local } & \multirow{2}{*}{ Total gera } \\
\hline & & INT & PER & \\
\hline \multirow{2}{*}{1} & $\mathbf{N}$ & 37 & 4 & 41 \\
\hline & $\%$ & 90,2 & 9,8 & 100 \\
\hline \multirow{2}{*}{2} & $\mathbf{N}$ & 13 & 2 & 15 \\
\hline & $\%$ & 86,7 & 13,3 & 100 \\
\hline \multirow{2}{*}{3} & $\mathbf{N}$ & 25 & 3 & 28 \\
\hline & $\%$ & 89,3 & 10,7 & 100 \\
\hline $\begin{array}{l}\text { Total } \\
\%\end{array}$ & & $\begin{array}{c}75 \\
89,3\end{array}$ & $\begin{array}{c}9 \\
10.7\end{array}$ & $\begin{array}{c}84 \\
100\end{array}$ \\
\hline
\end{tabular}

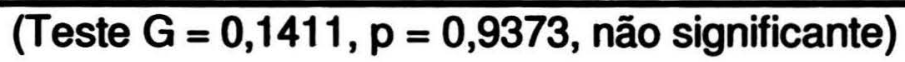

Tabela 7 - Relação entre local de captura de Cx. quinquefasciatus - Intra (INT) e Peri-domicílio (PER) e área socioeconômica.

\begin{tabular}{|c|c|c|c|c|}
\hline \multirow{2}{*}{ Nível } & \multirow{2}{*}{ Dados } & \multicolumn{2}{|c|}{ Local } & \multirow{2}{*}{ Total gera } \\
\hline & & INT & PER & \\
\hline \multirow{2}{*}{1} & $\mathbf{N}$ & 119 & 13 & 132 \\
\hline & $\%$ & 90,1 & 9,9 & 100 \\
\hline \multirow{2}{*}{2} & $\mathbf{N}$ & 71 & 7 & 78 \\
\hline & $\%$ & 91,0 & 9,0 & 100 \\
\hline \multirow{2}{*}{3} & $\mathbf{N}$ & 57 & 9 & 66 \\
\hline & $\%$ & 86,4 & 13,6 & 100 \\
\hline \multicolumn{2}{|l|}{ Total } & 247 & 29 & 276 \\
\hline \multicolumn{2}{|l|}{$\%$} & 89,5 & 10,5 & 100 \\
\hline
\end{tabular}

(Teste qui-quadrado $=0,843, p=0,6240$, não significante)

Utilizou-se a técnica estatística de análise de correspondência foi utilizada inicialmente para avaliar a relação entre os vetores capturados e seus hábitos alimentares (Figura 11). Dos três fatores produzidos foram utilizados 
os dois primeiros para explicar os dados, os quais foram responsáveis, respectivamente, por $51,5 \%$ e $3,0 \%$ da variação total. $O$ fator 1 (horizontal) mostrou associação do Ae. aegypti com sangue humano (HOM=S) e do $C x$. quinquefasciatus com sangue de rato (RAT=S), galinha ( $G A L=S$ ) e cachorro (CAO=S). Em função destes resultados, o hábito alimentar dos mosquitos foi considerado, na análise conjunta, em três categorias: só sangue humano, só sangue de animal e ambos.

Figura 11 - Análise de correspondência das variáveis: tipo de vetor (Ae. aegypti e Cx. quinquefasciatus) e hábito alimentar.

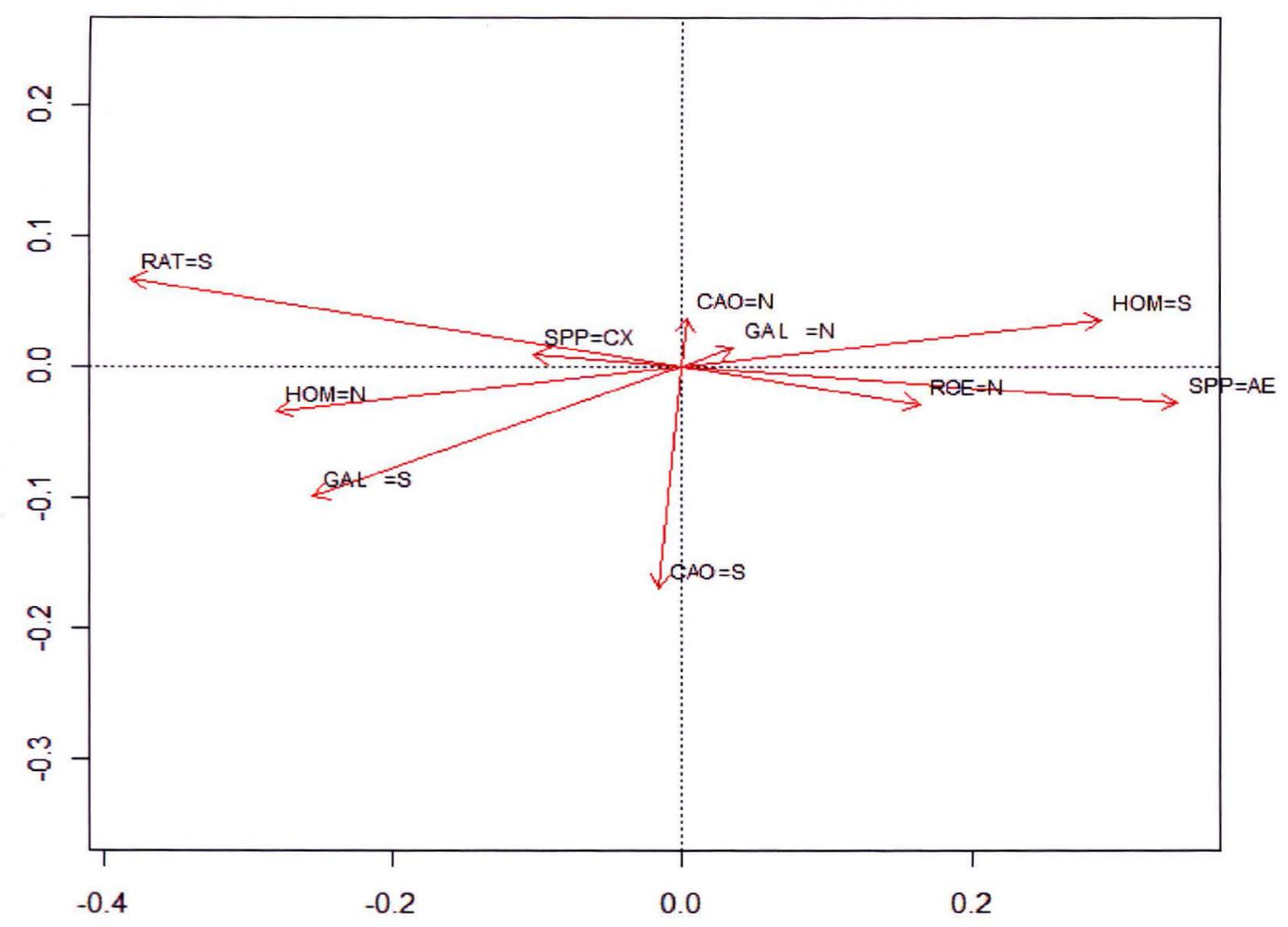

O resultado da aplicação da análise de correspondência ao conjunto das variáveis, constantes da tabela 3, é mostrado na Figura 12. Entre os fatores obtidos foram escolhidos os dois primeiros para representação da relação entre as variáveis, o fator 1 (horizontal), com 62,6\% da explicação da variação, e o fator 2 (vertical), com 17,0\% de explicação da variação total. $O$ fator 1 mostrou associação do Ae. aegypti (AE) com os escores do índice de condição de casa (ICC) iguais a 4, 7, 8 e 9 e com ingestão de apenas sangue 
humano (SO_HU); e do $C x$. quinquefasciatus com os escores 3, 5 e 6 do ICC, com ingestão de somente sangue de animal (SO_AN) e de animal e humano (HU_AN).

Em relação ao clima, o fator 1 mostrou associação do Ae. aegypti com o verão (VE), primavera (PR) e outono (OU); com o período chuvoso (CHU); e com os maiores níveis de temperaturas e umidade; e do $C x$. quinquefasciatus com o inverno (IN); com o período seco (SEC) e com os níveis de temperatura e umidade intermediários e mais baixos.

Figura 12 - Análise de correspondência das variáveis: espécie de mosquito (Ae. aegypti e Cx. quinquefasciatus), hábito alimentar, índice de condição de casa (ICC), local de encontro na residência (INT e PER), estação do ano, período seco ou chuvoso, temperaturas mínima, média e máxima e umidade média.

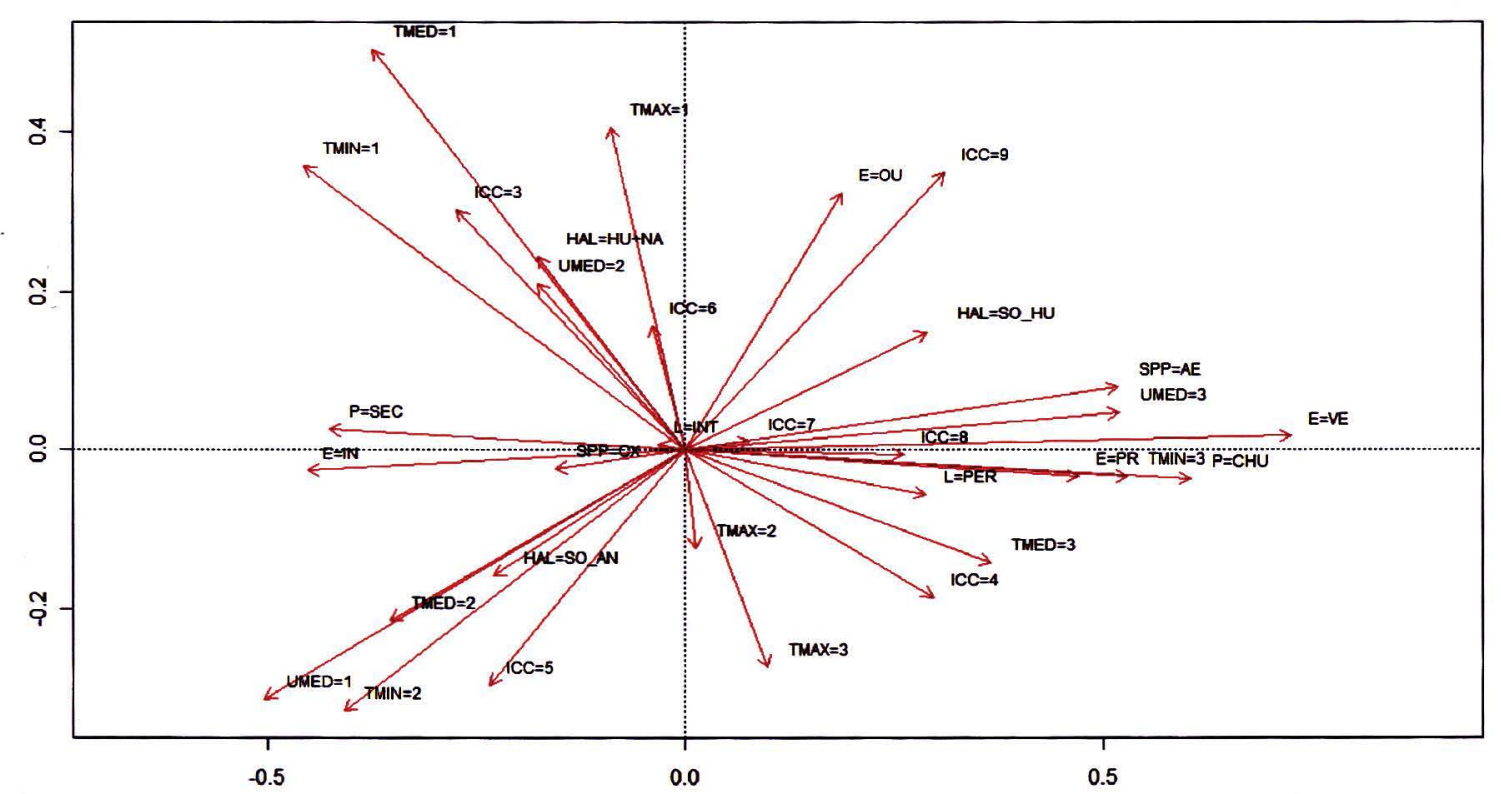

\subsection{AVALIAÇÃO DA CAPACIDADE REPRODUTIVA EM LABORATÓRIO}

5.2.1. Número de ovos postos por fêmeas de Ae. aegypti segundo repasto sanguíneo.

$\mathrm{Na}$ Figura 13, observa-se que a média de ovos postos por fêmea de Ae. aegypti alimentadas com sangue humano, de cão, ave e roedor, 
desconsiderando os dias de observação, apresentou variação. No entanto, a comparação dessas médias (ovos/sobreviventes), utilizando análise de variância não paramétrica, mostrou que não houve diferença significante entre elas $(H=4.8612 ; G L=3 ; p=0,182)$, no nível de $5 \%$.

Figura 13 - Média de ovos postos por fêmeas de Ae. aegypti após repasto sanguíneo de sangue humano, de cão, de galinha e de rato.

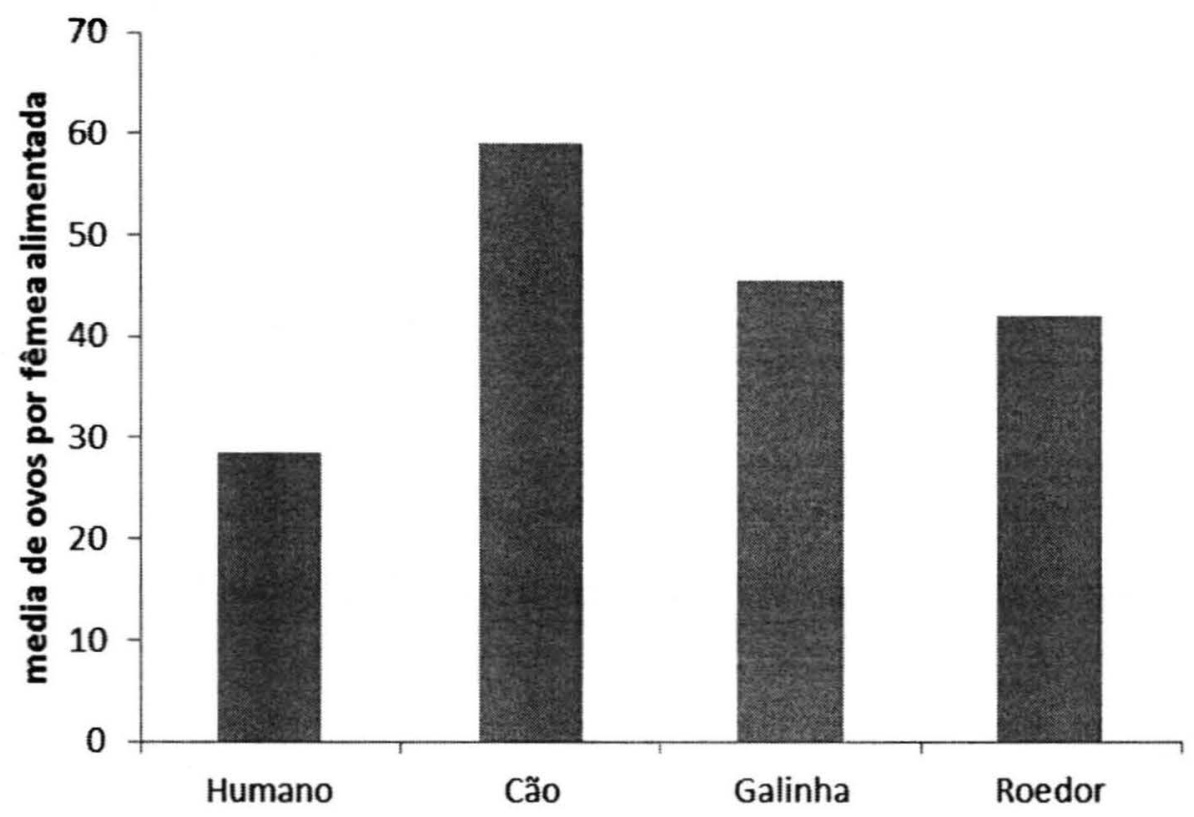


5.2.2. Média de ovos postos por fêmeas de Ae. aegypti alimentadas com sangue humano

Na Figura 14, observa-se que os valores mais altos para oviposição de fêmeas de Ae. aegypti ocorreu entre o $4^{2}$ e $\circ 7^{9}$ dias após o repasto com sangue humano, coincidindo com os percentuais mais altos de sobrevivência. O pico de oviposição é observado no $5^{2} \mathrm{dia}$. Notou-se que tanto a oviposição como a sobrevivência diminuiu ao longo dos dias de observação e mais intensamente a partir do $5^{0}$ dia.

Figura 14 - Média de ovos colocados por fêmea de Ae. aegypti após repasto sanguíneo humano e percentual de sobrevivência das mesmas.

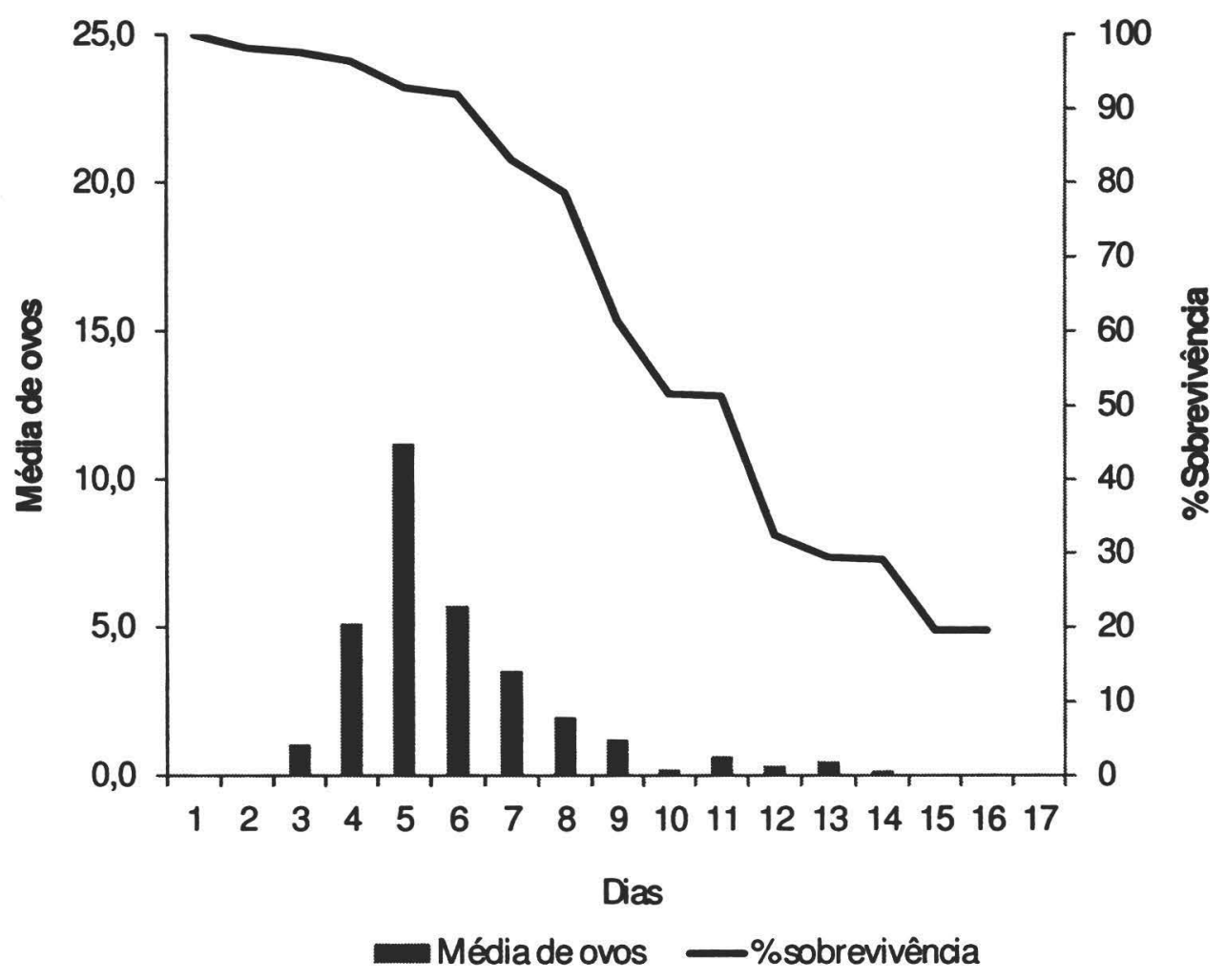


5.2.3. Fêmeas de Ae. aegypti alimentadas com sangue de cão

$\mathrm{Na}$ Figura 15, observa-se que os valores mais altos para oviposição de fêmeas de Ae. aegypti ocorreram entre o $4^{9}$ e $\circ 5^{9}$ dias após o repasto com sangue de cão e que a taxa de sobrevivência das fêmeas se manteve alta por todo o período de oviposição. O pico de oviposição foi observado no $4^{0}$ dia.

Figura 15 - Média de ovos colocados por fêmea de Ae. aegypti após repasto sanguíneo de cão e percentual de sobrevivência das mesmas.

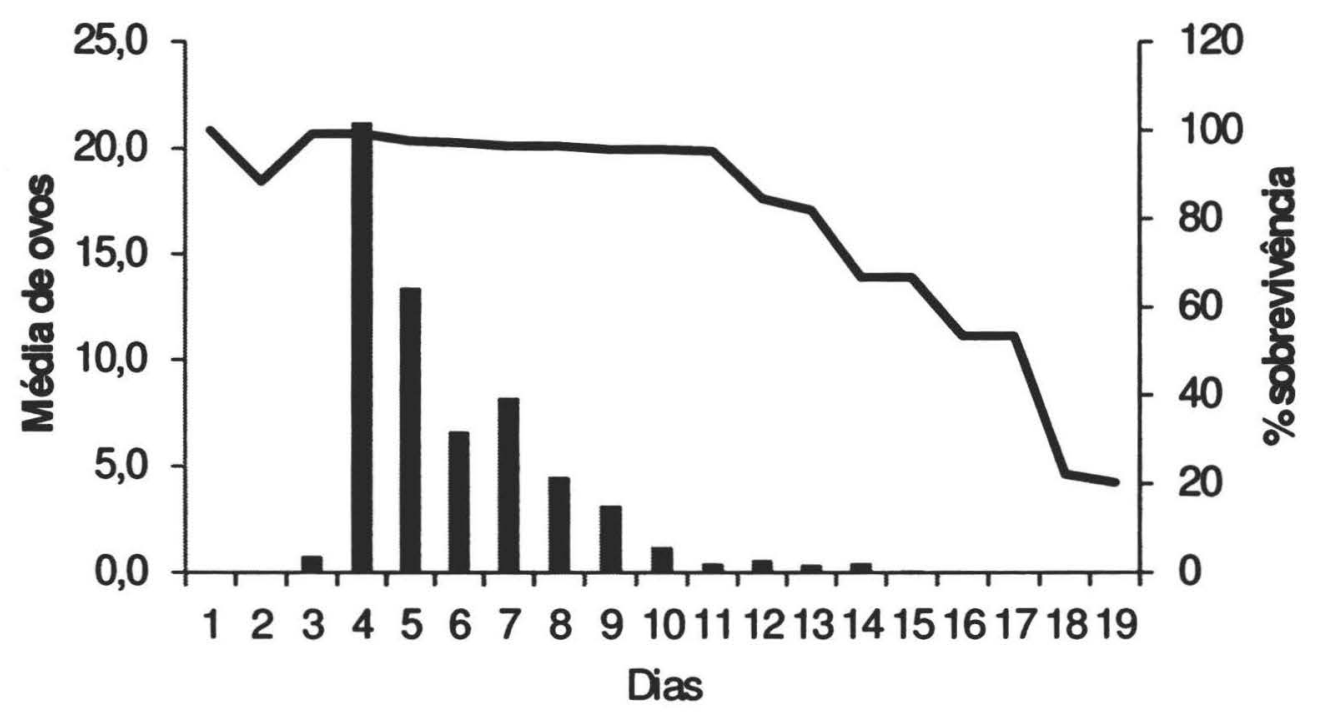

média ovos/fêmea —\%sobrevivência 
5.2.4. Fêmeas de Ae. aegypti alimentadas com sangue de Galinha

Na Figura 16, observa-se que os valores mais altos para oviposição de fêmeas de Ae. aegypti ocorreram entre o $4^{0}$ e o $5^{0}$ dias após o repasto com sangue de galinha e que a taxa de sobrevivência das fêmeas se manteve alta por todo o período de oviposição. O pico de oviposição foi observado no $4^{9}$ dia. O modelo de regressão do efeito do decorrer dos dias sobre a média de oviposição de fêmeas por sobreviventes mostrou que $28 \%\left(R^{2}=0,28\right.$, coeficiente de determinação) da variação da média de ovos postos por sobreviventes é explicada pelo efeito do decorrer dos dias.

Figura 16 - Média de ovos colocados por fêmea de Ae. aegypti após repasto sanguíneo de galinha e percentual de sobrevivência das mesmas.

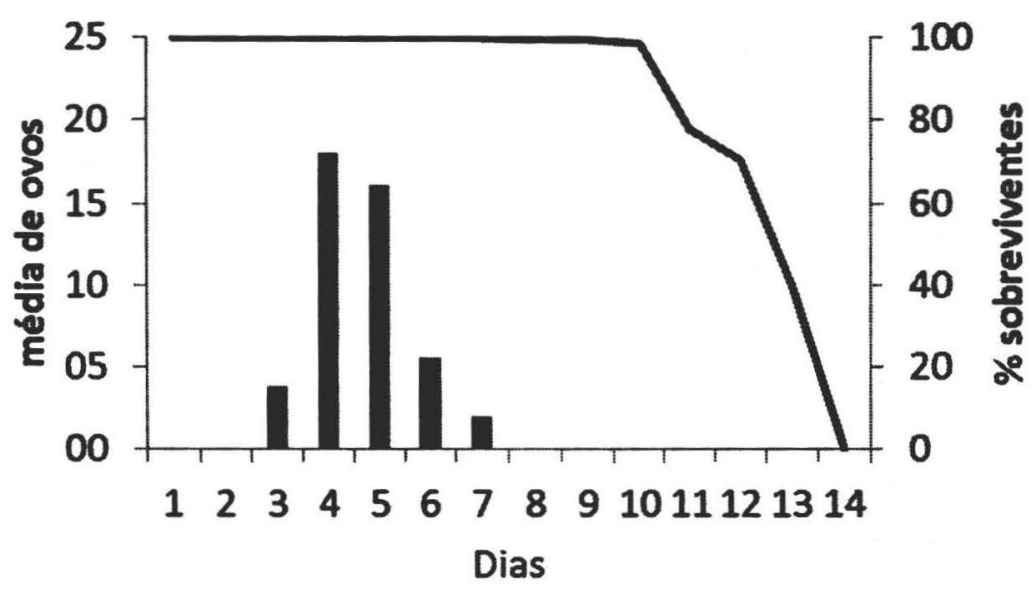

Média de ovos —\% sobreviventes 
$\mathrm{Na}$ Figura 17, observa-se que os valores mais altos para oviposição de fêmeas de Ae. aegypti ocorreram entre o $4^{\circ}$ e $\circ 5^{\circ}$ dias após o repasto com sangue de galinha e que a taxa de sobrevivência das fêmeas se manteve alta por todo o período de oviposição. O pico de oviposição foi observado no $4^{0}$ dia. O modelo de regressão do efeito do decorrer dos dias sobre a média de oviposição de fêmeas por sobreviventes mostrou que $16 \%\left(R^{2}=0,16\right)$, coeficiente de determinação) da variação da média de ovos postos por sobreviventes é explicada pelo efeito do decorrer dos dias.

Figura 17 - Média de ovos colocados por fêmea de Ae. aegypti após repasto sanguíneo, de roedor e percentual de sobrevivência das mesmas

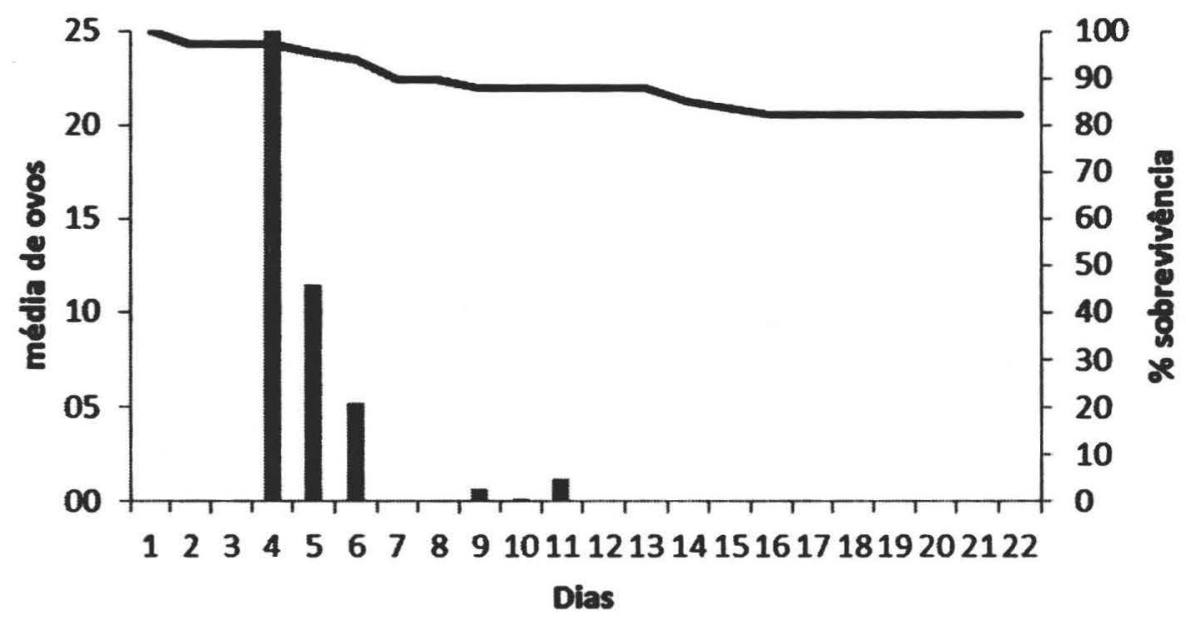

média de ovos sobrevivência 
5.2.5. Oviposição de fêmeas de $C x$. quinquefasciatus.

Na Figura 18, observa-se que a média de ovos postos por fêmea de Cx. quinquefasciatus alimentadas com sangue humano, de cão, de galinha e roedor, desconsiderando os dias de observação variou. No entanto, a comparação dessas médias (ovos/sobreviventes) utilizando análise de variância não paramétrica, mostrou que não houve diferença significante entre elas $(H=0.6283 ; G L=3 ; p=0,88)$, no nível de $5 \%$.

Figura 18 - Média de ovos postos por fêmeas de $C x$. quinquefasciatus após repasto sanguíneo humano, de cão, de galinha e roedor.

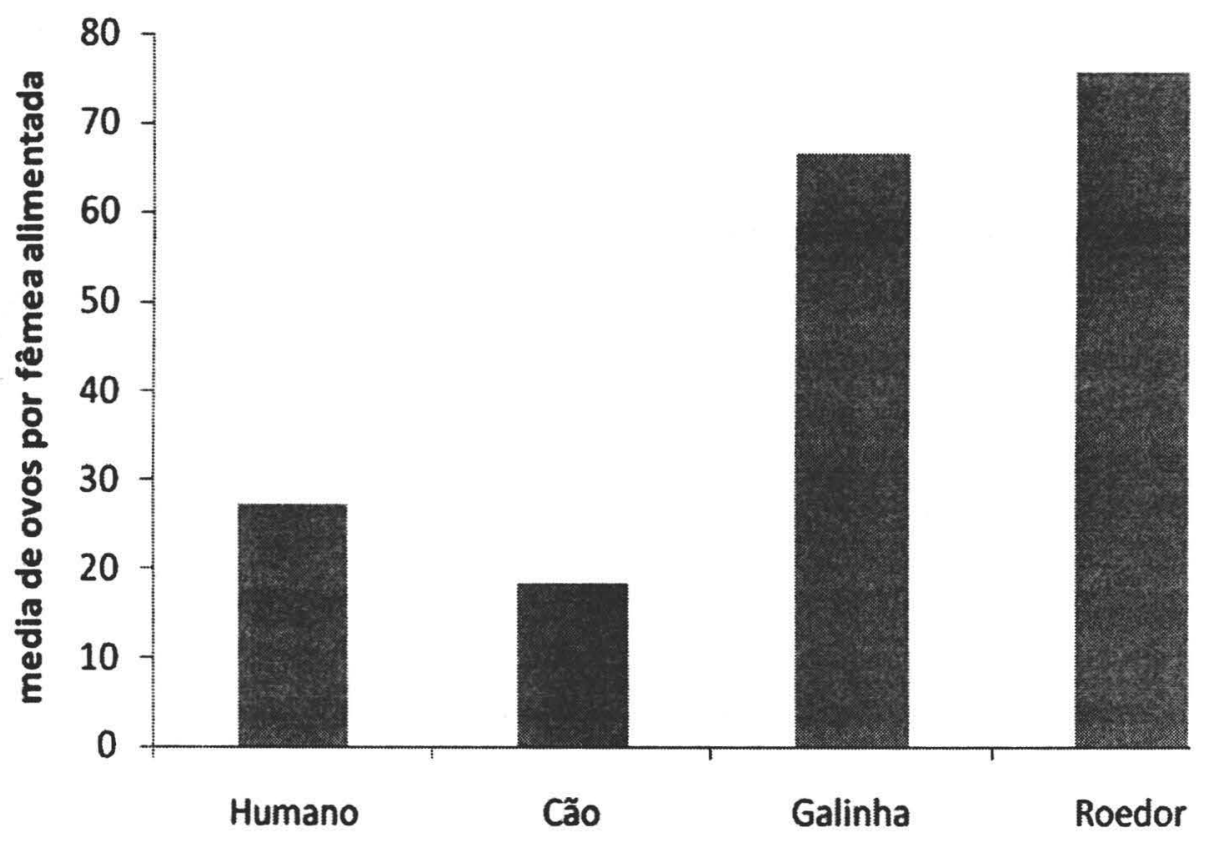


5.2.6. Fêmeas de Cx. quinquefasciatus alimentadas com sangue humano

$\mathrm{Na}$ Figura 19, observa-se que os valores mais altos para oviposição de fêmeas de $C x$. quinquefasciatus ocorreram entre $04^{2}$ e $05^{2}$ dias após 0 repasto com sangue humano, e que a taxa de sobrevivência das fêmeas se manteve alta por todo o período de oviposição. O pico de oviposição foi observado no $4^{\circ}$ dia.

Figura 19 - Média de ovos colocados por fêmea de $C x$. quinquefasciatus após repasto sanguíneo humano e percentual de sobrevivência das mesmas.

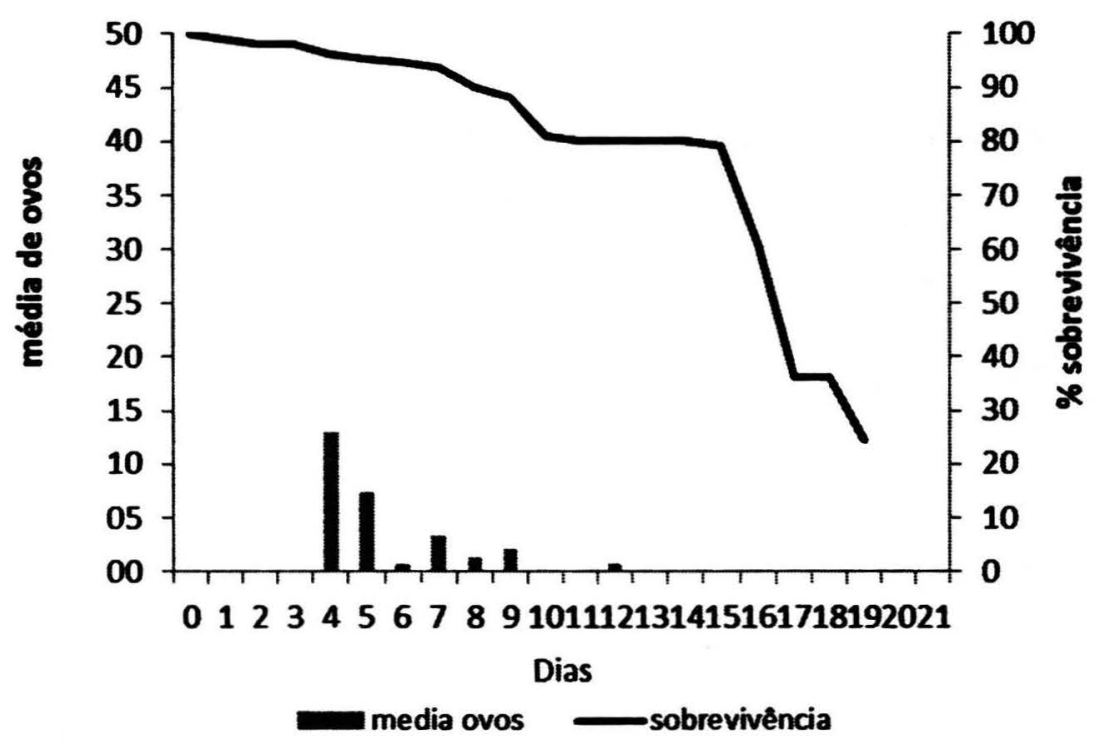


5.2.7. Fêmeas de $C x$. quinquefasciatus alimentadas com sangue de cão.

$\mathrm{Na}$ Figura 20, observa-se que os valores mais altos para oviposição de fêmeas de $C x$. quinquefasciatus ocorreram entre o $5^{0}$ e $\circ 6^{0}$ dias após 0 repasto com sangue canino e que a taxa de sobrevivência das fêmeas se manteve alta pela maior parte do período de oviposição. O pico de oviposição foi observado no $6^{\circ}$ dia.

Figura 20 - Média de ovos colocados por fêmea de $C x$. quinquefasciatus após repasto sanguíneo de cão e percentual de sobrevivência das mesmas.

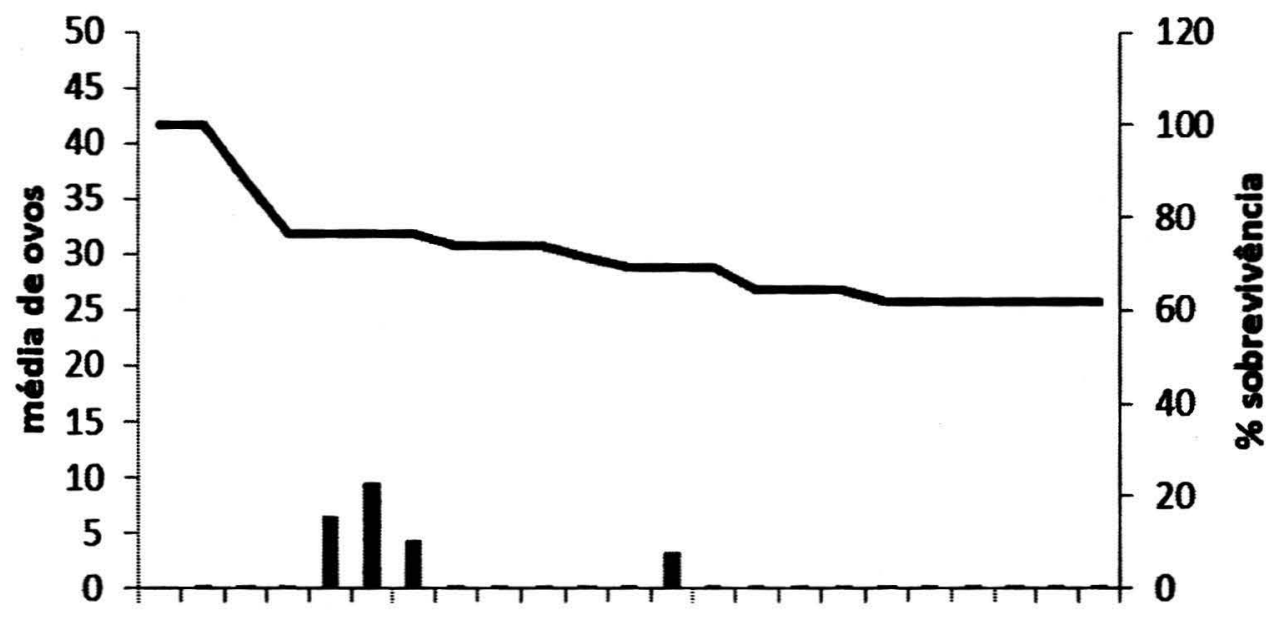

1234567891011121314151617181920212223

Dias

media de ovos 
5.2.8. Fêmeas de $C x$. quinquefasciatus alimentadas após repasto com sangue de galinha

$\mathrm{Na}$ Figura 21 observa-se que os valores mais altos para oviposição de fêmeas de $C x$. quinquefasciatus ocorreu entre o $3^{0}$ e $\circ 4^{0}$ dias após o repasto com sangue de galinha e que a taxa de sobrevivência das fêmeas se manteve alta pela maior parte do período de oviposição. O pico de oviposição foi observado no $3^{\circ}$ dia.

Figura 21 - Média de ovos colocados por fêmea de $C x$. quinquefasciatus após repasto sanguíneo de galinha e percentual de sobrevivência das mesmas.

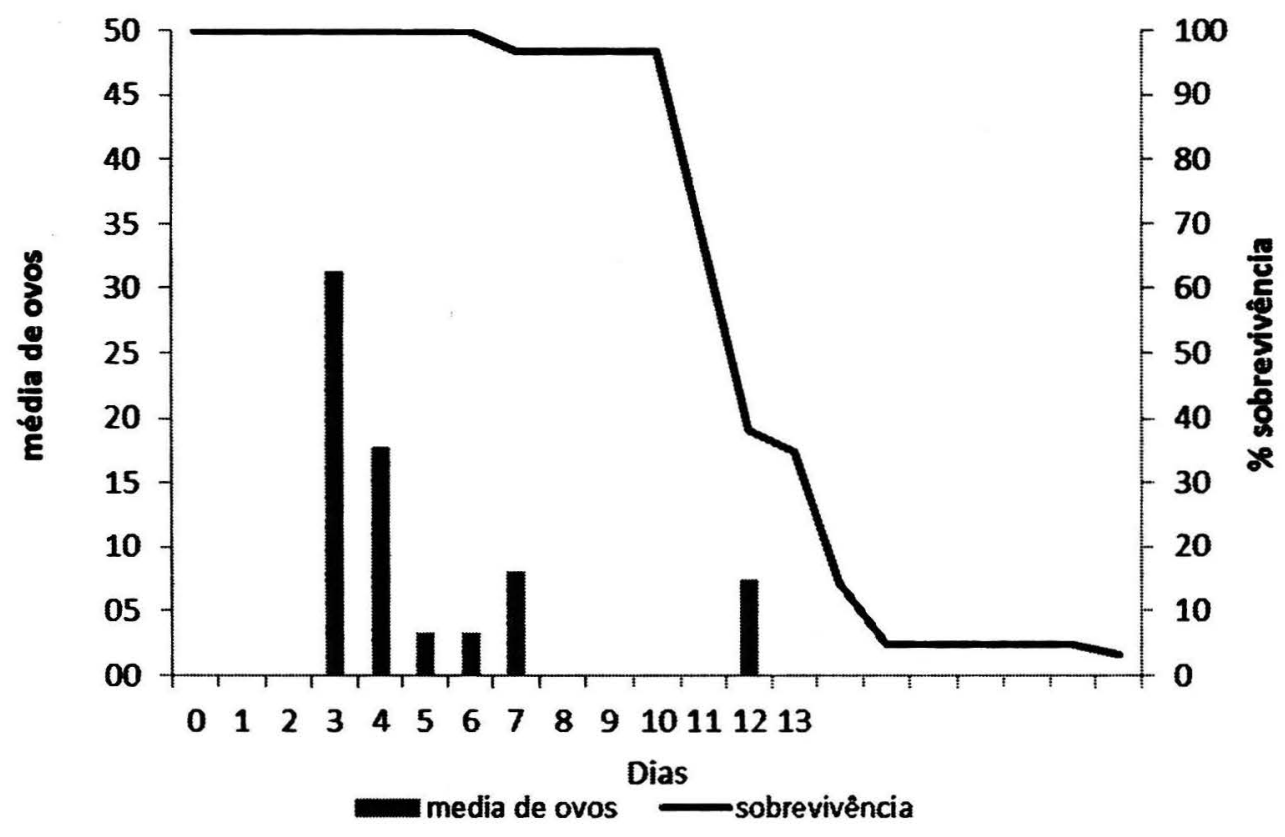


5.2.9. Fêmeas de Cx. quinquefasciatus alimentadas com sangue roedor

$\mathrm{Na}$ Figura 22, observa-se que os valores mais altos para oviposição de fêmeas de $C x$. quinquefasciatus ocorreram entre $02^{0}$ e $04^{\underline{9}}$ dias após 0 repasto com sangue de roedor e que a taxa de sobrevivência das fêmeas se manteve alta pela maior parte do período de oviposição. O pico de oviposição foi observado no $2^{\circ}$ dia.

Figura 22 - Média de ovos colocados por fêmea de $C x$. quinquefasciatus após repasto sanguíneo com sangue de roedor e percentual de sobrevivência das mesmas.

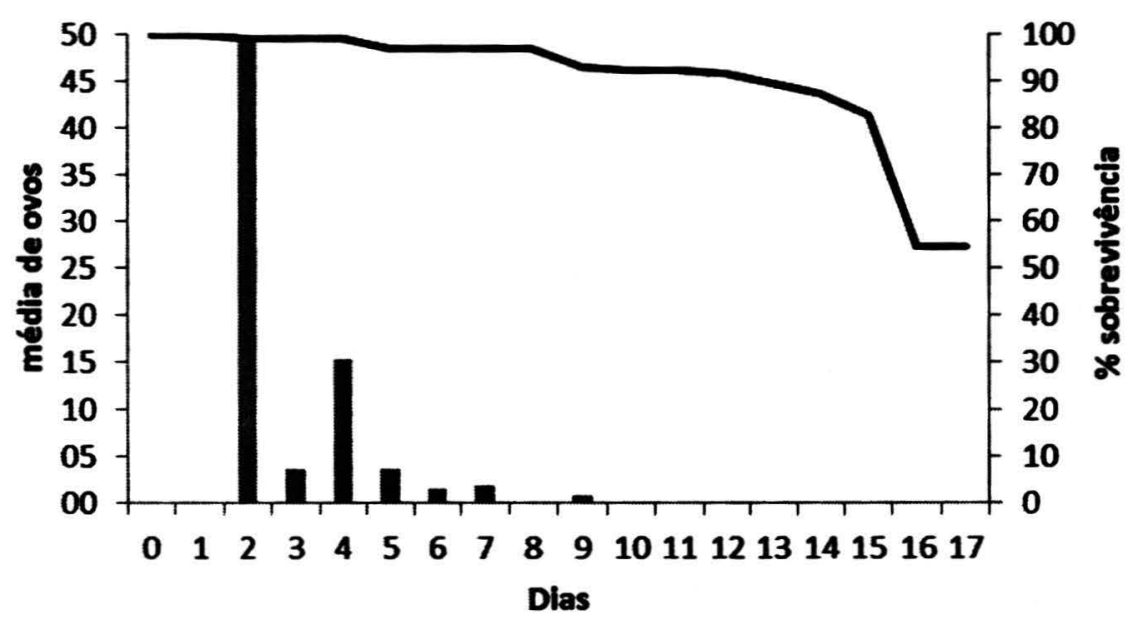


5.3. Observação do desenvolvimento de imaturos a partir de ovos (F1) de fêmeas de Ae. aegypti alimentadas com sangue humano, de cão e de galinha

O tempo de desenvolvimento das larvas de Ae. aegypti proveniente de ovos de fêmeas alimentadas de diferentes hospedeiros mostrou-se diferente. $O$ período correspondente no qual os ovos, oriundos de fêmeas alimentadas com sangue de cão, se transformaram em pupa foi menor do que os ovos provenientes de fêmeas alimentadas com sangue de humano e galinha (Figura 23). 
Figura 23 - Distribuição percentual da duração do período de ovo à pupa de espécimes de Ae. aegypti segundo fonte alimentar das fêmeas geradoras humano, cão e ave.
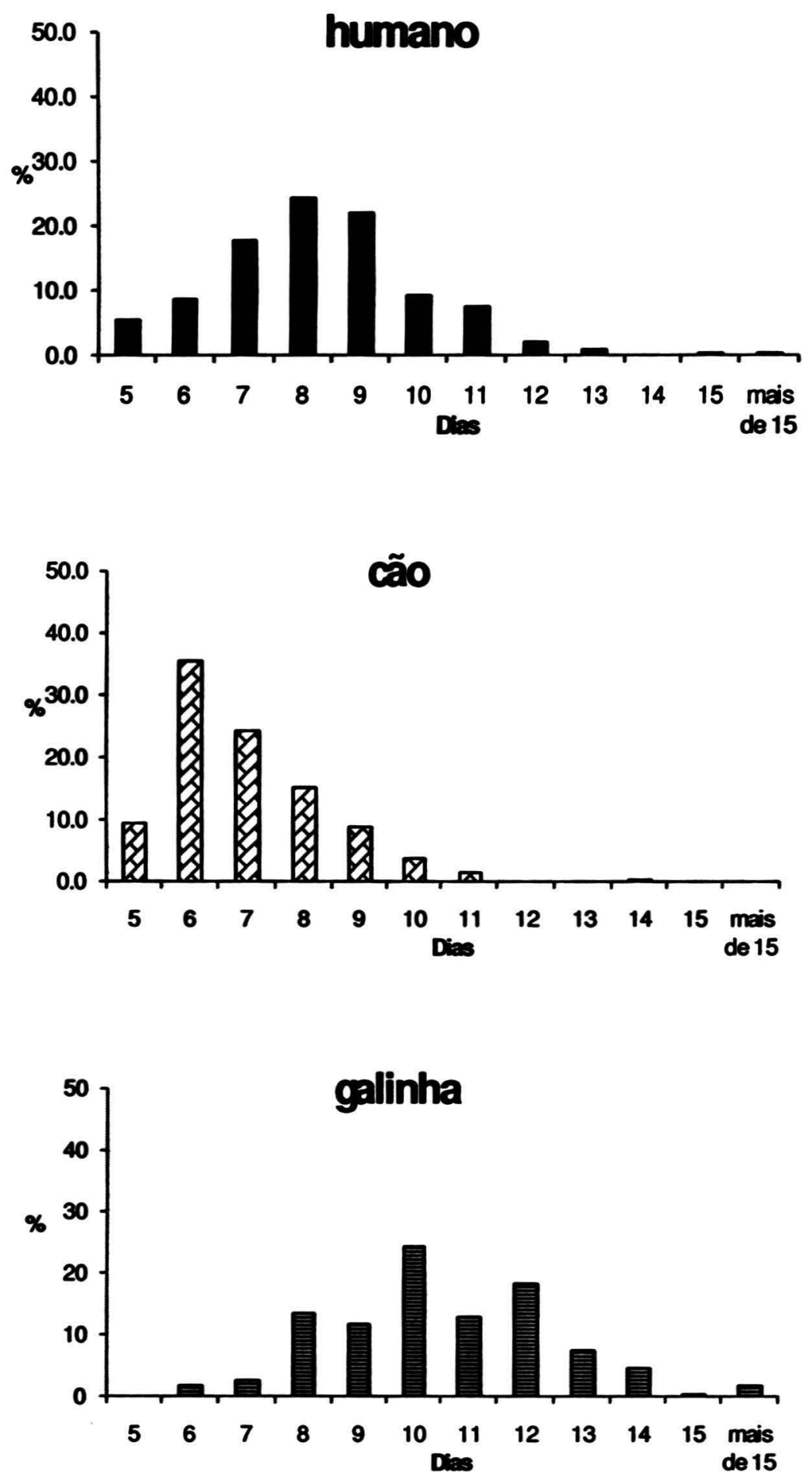
A. Observação do desenvolvimento de imaturos a partir de ovos (F1) de fêmeas de Ae. aegypti alimentadas com sangue humano.

O modelo univariado da variação do percentual de eclosão de adultos (\% pupação), proveniente de larvas oriundas de ovos de fêmeas de Ae. aegypti alimentadas previamente com sangue humano ao longo do período de desenvolvimento não foi bom (Figura 24), apesar de $\beta_{1}$ ser diferente de zero $(0,03)$, esta variação não foi significante $(F=0.8584 ; p=0.6210)$. $O$ coeficiente de determinação $\left(R^{2}=0.0130\right)$ foi praticamente zero e a correlação entre as variáveis foi baixa (0.28) (Figura 24).

Figura 24 - Percentual de ovos de Ae. aegypti, alimentadas com sangue humano, que se desenvolveram até o estágio de pupa.

Teste de Regressão Linear (Humano)

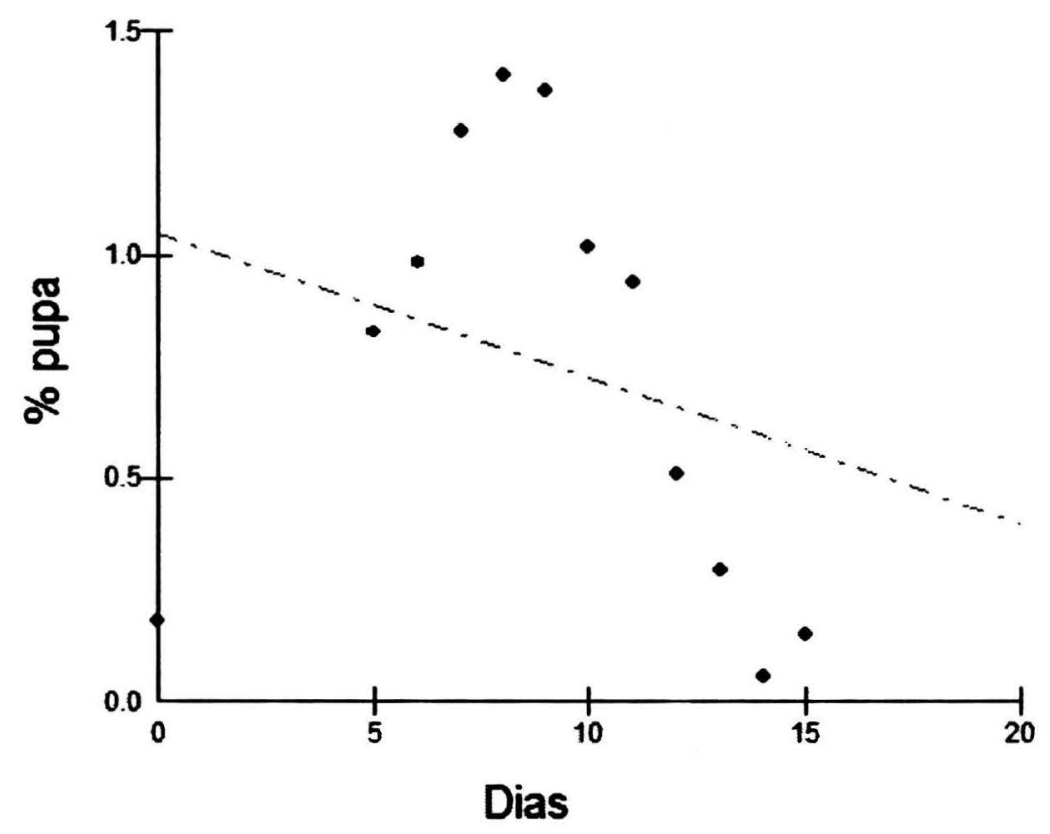

Equação da reta foi $Y=1.05-0.03 X$ 
B. Observação do desenvolvimento de imaturos a partir de ovos (F1) de fêmeas de Ae. aegypti alimentadas com sangue de cão.

O modelo da variação do percentual de eclosão de adultos (\% pupação) proveniente de lanas oriundas de ovos de fêmeas de Ae. aegypti alimentadas previamente com sangue de cão ao longo do período de desenvolvimento foi bom (Figura 25) ( $\beta_{1}$ diferente de zero). Observou-se que $84 \%\left(R^{2}=0.84\right)$ da variação desse percentual foi explicado ao longo do período de desenvolvimento a partir do momento que as fêmeas da geração F1 receberam sangue canino. Esta variação foi significante $(F=47.7040$; $\mathrm{p}=0.0002$ ). Ao longo do período de desenvolvimento houve uma diminuição no percentual de pupação $\left(\beta_{1}=-0.1601\right)$. Equação da reta foi $Y=2.2919-$ $0.1601 X$.

Figura 25 - Percentual de ovos de Ae. aegypti, alimentadas com sangue de cão, que se desenvolveram até o estágio de pupa.

Teste de Regressão Linear (Cão)

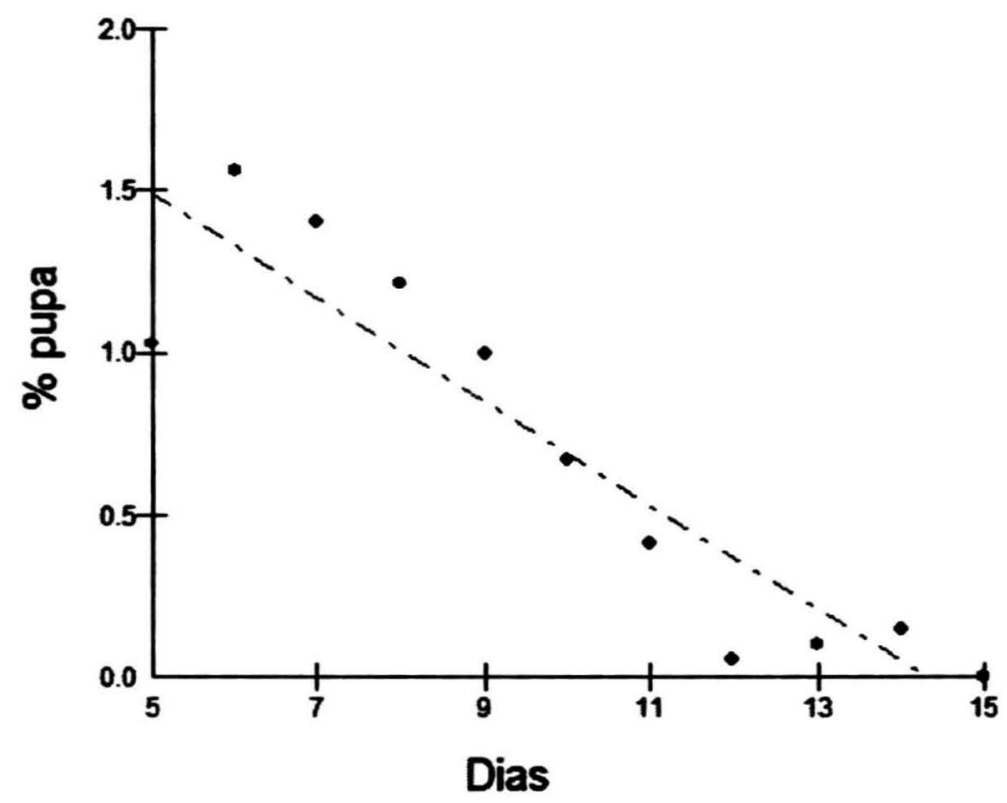


C. Observação do desenvolvimento de imaturos a partir de ovos (F1) de fêmeas de Ae. aegypti alimentadas com sangue de galinha.

0 modelo da variação do percentual de eclosão de adultos (\% pupação) proveniente de larvas oriundas de ovos de fêmeas de Ae. aegypti alimentadas previamente com sangue de galinha ao longo do período de desenvolvimento não foi bom (Figura 26), $x$ não explica $y$, apesar de $\beta_{1}$ ser diferente de zero $(0,03)$. Esta variação não foi significante $(F=0.4715$; $p=0.5151$ ). Equação da reta foi $Y=0.4980-0.03 X$. O coeficiente de determinação $\left(R^{2}=0,05\right)$ foi praticamente zero e a correlação entre as variáveis foi baixa (0.22).

Figura 26 - Percentual de ovos de Ae. aegypti, alimentadas com sangue de galinha, que se desenvolveram até o estágio de pupa.

Teste de Regressafo Linear (Galinha)

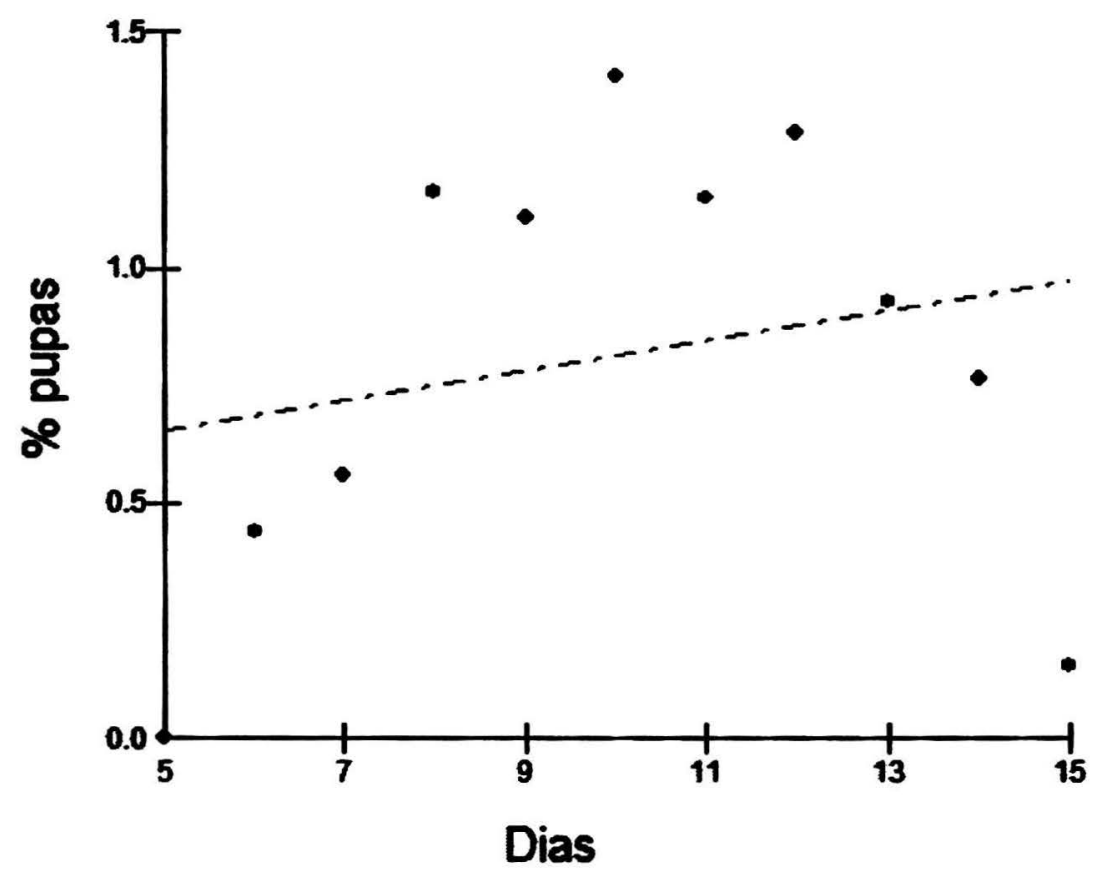


Finalizando, o modelo multivariado do percentual de eclosão de adultos (\% pupação) de Ae. aegypti ao longo do período de desenvolvimento foi bom. Esta variação foi significante $(F=87.50 ; p=0.0002)$. $O$ coeficiente de determinação $\left(R^{2}=0.97\right)$ e a correlação entre as variáveis foi de 0.99 .

5.4. Observação do desenvolvimento de imaturos a partir de ovos (F1) provenientes de fêmeas de $C x$. quinquefasciatus alimentadas com sangue humano, de galinha e de roedor

O tempo de desenvolvimento das larvas de $C x$. quinquefascistus proveniente de ovos de fêmeas alimentadas com sangue humano, de galinha, cão e roedor mostrou-se diferente. $O$ período que corresponde ao desenvolvimento dos ovos oriundos de fêmeas alimentadas com sangue humano até o estágio de pupa, foi menor do que o período de ovos provenientes de fêmeas alimentadas com sangue de humano e galinha (Figura 27). 
Figura 27 - Distribuição percentual da duração do período de ovo à pupa de espécimes de $C x$. quinquefasciatus segundo fonte alimentar das fêmeas geradoras A) humano, B) cão e C) ave.
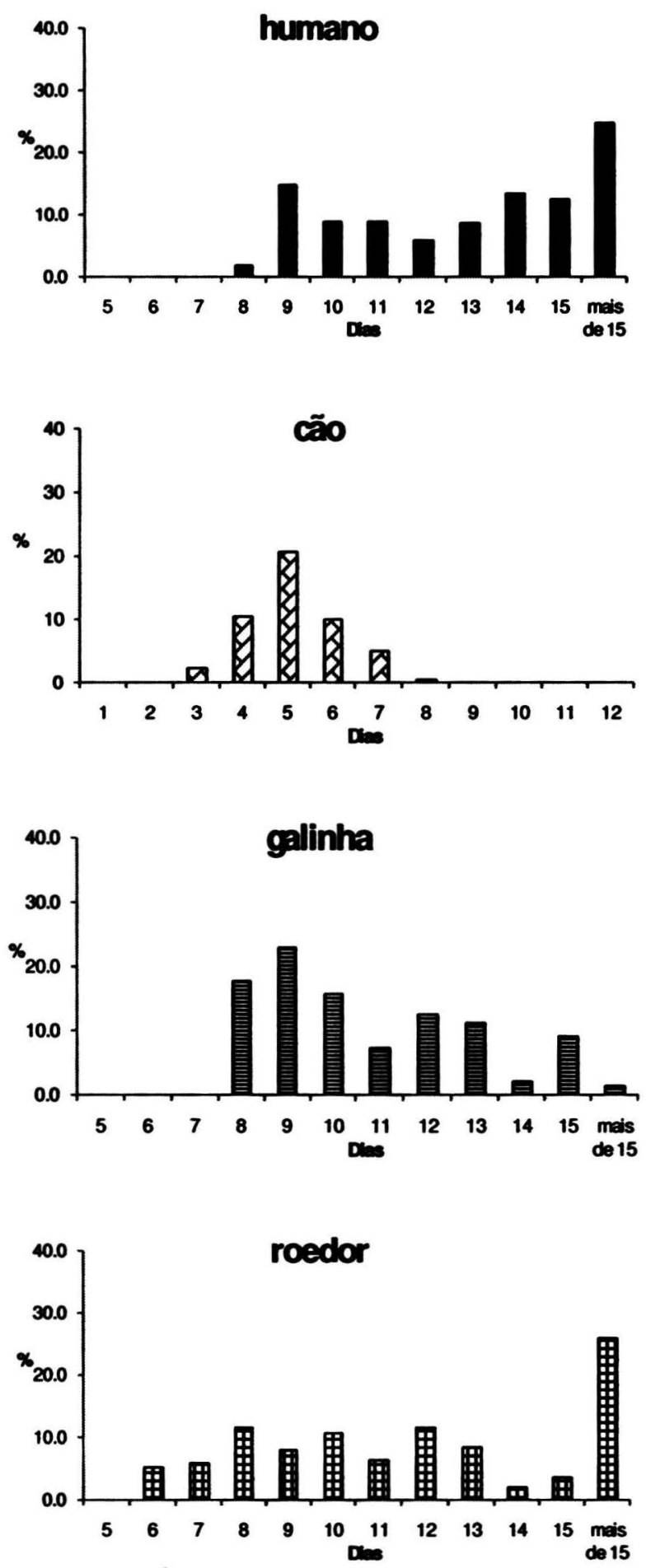
A. Observação do desenvolvimento de imaturos a partir de ovos (F1) de fêmeas de $\mathrm{Cx}$. quinquefasciatus alimentadas com sangue humano.

O modelo univariado da variação do percentual de eclosão de adultos (\% pupação) proveniente de larvas oriundas de ovos de fêmeas de $C x$. quinquefasciatus alimentadas previamente com sangue humano, ao longo do período de desenvolvimento foi bom (Figura 28$),\left(\beta_{1} \neq\right.$ zero). Observou-se que $62 \%\left(R^{2}=0.62\right)$ da variação desse percentual é explicado ao longo do período de desenvolvimento a partir do momento que as fêmeas da geração $F 1$ receberam sangue humano. Esta variação foi significante $(F=18.9473 ; p=$ 0.0017). Ao longo do período de desenvolvimento houve uma diminuição no percentual de pupação $\left(\beta_{1}=-0.1198\right)$.

Figura 28 - Percentual de ovos de fêmeas de $C x$. quinquefasciatus, alimentadas com sangue humano, que se desenvolveram até o estágio de pupa.

\section{Teste de Regressão Linear ovos de fêmeas de Cx alimentadas sangue Humano}

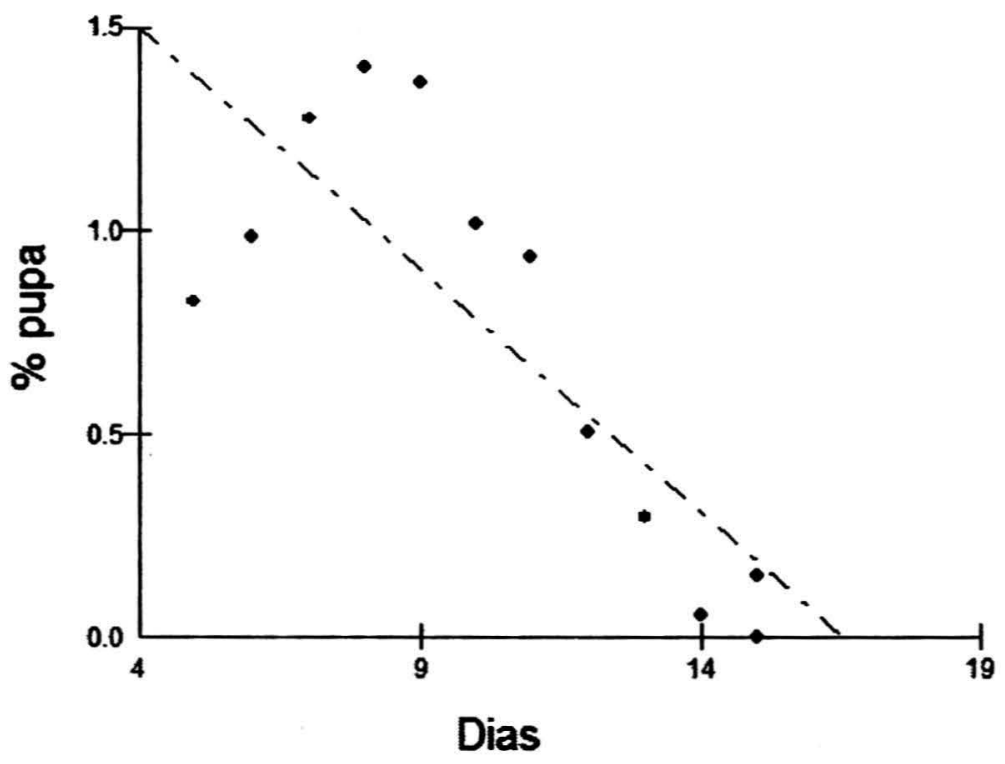

Equação da reta: $Y=1.98-0.12 x$ 
B. Observação do desenvolvimento de imaturos a partir de ovos (F1) de fêmeas de Cx. quinquefasciatus alimentadas com sangue de cão.

O modelo univariado da variação do percentual de eclosão de adultos (\% pupação) proveniente de larvas oriundas de ovos de fêmeas de $C x$. quinquefasciatus alimentadas com sangue de cão, ao longo do período de desenvolvimento não foi bom, apesar de $\beta_{1}$ ser diferente de zero, esta variação não foi significante $(F=0.98 \quad p=0.65)$. Ao longo do período de desenvolvimento houve uma diminuição no percentual de pupação $(\beta 1=-0.044)$. $O$ coeficiente de determinação $\left(R^{2}=0.09\right)$ foi praticamente zero e a correlação entre as variáveis foi 0.30 (Figura 29).

Figura 29 - Percentual de ovos de fêmeas de $C x$. quinquefasciatus, alimentadas com sangue de cão, que se desenvolveram até o estágio de pupa.

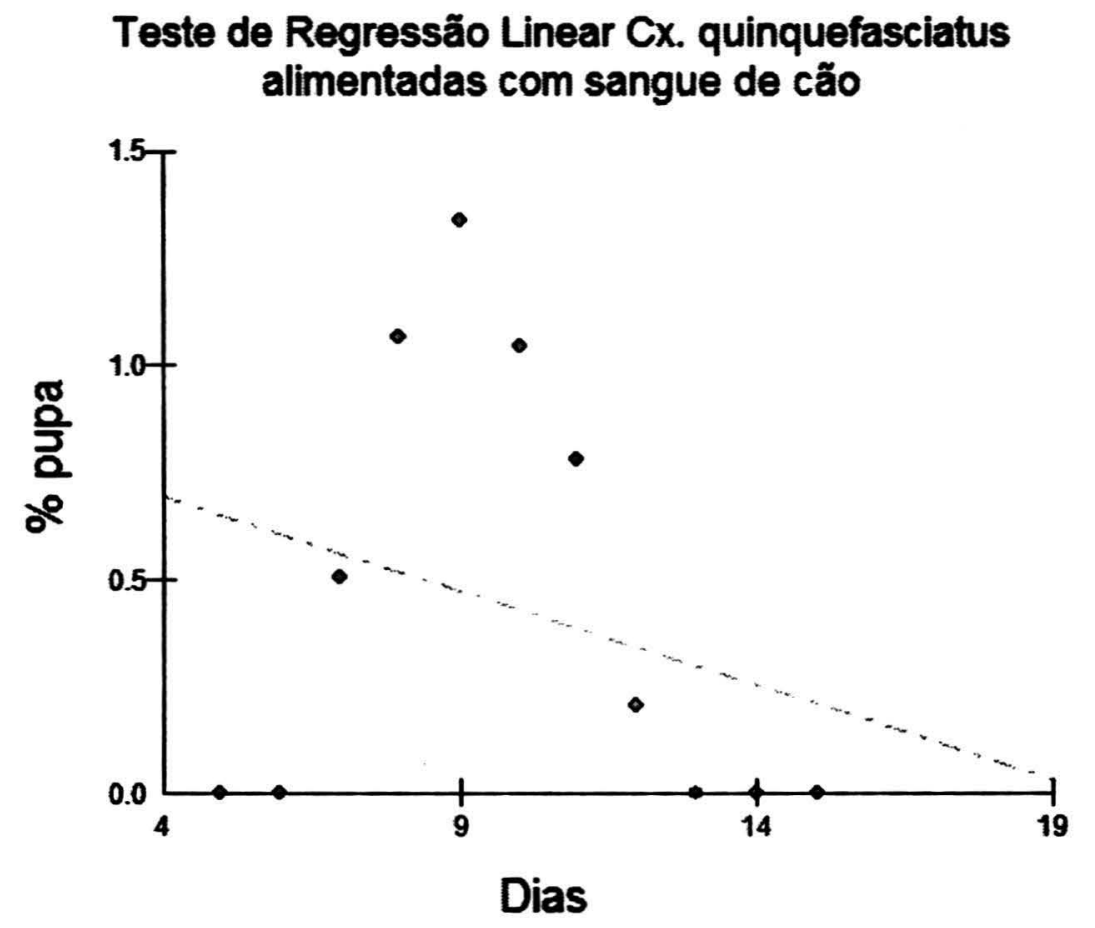

Equação da reta foi $Y=0,869-0,044 x$ 
C. Observação do desenvolvimento de imaturos a partir de ovos (F1) de fêmeas de $\mathrm{Cx}$. quinquefasciatus alimentadas com sangue de galinha.

O modelo univariado da variação do percentual de eclosão de adultos (\% pupação) proveniente de larvas oriundas de ovos de fêmeas de $C x$ quinquefasciatus previamente alimentadas com sangue de galinha, ao longo do período de desenvolvimento não foi boa (Figura 30 ), apesar de $\beta_{1}$ ser diferente de zero $(0,10)$. Esta variação não foi significante $(F=0.0017 ; p=0.9666)$. $O$ coeficiente de determinação $\left(R^{2}=0.0002\right)$ foi praticamente zero e a correlação entre as variáveis foi baixa 0.0226 .

Figura 30 - Percentual de ovos de fêmeas de $C x$. quinquefasciatus, alimentadas com sangue de galinha, que se desenvolveram até o estágio de pupa.

Teste de Regressão Linear ovos de fêmeas de Cx alimentadas com sangue de galinha

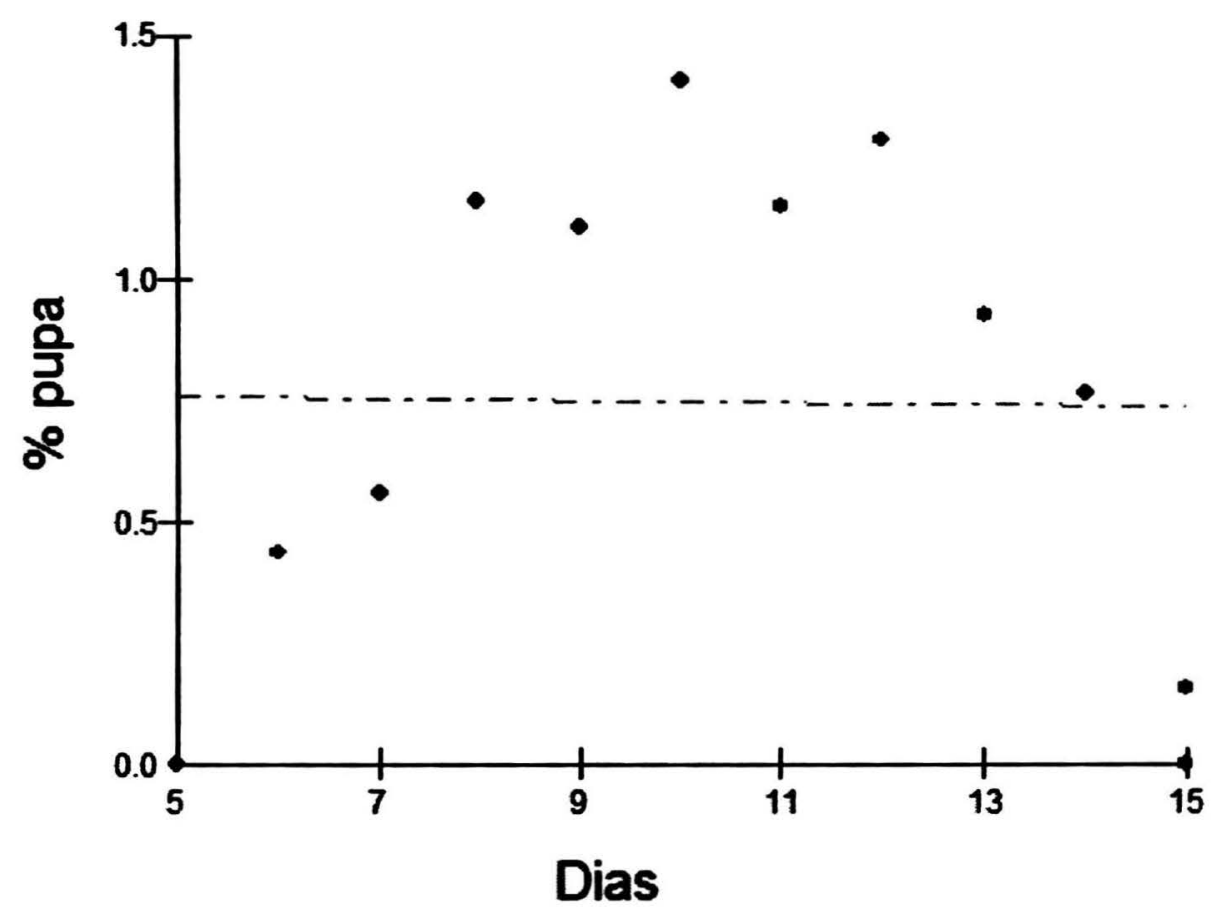

Equação da reta foi $Y=0.77-0.002 X$. 
D. Observação do desenvolvimento de imaturos a partir de ovos (F1) de fêmeas de $\mathrm{Cx}$. quinquefasciatus alimentadas com sangue de roedor.

O modelo univariado da variação do percentual de eclosão de adultos (\% pupação) provenientes de larvas oriundas de ovos de fêmeas de $C x$ quinquefasciatus, previamente alimentadas com sangue de roedor, ao longo do período de desenvolvimento não foi bom (Figura 31), apesar de $\beta_{1}$ ser diferente de zero $(-0.0091)$. Esta variação não foi significante $\left(R^{2}=0.0066 ; p=0.7966\right)$. O coeficiente de determinação $\left(R^{2}=0.0066\right)$ foi praticamente zero e a correlação entre as variáveis foi baixa 0.0813 .

Figura 31 - Percentual de ovos de fêmeas de Cx. quinquefasciatus, alimentadas com sangue de roedor, que se desenvolveram até o estadio de pupa.

\section{Teste de Regressão Linear ovos de fêmeas de \\ Cx alimentadas com sangue de roedor}

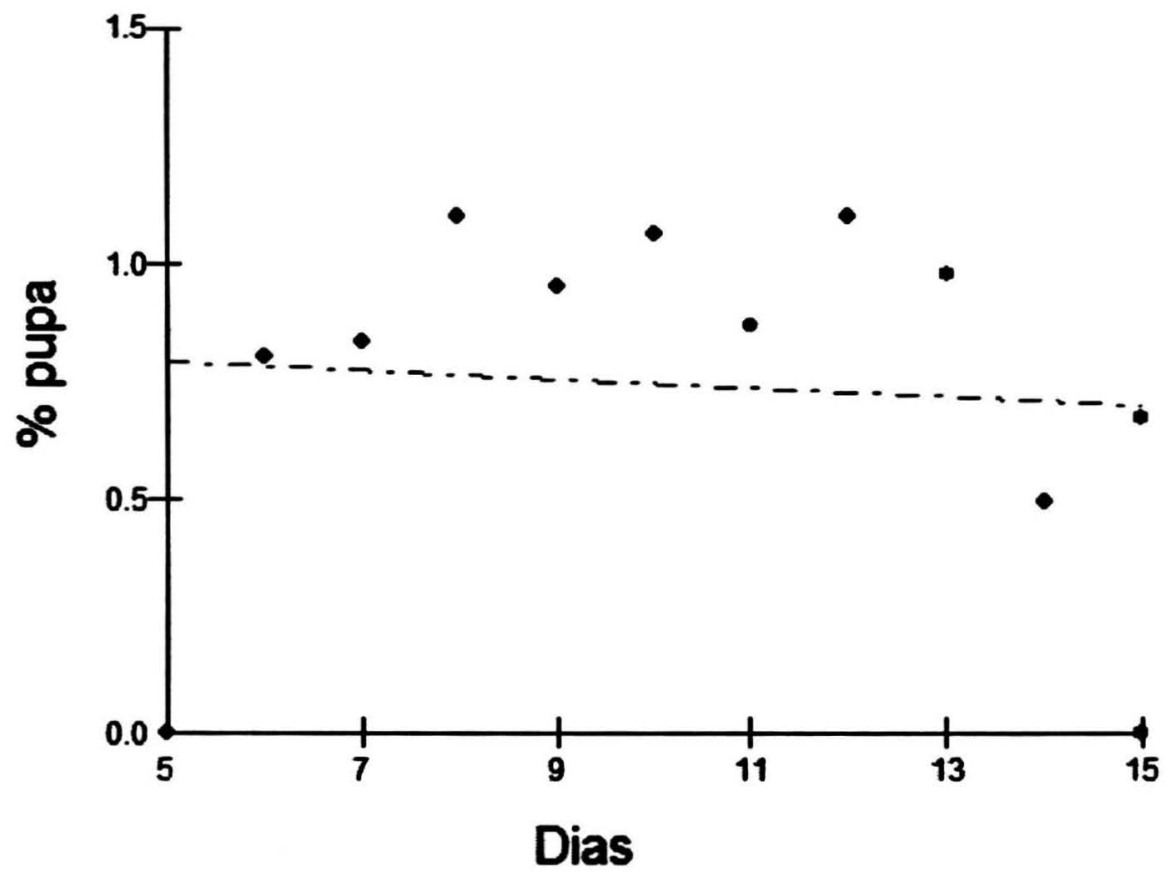

Equação da reta: $Y=0.8346-0.0091$

O modelo multivariado da variação do percentual de eclosão de adultos (\% pupação) de Culex quinquefasciatus ao longo do período de 
desenvolvimento foi bom (Figura 33). Esta variação foi significante ( $F=24,9$ 5; $p=0.0007)$. $O$ coeficiente de determinação $(R 2=0.93)$ e a correlação entre as variáveis foi de 0.97 . 


\section{DISCUSSÃO}

O resultado deste trabalho realizado em duas etapas, de campo e laboratório, tentou responder lacunas do conhecimento em relação ao hábito alimentar de fêmeas de espécies de mosquitos Culicidae adaptadas ao ambiente urbano. Em laboratório tentou-se reproduzir as mesmas fontes de alimentação observadas em campo objetivando verificar se havia um benefício na capacidade reprodutiva quando as fêmeas se alimentavam de fontes diferentes de hospedeiros.

\subsection{IDENTIFICAÇÃO DO HÁBITO ALIMENTAR PELO ELISA DE FÊMEAS COLETADAS EM CAMPO}

O teste ELISA possibilita a identificação de fonte sanguínea, com especificidade ao nível de gênero e sensibilidade que requer apenas repastos sanguíneos parciais. Sua automação permite o processamento e investigação de um grande número de amostras, o que representa um aspecto de importância numa investigação epidemiológica (BURKOT et al., 1981).

Conforme referido anteriormente, tal método foi previamente padronizado por Vicentim (2005), que verificou sua elevada sensibilidade através da mensuração do volume de sangue presente no abdômen de Aedes scapularis. Nestes, o teste ELISA indireto foi capaz de detectar $0,125 \mu$ de sangue presente em seu abdômen, comprovando a alta sensibilidade da reação. Neste mesmo estudo, para garantir a inexistência de reações cruzadas entre os testes, padronizou-se para cada anti-soro, sua concentração ótima, ou seja, aquela onde não há risco do sangue estar reagindo com mais de um antisoro inespecificamente.

O teste ELISA de captura foi inicialmente utilizando por meio do emprego de anti-lgG das respectivas fontes alimentares com anticorpos policlonais. Contudo, os resultados obtidos quando da pesquisa de sangue ingerido proveniente de hospedeiros evolutivamente próximos, tal como 
humanos e macacos, produziram reações cruzadas. Posteriormente, o emprego de anticorpos monoclonais, propiciou sensível diminuição da possibilidade de encontro de reações cruzadas entre hospedeiros próximos, elevando a especificidade do teste (SERVICE et al., 1986). Neste estudo com fêmeas capturadas no município de Marília (SP), foram utilizados anticorpos monoclonais, representados pelos anti-soros de cada um dos hospedeiros em questão.

Ínfima quantidade de sangue detectava pelo ELISA no abdômen de fêmeas indicam a capacidade do teste identificar o material ingerido após várias horas do repasto sanguíneo. Desta forma, o critério adotado neste estudo em Marília de não seleção prévia de fêmeas de Ae. aegypti e $C x$. quinquefasciatus para verificação de volume de sangue (estádio de Sella) obtido após repasto, se justifica em virtude da possibilidade de exclusão de fêmeas consideradas não ingurgitadas ao nível do microscópio.

Segundo Chow et al. (1993), a determinação da fonte alimentar do sangue ingerido pelo mosquito depende principalmente da taxa de digestão do mesmo, que em países tropicais, geralmente ocorre entre 24 e 48 horas. Contudo, o volume de sangue ingerido e a espécie de mosquito estudada também influenciam na identificação dos hospedeiros envolvidos. Neste estudo, foram utilizados mosquitos capturados em campo, portanto o tempo de digestão do repasto sanguíneo é desconhecido.

Conforme mostrado na Tabela 3, as 913 fêmeas pertencem à apenas quatro espécies: Ae. aegypti, Cx.quinquefasciatus., Ae.albopictus. e Ae. scapularis. Espécies essas conhecidamente associadas a modificações antrópica em ambiente urbano. Devido à baixa riqueza de espécies verificadas nos 260 setores censitários do município de Marília, optou-se por centrar a análise dos dados e discussão nas duas espécies mais abundantes (percentualmente mais expressivas): $C x$. quinquefasciatus e Ae. aegypti.

De todas as fêmeas capturadas (ainda incluindo Ae. albopictus e Ae. scapularis), em 390 identificou-se ao menos um repasto sanguíneo e em 523 exemplares não se identificou nenhum repasto para os hospedeiros testados. Os resultados das amostras não reagentes poderiam ser atribuídos a outras 
fontes sanguíneas que não foram incluídas no ensaio imunoenzimático ou devido ao processo digestivo encontrar-se em fase avança de absorção.

A Figura 7 revela que a grande maioria das fêmeas de $A e$. aegypti e $C x$. quinquefasciatus obtém repastos em um único hospedeiro. Dentre as fêmeas de ambas as espécies estudadas que realizaram repasto único, pode-se verificar na Figura 8, que a maior frequência de fêmeas de $A e$. aegypti alimentadas pelo sangue humano $(73,1 \%)$ era esperada devido à sua conhecida antropofília e domiciliação (FORATTINI, 2002). A segunda fonte alimentar mais frequente da referida espécie foi o cão $(21,8 \%)$. Chamou atenção a frequencia semelhante das fontes alimentares homem $(30,6 \%)$ e rato $(38,7 \%)$ identificada nas fêmeas de Cx.quinquefasciatus. Provavelmente, isso se deve ao fato de que os mosquitos desta espécie poder encontrar alimento abrigado próximo aos seus criadouros, como por exemplo, os esgotos. Todavia os ratos também costumam frequentar os peridomicílios. O teste ELISA também revelou um percentual de fêmeas de culicídeos que realizaram repastos múltiplos. Esses resultados corroboraram com os obtidos por vários autores em diferentes localidades de estudo (Forattini et al., 1981, 1987,1989; Hervé e Rosa, 1983; Mitchell et al., 1987; Lourenço de Oliveira e Heyden 1986; Gomes et al., 2003).

Como indica a Figura 9, fêmeas de Ae. aegypti, realizaram preferencialmente repastos em homem e rato $(4,7 \%$ - 04/86), com menor percentual em homem e cão $(2,3 \%-02 / 86)$, enquanto que fêmeas de $C x$. quinquefasciatus, o fizeram preferencialmente em homem e cão $(5 \%$ - 15/295), com percentuais menores em homem e rato e cão e rato $(3,4 \%-10 / 295$ para cada um deles). Contudo, no que diz respeito às fêmeas de $C x$. quinquefasciatus, apesar dos baixíssimos percentuais encontrados dentre as fêmeas que fizeram repastos múltiplos, elas o realizaram em todos os hospedeiros em questão, denotando o ecletismo desta espécie quanto ao hábito alimentar (FORATTINI, 1987; 2002; CASTEX et al., 1990). As fêmeas de Ae. aegypti, em contrapartida, não realizaram repastos múltiplos em homem e galinha e cão e galinha. 
No que diz respeito à multiplicidade de repastos sanguíneos, sabe-se que é necessário que estes aconteçam a fim de propiciar a maturação de ovos em populações de aedíneos e anofelinos (GILLIES,1954, 1955). Além disso, quanto mais repastos sanguíneos realizados pelas fêmeas, mais estas se colocam na condição de potenciais vetores de doenças, sendo que, segundo Mbogo et al. (1993), vetores bem sucedidos são aqueles que se alimentam preferencialmente em humanos e secundariamente em bovinos ou animais domésticos.

A conhecida discordância gonotrófica das populações de Ae. aegypti e Cx. quinquefasciatus (FORATINI, 2002) também é um fator que poderia explicar o encontro de repastos mistos detectados pelo teste ELISA. Outro fator preponderante para que as fêmeas realizem repastos múltiplos, seria o comportamento defensivo dos hospedeiros, que podem interromper a atividade hematofágica antes que o repasto seja completado (EDMAN E SCOTT, 1987).

Os dados indicam que, embora com disponibilidade semelhante de diferentes fontes alimentares, as espécies Ae. aegypti e Cx.quinquefasciatus, coexistindo em área urbana no mesmo ambiente, todavia se distinguiram quanto ao hábito alimentar. A maior freqũência de repasto com sangue humano realizada pelas fêmeas de $A e$. aegypti era esperada pela sua antropofília e domiciliação.

O fato das espécies mencionadas no parágrafo anterior não ter se alimentado do sangue dos hospedeiros testados pela técnica, não significa que estes não tenham se alimentado em outros hospedeiros.

A despeito de não ter se verificado diferença significante em relação ao comportamento alimentar quando Ae. aegypti se alimentou: com sangue de humano e de animais, só com sangue de animais e só com sangue humano, nos três níveis sócios econômicos, a maior frequência foi verificada para o repasto com sangue humano em todos os níveis. Provavelmente as fêmeas desta espécie presentes em qualquer nível socioeconômico, tenham se alimentado durante o dia (FORATTINI, 2002) tendo acesso também ao ambiente externo. 
Já as fêmeas de $C x$. quinquefasciatus podem ter encontrado mais facilidade para obter o alimento nos domicílios dos níveis sócio econômicos mais baixos em detrimento aos mais altos, porque nestes, as medidas de proteção individual estão mais presentes, e além das pessoas estarem mais esclarecidas, possuem mais condições para adoção de medidas de proteção como a contratação empresas particulares de controle. Aparentemente como o domicílio no nível sócio econômico alto está mais protegido as fêmeas de $C x$. quinquefasciatus têm mais acesso aos animais no peridomicílio, isto poderia explicar o resultado da tabela 4, ou mesmo poderia uma tendência a buscar o sangue do animal, visto que no experimento em laboratório observou-se que a afinidade desta espécie pela membrana de tripa de boi teria sido mais atraente visto que não foi conseguida a alimentação da espécie utilizando membrana de silicone que em contrapartida alimentaram as fêmeas de Ae. aegypti. Está última espécie também se alimentou em membrana de silicone.

A diferença não significante revelada pelo teste $G$ quando se comparou a frequência de $A e$. aegypti e $C x$. quinquefasciatus no intradomicílio e no peridomicílio dos diferentes níveis sócio econômico, apesar de registros diferentes para as duas espécies nos dois habitats, (Tabelas 6 e 7), concorda com a literatura de Culicídeos que mostra que estas espécies são mais domiciliadas e antropofílicas. (FORATTINI, 1987, 2002). Estando no domicilio estas espécies frequentariam tanto 0 intra como o peridomicílio, não tendo que desperdiçar grandes energias com o vôo a procura do alimento. No intradomícilio encontram melhores condições de abrigo; mais proteção contra intempéries da natureza, e alimento.

\subsection{FONTE ALIMENTAR OBSERVADA E ASPECTOS SOCIOECONÔMICOS DAS ÁREAS E CONDIÇÕES DAS CASAS}

A maior associação, de $C x$. quinquefasciatus com sangue de galinha e de rato comparada as fêmeas de Ae. aegypti que estiveram mais associadas com sangue do homem, verificada pela análise de correspondência, pode ser uma evidência de que podendo escolher, no ambiente que oferece mais de um 
tipo de recurso alimentar, as fêmeas de Ae. aegypti buscariam mais o sangue do homem, ou seja, seriam mais antropofílicas. A maior associação de Ae. aegypti com o período de verão, com o período chuvoso e com os maiores níveis de temperatura refletem as condições favoráveis para esta espécie se desenvolver ao passo que a maior associação observada para $C x$. quinquefasciatus durante o período de inverno, e de seca. Apesar de outros estudos como o realizado por Silvério (2008) mostrarem que $C x$. quinquefasciatus é mais frequente em época chuvosa e quente, há de se considerar que a espécie se mantém por todo o ano visto que seus criadouros nos centros urbanos, na maioria das vezes, são criadouros naturais constituídos por grandes volumes de água, não dependendo das chuvas. De acordo com Morais et al. (1997) as chuvas influenciam a dinâmica desta espécie, podendo as jangadas de ovos que podem ser carreadas, por exemplo, rio abaixo, para outros criadouros ou mesmo para o solo. No período de seca os criadouros ficam altamente poluídos sendo que esta espécie é favorecida pelo acúmulo de matéria orgânica se mantendo em detrimento de outras (WALTON, 1997).

Os registros apontam que as fêmeas de Ae. aegypti se encontravam por toda a cidade assim como $C x$. quinquefasciatus. A presença de insetos adultos não esta associada aos níveis socioeconômicos apesar de que a primeira espécie está mais associada as casas em piores condições, e a segunda espécie as casas de condição considerada intermediária. Isto pode ser explicado considerando-se que o método do ICC faz o levantamento casa a zasa e não grandes áreas, levado em consideração o comportamentos dos noradores e não só as condições sanitárias e econômicas. Este aspecto pode nudar a percepção da área onde se tem maior contato com as espécies e rossivelmente o risco. Andrighetti et al. (2009), mostraram, por meio do índice e Condição de Casa, que adultos de Ae. aegypti foram capturados em casas ue necessariamente não apresentavam criadouros. As autoras encontraram $\mathrm{m}$ maior número de criadouros em casas com as piores condições. 


\subsection{ASPECTOS DA CAPACIDADE REPRODUTIVA}

\subsubsection{Fertilidade}

É importante relatar uma limitação encontrada em laboratórıo, que tol fazer a observação de postura em grupo. Dessa forma, não foi possível observar o número de fêmeas que não ovipuseram e, conseqũentemente o número exato de ovos postos por fêmeas. $O$ que foi possível foi estimar através de médias. Será interessante futuramente desenvolver estudos semelhantes com fêmeas individualizadas em borrel.

A diferença não significante verificado pelo teste Kruskall-Wallis (Figura 13) com relação a média de ovos/sobreviventes postos por fêmeas de Ae. aegypti alimentadas com sangue humano, de cão, de galinha e roedor pode indicar que o tipo de repasto não influenciou uma maior ou menor oviposição para esta espécie.

Todavia quando se observa a média de ovos postos por dia para as fêmeas desta espécie após o repastos naqueles hospedeiros, verifica-se apesar dos maiores valores de oviposição registrado entre $04^{0}$ e $6^{2}$ dia as fêmeas alimentadas com sangue humano e de cão permaneceram ovipondo até o $14^{2}$ dia, quando restavam $30 \%$ de sobreviventes, ao passo que as fêmeas alimentadas com sangue de galinha e de roedor seguiram o mesmo padrão, ou seja, paravam de ovipor no $7^{2}$ dia de observação sendo que nesse período $100 \%$ das fêmeas estavam vivas.

De qualquer forma, a média de oviposição das fêmeas de Ae. aegypti, alimentadas com os diferentes hospedeiros aqui testados, também pode ser indício de que o tipo de repasto não alteraria o "perfil" do ciclo gonotrófico visto que os maiores picos de oviposição foram verificados entre $04^{2}$ e $6^{9}$ dia independente do tipo de repasto.

O tamanho do ciclo gonotrófico, associado à longevidade da espécie pode indicar a sua maior ou menor importância epidemiológica, quanto menor 0 ciclo gonotrófico entende-se que a fêmea irá procurar novo hospedeiro para repasto, aumentando o risco em caso de transmissão (FORATTINI, 2002). 
Também chama atenção a diferença não significante observada entre as médias de ovos postos por fêmeas de $C x$. quinquefasciatus em detrimento a valores mais altos para oviposição observada para as fêmeas que fizeram repasto com sangue de roedor e galinha (Figura 18) desconsiderando os dias de observação. Também observou-se que o padrão de média de ovos postos no decorrer dos dias foi semelhante. A maior parte dos ovos foram postos entre o $3^{2}$ e $7^{9}$ dia.

Os resultados indicaram que as fêmeas de $C x$. quinquefasciatus foram mais férteis realizando repasto em sangue de roedor quando comparado as que se alimentaram de sangue de cão e humano. A variação na média máxima de ovos postos por fêmea foi de 18 e 72 respectivamente para sangue de cão e roedor (Figura 18). Aparentemente estas fêmeas estão tão adaptadas ao sangue do roedor quanto ao sangue humano e do cão. Pelo menos na natureza dos habitats urbanos existe à proximidade do nicho trófico, sangue do roedor, com os nichos espaciais, representados pelos criadouros, contendo águas servidas, esgotos, e abrigos, como as galerias de esgoto, portanto acredita-se que a espécie esteja bem adaptada a este tipo de repasto sanguíneo. Quanto à utilização do sangue do cão com posterior oviposição era esperado, visto que o cão, animal domesticado, ocupa o peridomícilio ou mesmo o intradomicílio humano. Todavia levanta-se a hipótese de que a qualidade do repasto sanguíneo pudesse ter influência sobre a taxa ou percentual de oviposição.

\subsubsection{Tempo de Desenvolvimento}

A estimativa de tempo de desenvolvimento neste trabalho foi baseada em percentual de pupas emergidas, considerando que esta fase do desenvolvimento dos Culicidae representaria melhor a chance de produzir formas adultas (FOCKS E CHADEE, 1997; FOCKS, 2002).

É sabido que na natureza um conjunto de variáveis abióticas no criadouro, como por exemplo, temperatura, disponibilidade de alimento, presença de sais, competição, predação, entre outros (URBINATTI, 2001, 
FORATTINI, 2002) controlam o desenvolvimento dos estádios larvais até chegarem a o estágio de pupa. Em laboratório onde as condições foram ideais, estas variáveis foram controladas Outras, como as que poderiam acelerar ou retardar o processo de desenvolvimento das larvas, não existiram, portanto acredita-se que o único repasto sanguíneo recebido pelas fêmeas de $A e$. aegypti e $C x$. quinquefasciatus, poderiam de certa forma ter alterado o tempo de desenvolvimento dos ovos e estádios larvais até o estágio de pupa.

Aparentemente os resultados indicam que, a função dos dias de desenvolvimento das larvas de Ae. aegypti, provenientes de ovos fêmeas alimentadas com sangue de cão, torna mais rápido o desenvolvimento destas até chegarem ao estágio de pupa. Isto é verificado pelo modelo de regressão univariada que explicou $84 \%$ da variação dos dias de desenvolvimento em relação à produção de pupas. A Figura 25 mostra que ao longo do período de desenvolvimento há no início um ápice de produção de pupas seguida de queda acentuada.

Em contrapartida foi observado para as fêmeas Ae. aegypti que foram alimentadas com sangue de galinha que a curva da regressão apresentou-se de forma ascendente, ou seja, o maior percentual de pupação aconteceu mais vagarosamente, ao longo dos dias de desenvolvimento. A despeito do modelo não ter sido considerado bom, pelo valor da distribuição de $(F=0.4715 ; p=$ $0.5151)$, e por apenas $5 \%$ da variação dos dias de desenvolvimento explicar o percentual de pupas desenvolvidos $\left(R^{2}=0,05\right)$, o coeficiente de correlação de Pearson indicou $22 \%$ de correlação positiva para as variáveis.

Também não foi bom, o modelo que explicou a função dos dias de desenvolvimento das larvas, provenientes de ovos fêmeas de Ae. aegypti alimentadas com sangue humano, até chegar a pupa. Contudo $28 \%$ de correlação positiva foi observada para as variáveis em questão. $\mathrm{E}$, apesar de apresentar curva descendente o ápice para a produção de pupas ocorreu entre o $7^{9}$ e o $10^{9}$ dias de desenvolvimento.

A relação observada no campo de que sangue de cão foi o segundo mais utilizado por fêmeas de Ae. aegypti foi constatada também em laboratório. Aparentemente o sangue humano torna mais rápido o desenvolvimento dos 
ovos até o estágio de pupa comparado com o os ovos de fêmeas alimentadas de galinha, roedor e cão. Esse sangue parece propiciar um percentual maior de pupação até o $10^{\circ}$ dia do desenvolvimento, depois disso a queda da curva de regressão foi mais acentuada.

Quando se analisou o decorrer dos dias de desenvolvimento das larvas provenientes de ovos fêmeas de Ae. aegypti alimentadas com sangue humano, de cão e galinha em um único modelo, multivariado, este foi bom, muito provavelmente teria sido ajustado pelo modelo univariado que explicou a função dos dias de desenvolvimento das larvas provenientes de fêmeas alimentadas com sangue de cão.

A investigação da variação dos dias de desenvolvimento para as larvas de $C x$. quinquefasciatus, até chegarem ao estágio de pupa, cujos ovos são provenientes de fêmeas alimentadas uma única vez com sangue, humano, de cão, de galinha e roedor, mostrou que a função dos dias de desenvolvimento das larvas, desta espécie em função do percentual de pupação, provenientes de larvas oriundas de ovos de fêmeas que se alimentaram uma única vez com sangue de cão, foi a que melhor explicou, com 93\%, o modelo de regressão que foi bom $\left(\beta_{1} \neq z e r o\right)$ e significante $(p<0,05)$. As variáveis estiveram correlacionadas em $97 \%(r=0.97)$, contudo as pupas provenientes de larvas oriundas de ovos das fêmeas que se alimentaram com sangue de galinha e roedor, cujos modelos não foram bons e tão pouco significantes, apresentarão baixa correlação entre as variáveis. Aparentemente as larvas, provenientes de ovos oriundos das fêmeas de $C x$. quinquefasciatus, alimentadas com estes repastos, levaram mais dias até chegarem a pupação.

O sangue humano aparentemente também teria favorecido o rápido desenvolvimento das lanvas de $C x$. quinquefasciatus, visto que a função dos dias de desenvolvimento em relação ao percentual de pupação foi explicado em $62 \%$.

Todos os dados apresentados apontam para a necessidade do aprofundamento da caracterização e determinantes do hábito alimentar de culicídeos. Os mesmos podem contribuir para reorientação das estratégias de 
controle das doenças veiculadas por esses insetos, assim como entender a participação de diversos animais no ciclo de transmissão. 


\section{CONCLUSÕES}

- O perfil hematofágico das espécies coletadas mais abundantes foi diferente, considerando os parâmetros estudados, sendo que $C x$. quinquefasciatus se mostrou mais eclético do que Ae. aegypti.

- Ambas as espécies realizam repastos múltiplos, embora essa não tenha sido a característica predominante, visto que a maior proporção foi de repastos únicos.

- Os aspectos socioeconômicos não influenciaram a busca pela fonte alimentar em Ae. aegypti, diferente do $C x$. quinquefasciatus, que apresentou maior proporção de repasto não humanos em área de maior nível socioeconômico.

- Houve associação entre clima e a presença das espécies, sendo Ae. aegypti associado ao período chuvoso e de altas temperaturas, e o Cx. quinquefasciatus associado à baixa pluviosidade, o que deve estar relacionado à disponibilidade de criadouros característicos de cada uma das espécies. Não foi encontrada associação entre fonte alimentar e condição climática.

- Em relação à fonte alimentar, não houve diferenças significantes no número de ovos postos para as duas espécies estudadas. No entanto, esta parece ter influenciado o período de desenvolvimento.

O estudo traz novos conhecimentos sobre o hábito alimentar, no entanto carece de aprofundamento para que se possa entender o significado dessas diferenças na determinação da capacidade vetorial. 


\section{REFERÊNCIAS BIBLIOGRÁFICAS}

Altman DG. Practical statistics for medical research. Boca Raton: Chapman \& Hall/CRC. 1999.

Alves LB, Belderrain MCN, Scarpel RA. Tratamento multivariado de dados por análise de correspondência e análise de agrupamentos. Anais $13^{2}$ Encontro de Iniciação Científica e Pós-Graduação do ITA, São José dos Campos, SP, Brasil, outubro, 2007.

Andrighetti MTM, Galvani KC, Macoris MLG. Evaluation of premise condition index in the context of Aedesaegypti control in Marília, São Paulo, Brazil.Dengue Bulletin. 2009; 33:167-175.

Barcellos C, Bastos Fl. Geoprocessamento, ambiente e saúde: uma união possível? Caderno de Saúde Pública. 1996; 12(3):389-397.

Beier JC, Perkins PV, Wirtz RA, Koros J, Diggs D, Gargan TP, Koech DK. Bloodmeal Identification by Direct Enzyme-Linked Immunosorbent Assay (ELISA), Tested on Anopheles (Diptera: Culicidae) in Kenya. J MedEntomol. 1988; 25(1):9-16.

Benzecri, JP. Statistical analysis as a tool to make patterns emerge from data. In: Watanabe, S. (ed.). Methodologies of Pattern Recognition.New York, Academic Press; 1969.p.35-74

Boreham PFL. Serological identification of arthropod bloodmeals and its application.PANS.1972; 18:205. 
Burkot TR, Goodman WG, DeFoliart GR. Identification of Mosquito Blood Meals by Enzyme-Linked Immunosorbent Assay. Am J TropMedHyg. 1981; 30(6):13361341.

Camargo-Neves VLF, Rodas LAC,Gomes AC. Avaliação do hábito alimentar de Lutzomyia longipalpis no Estado de São Paulo. BEPA. 2007; 39(4):04-09.

Clark GG, Seda H, Gubler DJ. User of the "CDC backpack aspirator" for surveillance of Aedes aegypti in San Juan, Puerto Rico. J Am Mosq Control Assoc. 1994; 10: 119-24.

Castex M, Suarez E, Marquetti MC. Food Sources of Cx.quinquefasciatus Say, 1823 (DipteraCulicidae) in Machurrucutu Locality, Havana Province, Cuba.Research Note.Mem.Inst. Oswaldo Cruz. 1990; 85(2): 241-242.

Chadee DD, Beier JC. Natural variation in blood feeding kinetics of four mosquito vectors. J. Vector Ecol. 1996; 21: 151-156.

Chow E, Wirtz RA, Scott TW. Identification of blood meals in Aedesaegypti by antibody sandwich enzyme-linked immunosorbent assay.J AmerMosqControl Assoc. 1993; 9:195-205.

Consoli RAGB, Lourenço-de-Oliveira R. Principais Mosquitos de Importância Sanitária no Brasil. Rio de Janeiro: Editora Fiocruz; 1994. 
Daniel TL, Kingsolver JG. Feeding Strategy and the Mechanics of Blood Sucking in Insects.J Theor Biol. 1983; 105: 661-672.

Edman JD, Scott TW. Host defensive behavior and the feeding success of mosquitoes.Insect SciAppll.1987; 8: 617-22.

Edman JD. Fitness advantages in multiple blood-feeding: the Ae. aegypti example.In:Ecological Aspects for Application of Genetically Modified Mosquitoes. Ed. Kluwer Academic Publishers. 2003; 244(2): 63-74.

Edrissian GH, Manouchehry AV, Hafizi A. Application of enzyme-linked immunosorbent assay (ELISA) to identification of Anopheles mosquito bloodmeals.Trans $R$ Soc Trop Med Hyg. 1982; 76(1): 54-56.

Edrissian GH, Manouchehry AV, Hafizi A. Application of an enzyme-linked immunossorbent assay (ELISA) for determination of the human blood index in anopheline mosquitoes collected in Iran. J AmMosqControl Assoc. 1985; 1(3): 349-52.

Engvall E, Perlmann P. Enzyme-linked immunosorbent assay (ELISA). Quantitative assay of immunoglobulin G. Immunochemistry. 1971; 8(9): 871-4.

Ferreira W, Ávila SLM. Diagnóstico Laboratorial das Principais Doenças Infecciosas e Auto-Imunes. 2a ed, Rio de Janeiro: Guanabara - Koogan; 2001.

Focks DA, Chadee, A review of entomological sampling methods and indicators for dengue vectos. Document n. TDR/IDE/ Den/03.1. Geneva: World Health Organization, 2002. 
Focks DA, Chadee, DD. Pupal Survey: An Epidemiologically Significant Surveillance Method for Aedesaegypti: An Example Using Data from Trinidad. Am. J. Trop. Med. Hyg. 1997; 56(2): 159-167.

Forattini OP, Gomes AC, Santos JLF, Galati EAB, Rabello EX, Natal D. Observações sobre a atividade de mosquitos Culicidae em mata residual no Vale do Ribeira, São Paulo, Brasil. Rev Saúde Pública. 1981; 15: 557-86.

Forattini OP, Gomes AC, Natal D, Kakitani I, Marucci D. Preferências alimentares de mosquitos Culicidae no Vale do Ribeira, São Paulo, Brasil. Rev Saúde Pública. 1987; 21(3): 171-87.

Forattini OP, Gomes AC, Natal D, Kakitani I, Marucci D. Preferências alimentares e domiciliação de mosquitos Culicidae no Vale do Ribeira, São Paulo, Brasil, com especial referência a Aedes scapularis e a Culex (Melanoconion).Rev Saúde Pública. 1989; 23: 9-19.

Forattini, OP. Culicidologia Médica v.2. São Paulo: Ed. USP; 2002.

Gentile LF, Marques MC. Caracterização das nascentes urbanas no município de Marília: situação em 2009. São Paulo; 2009. [Monografia - Programa de Especialização em Questão Ambiental e as Transformações no Território Brasileiro da FCT/UNESP]

Gillies MT. The recognition of age-groups within populations of Anopheles gambiae by the pre-gravid rate and the sporozoite rate.Ann Trop Med Parasitol.1954; 48: 5874. 
Gillies MT. The pre-gravid phase of ovarian development in Anopheles funestus.Ann TropMedParasitol. 1955; 49: 320-5.

Godoy H, Ortolani AA. Carta climática do Estado de São Paulo. Campinas: Instituto Agronômico, Seção de Climatologia Agrícola; 1965.

Gomes AC, Silva NN, Marques GRAM, Brito M. Host-feeding patterns of potential human disease vectors in the Paraíba Valley region, State of São Paulo, Brazil. J Vector Ecol. 2003; 28: 74-8.

Haouas N, Gorcii M, Chargui N, Aoun K, Bouratbine A, Messaadi Akrout F et al. Leishmaniasis in central and southern Tunisia: current geographical distribution $f$ zymodemes. Parasite. 2007; 14: 239-246.

Harrington LC, Edman JD and Scott TW. Why do female Ae.aegypti (Diptera:Culicidae) feed preferentially and frequently on human blood? J. Med. Entomol. 2001; 38(3): 411-422.

Hervé JP, Rosa APAT. Ecologia da febre amarela no Brasil. Fundação SESP. 1983; 28: 11-9.

Kelly DW. Why are some people bitten more than others? Trends in Parasitology. $1981 ; 17(12): 578-581$.

Kent RJ, Norris DE. Identification of mammalian blood meal in mosquitoes by a multiplexed polymerase chain reaction targeting cytochrome b. Am. J. Trop. Med. Hyg. 2005; 73(2): 336-342. 
Linthicum KJ, Davies FG, Kairo A, Bailey CL. Rift Valley fever virus (family Bunyavirdae, genus Phlebovirus). Isolations from Diptera collected during an inter-epizootic period in Kenya. J Hyg (Cambridge). 1985; 95: 197-209.

Lourenço-de-Oliveira R, Heiden R. Alguns aspectos da ecologia dos mosquitos (Diptera:Culicidae) de uma área de planície (Granjas Calábria) em Jacarepaguá, Rio de Janeiro. IV. Preferências alimentares quanto ao hospedeiro e freqũência domiciliar. Mem Inst Oswaldo Cruz. 1986; 81: 15-27.

Mbogo CNM, Kabiru EW, Muiruri SK, Nzovu JM, Ouma IG, Beier JC. Bloodfeeding behavior of Anopheles gambiae S.L. and Anopheles funestus in Kilifi district, Kenya. J AmMosqCont Assoc. 1993; 9: 225-27.

Mitchell CJ, Monath TP, Sabattini MS, Christensen HA, Darsie RF, Jakob WL et al. Host-feedind patterns of Argentine mosquitoes (Diptera: Culicidae) collected during and after an epizootic of western equine encephalitis. J Med Entomol. 1987; 24: 260-7.

Morais AS, Marrelli MT, Natal D. Aspectos da distribuição de Culex (Culex) quinquefasciatusSay (Diptera, Culicidae) na região do rio Pinheiros, na cidade de são Paulo, Estado de São Paulo, Brasil. Rev Bras Entomol. 2006; 50(3): 41318.

Nasci RS.A light weight battery powered aspirator for collecting resting mosquitoes in the field. Mosq News. 1981; 41: 808-11.

Natal D, Ueno HM. Vírus do Nilo Ocidental: Características da Transmissão e Implicações Vetoras. Entomol Vect. 2004; 11(3): 417-433. 
Niebylski ML, Savage HM, Nasci RS, Craig Jr GB. Blood Hosts of Ae.albopictus in the United States. J Am Mosq Control Assoc. 1994; 10(3): 447-50.

Rocha EMM, Fontes G. Filariose bancroftiana no Brasil. Rev. Saúde Pública. 1998; 32: 98-105.

Rurangirwa FR, Minja SH, Musoke AJ, Nantulya VM, Grootenhuis J, Moloo SK. Production and evaluation of specific antisera against sera of various vertebrate species for identification of bloodmeals of Glossina morsitans centralis. Acta Trop. 1986; 43: 379-389.

Santos M. Espaço e Método. $4^{\text {ed. }}$ edão Paulo: Nobel; 1997.

Scott TW, Chow, Strickman E, Kittayapong P, Wirtz RA, Lorenz LH, Edman JD. Blood feeding patterns of Ae.aegypti(Diptera: Culicidae) during a single gonotrophic cycle using a histological technique. J. Med. Entomol. 1993; 30: 922-927.

Scott TW, Amerasinghe PH, Morrison AC, Lorenz LH, Clark GG, Strickman D, Kittayapong $\mathrm{P}, \quad$ Edman JD. Longitudinal studies of $\mathbf{A e}$. aegypti(Diptera:Culicidae) in Thailand and Puerto Rico: Blood Feeding Frequency. J. Med. Entomol. 2000; 37(1): 89-101.

Service MW, Voller A, Bidwell DE. The enzyme-linked immunosorbent assay (ELISA) test for the identification of bloodmeals of haematophagous insects.Bull Ent Res. 1986; 76: 321-30.

Silvério EC. Estudo da fauna de mosquitos (Diptera: Culicidae) em reservatórios de contenção de cheias em área metropolitana da cidade de São Paulo, SP. 
[dissertação de mestrado]. São Paulo: Faculdade de Saúde Pública da Universidade de São Paulo; 2008.

Tempelis $\mathrm{CH}$. Review article host-feeding patterns of mosquitoes, with a review of advances in analysis of blood meals by serology. J. Med. Entomol. 1975; 11: $635-653$

Tun-Lin W, Kay BH, Barnes A. The premisse condition index: A tool for streamlining surveys of Aedes aegypti. Am. J. Trop. Med. Hyg. 1995; 53: 591-594.

Urbinatti PR, Sendacz S, Natal D. Imaturos de mosquitos (Diptera: Culicidae) em parque de área metropolitana aberto à visitação pública. Rev Saúde Pública. 2001; 35(5): 461-6.

Vicentin EC. Identificação do sangue ingerido, utilizando a técnica de ELISA, por fêmeas de Ae. scapularis do Parque Ecológico do Tietê, São Paulo, Estado de São Paulo [dissertação de mestrado]. São Paulo: Faculdade de Saúde Pública da Universidade de São Paulo; 2007.

Voller A, Bidwell D, Huldt G, Engvall E. A microplate method of enzyme-linked immunosorbent assay and its application to malaria. Bull World Health Organ. 1974; 51: 209-211.

Walton WE, Workman PD, Offill AY, Randall LA, Jiannino JA. Influence of vegetation on mosquito prodution from a constructed wetland. In: March $\mathrm{J}$, ed. Mosquito control research: annual report. California: University of California: Division of agriculture and natural resources. 1997; 55-60. 
Weitz B. Identification of bloodmeals of blood sucking arthropods. Bull. WHO 1956; 15: 473-90.

Ximenes RAA, Martelli CMT, Lapa TM, Albuquerque MFM, Andrade ALSS, MoraisNeto OL, Silva AS, Lima MLC, Portugal JL. Vigilância de doenças endêmicas em áreas urbanas: a interface entre mapas de setores censitários e indicadores de morbidade. Cad Saúde Pública. 1999; 15(1): 53-61. 
ANEXOS 


\section{Anexo 1 - Lista de Reagentes utilizados no teste ELISA}

- Anti-soro de humano: Affinity Purified Antibody to Human $\lg G(\mathrm{H}+\mathrm{L})$, produced in goat, KPL - Kirkegaard \& Perry Laboratories, Inc., Gaithersburg, Md.;

- Anti-soro de galinha: Affinity Purified Antibody to Chicken $\lg G(H+L)$, produced in goat, KPL - Kirkegaard \& Perry Laboratories, Inc., Gaithersburg, Md.;

- Anti-soro de cão: Affinity Purified Antibody to Dog $\operatorname{lgG}(\mathrm{H}+\mathrm{L})$, produced in goat, $\mathrm{KPL}$ Kirkegaard \& Perry Laboratories, Inc., Gaithersburg, Md.;

- Anti-soro de rato: Affinity Purified Antibody to Rat IgG $(\mathrm{H}+\mathrm{L})$, produced in goat, $K P L-$ Kirkegaard \& Perry Laboratories, Inc., Gaithersburg, Md.;

- Conjugado peroxidase anti-humano: Peroxidase-Labeled Affinity Purified Antibody to Human IgG $(\mathrm{H}+\mathrm{L})$, produced in goat, KPL-Kirkegaard \& Perry Laboratories, Inc., Gaithersburg, Md.;

- Conjugado peroxidase anti-galinha: Peroxidase-Labeled Affinity Purified Antibody to Chicken IgG $(\mathrm{H}+\mathrm{L})$, produced in goat, KPL-Kirkegaard \& Perry Laboratories, Inc., Gaithersburg, Md.;

- Conjugado peroxidase anti-cão: Peroxidase-Labeled Affinity Purified Antibody to Dog IgG $(\mathrm{H}+\mathrm{L})$, produced in, LPL-Kirkegaard\&Perry Laboratories, Inc., Gaithersburg, Md.;

- Conjugado peroxidase anti-rato: Peroxidase-Labeled Affinity Purified Antibody to Rat IgG $(\mathrm{H}+\mathrm{L})$, produced in goat, KPL-Kirkegaard\&Perry Laboratories, Inc., Gaithersburg, Md;

- Glicerol - Sigma G-7893;

- ABTS - Substrate Solution A 450ml (code 50-64-02), KPL-Kirkegaard \& Perry Laboratories, Inc., Gaithersburg, Md;

- ABTS - Substrate Solution B 450ml (code 50-65-02), KPL-Kirkegaard \& Perry Laboratories, Inc., Gaithersburg, Md;

- PBS - Solution Buffer Phosphate (0,15 M) pH 7,2 ( $\mathrm{NaCl}, \mathrm{NaH}_{2} \mathrm{PO}_{4}+\mathrm{H}_{2} \mathrm{O}, \mathrm{Na}_{2} \mathrm{HPO}_{4}-$ MERCK);

- Tween 20 - Polyoxyethylene Sorbitan Monolaurase, Sigma, P-1379;

- Leite desnatado Molico ${ }^{\circledast}$, Nestlé.

- Placas $\operatorname{COSTAR}^{\circledast 2}$ 2797, Cambridge,MA 
Anexo 2 - Número de fêmeas capturadas por coleta e espécie entre o período de junho de 2007 a abril de 2009. Marília/SP.

\begin{tabular}{|c|c|c|c|c|c|c|c|c|}
\hline \multirow{2}{*}{$\begin{array}{l}\text { No da } \\
\text { coleta }\end{array}$} & \multicolumn{2}{|c|}{ Data da coleta } & \multicolumn{2}{|c|}{ № Amostras } & \multicolumn{4}{|c|}{ Número de fémeas capturadas por espécie } \\
\hline & Ínicio & Fim & Peri & Intra & $\begin{array}{l}\text { Ae. } \\
\text { aegypti }\end{array}$ & $\begin{array}{l}\text { Ae. } \\
\text { albopictus }\end{array}$ & $\begin{array}{l}\text { Ae. } \\
\text { scapularis }\end{array}$ & $\begin{array}{l}x \\
\text { quinquefasciatus }\end{array}$ \\
\hline 1 & $19 / 06 / 2007$ & $13 / 07007$ & 6 & 135 & 16 & 0 & 1 & 124 \\
\hline 2 & 23/08/2007 & $14 / 09 / 2007$ & 24 & 238 & 0 & 0 & 1 & 261 \\
\hline 3 & 22/10/2007 & 20/11/2007 & 27 & 91 & 14 & 0 & 1 & 103 \\
\hline 4 & $17 / 12 / 2007$ & 21/01/2008 & 38 & 68 & 60 & 0 & 2 & 44 \\
\hline 5 & $18 / 02 / 2008$ & $23 / 04 / 2008$ & 11 & 50 & 48 & 0 & 1 & 12 \\
\hline 6 & $19 / 05 / 2008$ & $19 / 06 / 2008$ & 3 & 20 & 18 & 1 & 0 & 4 \\
\hline 7 & $28 / 07 / 2008$ & $25 / 08 / 2008$ & 0 & 31 & 15 & 0 & 1 & 15 \\
\hline 8 & $10 / 09 / 2008$ & $13 / 03 / 2008$ & 5 & 46 & 16 & 0 & 0 & 35 \\
\hline 9 & $24 / 11 / 2008$ & $23 / 12 / 2008$ & 8 & 38 & 17 & 0 & 0 & 29 \\
\hline 10 & $19 / 01 / 2009$ & $27 / 02 / 2009$ & 14 & 36 & 28 & 1 & 5 & 16 \\
\hline 11 & 09/03/2009 & $09 / 04 / 2009$ & 4 & 18 & 21 & 0 & 0 & 1 \\
\hline 12 & $13 / 04 / 2009$ & $16 / 04 / 2009$ & 1 & 5 & 3 & 0 & 0 & 3 \\
\hline TOTAL & & & 141 & 776 & 256 & 2 & 12 & 647 \\
\hline
\end{tabular}




\section{Curriculum Lattes}

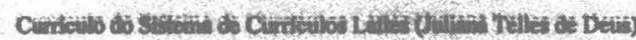

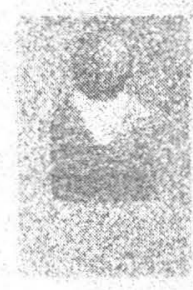

Juliana Telies de Douse-

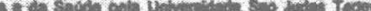

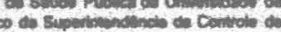

ren 4 -

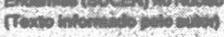

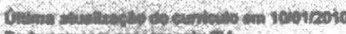

som

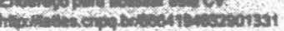

Descos onseonte

Noms rilene renes de bese

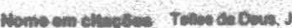

Blbllogrthes

susco Fintatio

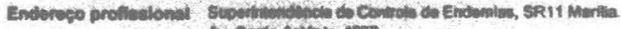

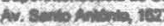

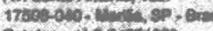

Telowe (19 Jesorced.

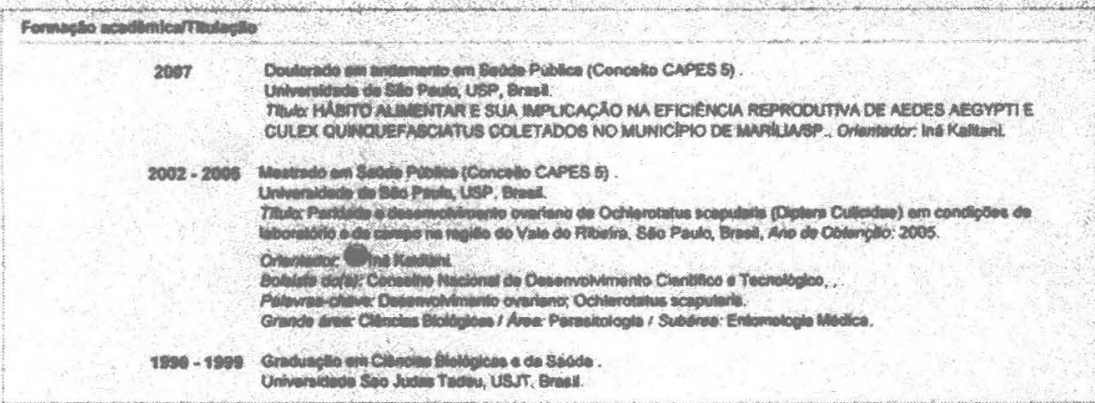

Formectio comptenenter

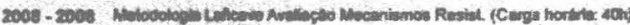

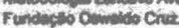

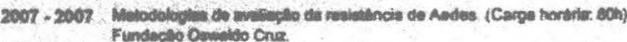

$2002-2002$ Gurso do Cuna buncilo

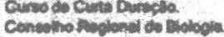

$2002 \cdot 2002$ Curso do Cume Duracto.

Coneche

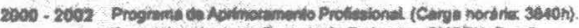

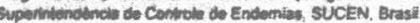

$2001-2001$ Cano de Curta Dursplo.

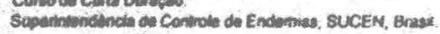

1999 - 1999 Canso do Curt Duresto

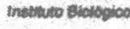

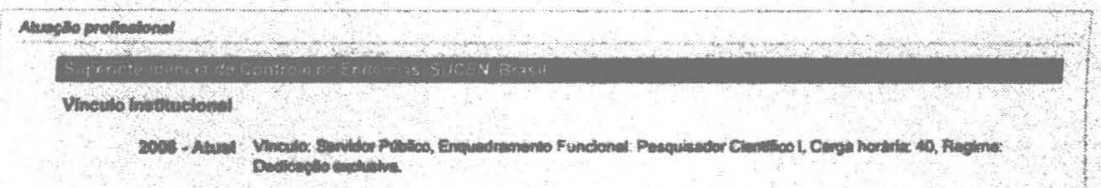

hilp

2upinoit co:12:12 


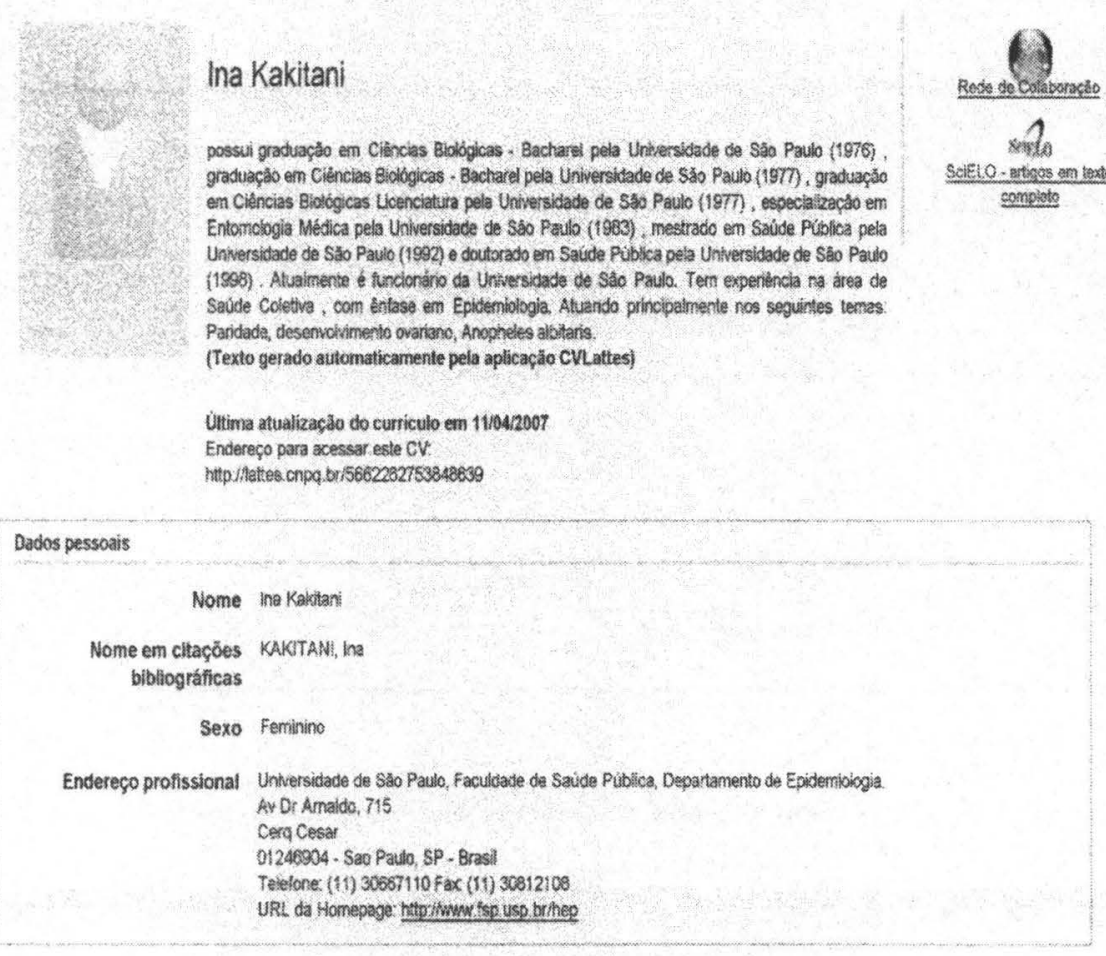

Fornação acadênica/Titulaçăło

1993 - 1998 Doutorado em Saide Pública (Concelo CAPES 5). Universidade de Săo Paulo, USP, Brasil

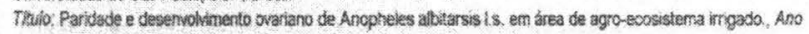
ชe Obtençẵa: 1998

Onentador. Oswaido Peulo Foratini.

Palawras-chave: Paridade, desenwotimento ovariano, Anopheles altitaris

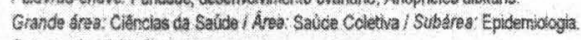
Setores de ativicade : Outro.

1983 - 1992 Mestrado em Saúde Púbica (Cancento CAPES 5)

Universidade de Säo Paulo USP, Brasil.

Thio: Observaçes prelininares sobre a paridade de Anopheles (Kerteszia) cruz. Ano de Obtançåc: 1992 Orientactor. Almério de Castro Gomes

Boisista doy al: Conselho Nacional de Desenvolvinento Cientifico e Tecnobicon.

Palavras chave: Paridade, Aropheles.

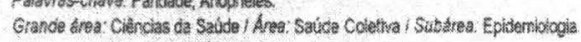
Setores de atvidade: Outro.

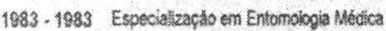

Universidade de Săo Paulo, USP, Eress

1971 - 1977 Graduaçăo em Ciências Biblogicas - Bacharsi Unwersidade de Sảo Paulo, USP, Brasi 